\title{
Design and Synthesis of a Highly Simplified Pateamine Analogue
}

Sarah Louisa Brown

\begin{abstract}
A thesis submitted to Victoria University of Wellington in partial fulfilment of the requirements for the degree of Masters in Biomedical Science
\end{abstract}




\section{ABSTRACT}

Pateamine (1) is a natural product from the marine sponge Mycale hentscheli that exhibits potent anticancer properties, and has potential as an antiviral agent, and in preventing the muscle wasting disorder cachexia. This biological activity of pateamine is due to its ability to inhibit the eukaryotic initiation factor elF4A, which leads to the formation of stress granules, the inhibition of protein synthesis, and ultimately cell death. Unfortunately, pateamine is obtained in very small amounts from Mycale hentscheli; thus, it is necessary to synthesise pateamine and novel structural analogues in the laboratory. Previously a separate binding and scaffolding domain of pateamine was proposed, which led to the synthesis of a simplified des-methyl desamino analogue that reduced the number of synthetic steps compared to pateamine while retaining its biological activity. This was followed by the synthesis of a simplified triazolecontaining analogue 96; unfortunately, this exhibited substantially reduced bioactivity compared to pateamine, and it is therefore necessary to determine if the reduction in bioactivity was due to the replacement of the thiazole ring with a triazole ring, or due to the removal of key methyl groups of pateamine. Thus, the thiazole-containing analogue of 96 is deemed to be an important synthetic target.

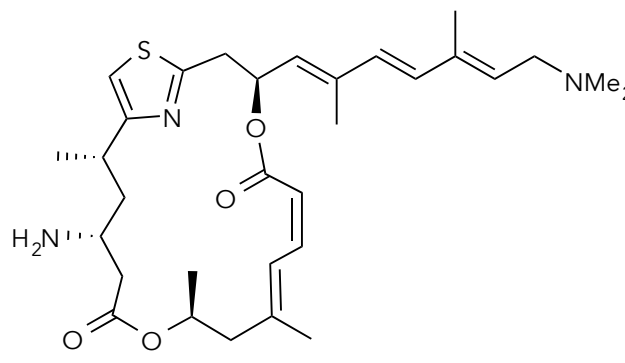

Pateamine, 1

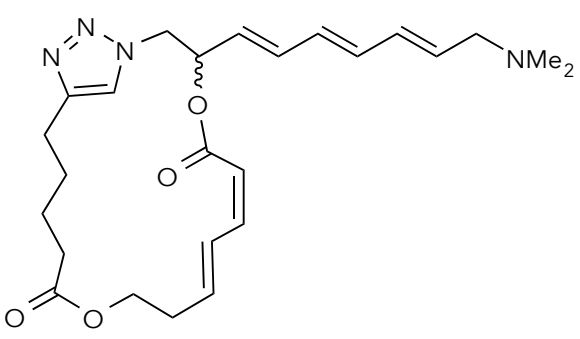

96

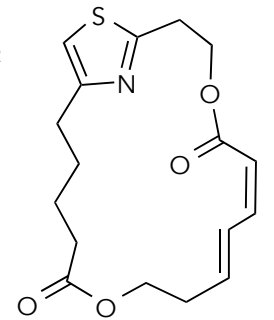

130

In this Master's project a highly simplified side chain-free analogue 130 was synthesised, which laid the groundwork for future synthesis of a thiazole-containing analogue of 96 . The synthesis of 130 was achieved through a convergent synthesis with one commercially available and two prepared fragments. Particular attention was paid to the development of an efficient thiazole formation methodology, as well as optimising fragment synthesis and coupling reactions. Determination of the binding of analogue 130 with elF4A using a competitive bioactivity assay in the presence of pateamine was then undertaken, which showed that either 130 does not bind to elF4A or that it binds non-covalently and is then displaced by pateamine. 


\section{ACKNOWLEDGEMENTS}

While these past few years have been hard, they have also been the most enjoyable and enriching, I have learnt and accomplished so much, and have made many friends on the way. So without sounding too corny, I would like to thank the people who have helped me succeed.

Firstly I'd like to thank to my two supervisors, Paul Teesdale-Spittle and Joanne Harvey. Thank you Paul for your enthusiasm, keeping your office door open for me, for giving me helpful suggestions, looking through my spectra, results and drafts many times - even when you had more important things to do! Joanne thanks for all the helpful input, making time for me, and always being so enthusiastic about my project!

To Brad, I probably wouldn't have done Master's if it weren't for you, and I definitely wouldn't have been able to finish if you weren't by my side! Thanks for all the support, driving me to uni on the weekends and picking me up late at night, proofreading my "dry" thesis, and teaching me how to properly use a semicolon.

To my friends, thanks for all the coffee dates, listening to me talk/complain about my project, and sticking with me; especially Kris and Loïc, but also Joe, Ethan, Siobhan, Claire, Lucy, Harley, Adam, Allan, Duke, Chloe, and India. To my family, thank you for supporting me and having faith in me succeeding my goals!

To all the Eastenders past and present - Jingjing, Kalpani, Thomas, Sophie, Amira, Matt, Dan, Chris, Hedley, Tao, Claire, José Luis, Ben and Helena, thanks for all your help in the lab and making the lab such a fun place! Also a big thanks to Hemi, for helping me out at the start of my project, and contributing so much to the synthesis of pateamine analogues.

Thanks to all the biologists - Vimal for helping me out with all my calculations, cell culture and MTT assays, Rishi for teaching me how to grow my cells, Richard for giving me some of your precious pateamine to work on, and Matt for making my awesome graphs. To the rest of the spaceship - Pirooz, Georgia and Nikki, thanks for all the fun times in the office. Thanks to everyone else in SCPS and SBS for helping out and making this a great work environment. Special thanks to lan for looking after the NMR and MS machines and helping me out with them. Finally to everyone reading this thesis, I hope you enjoy the read! 


\section{TABLE OF CONTENTS}

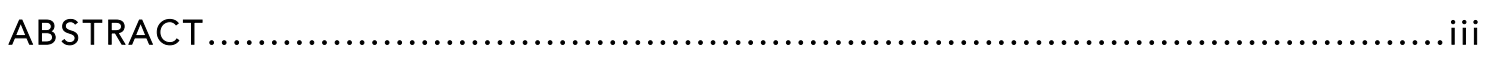

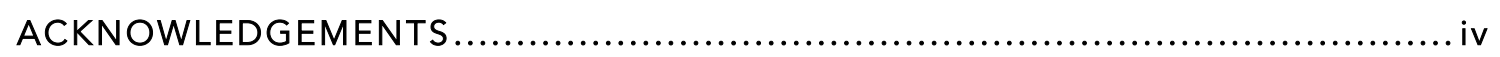

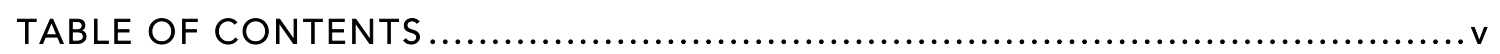

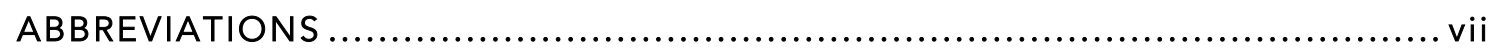

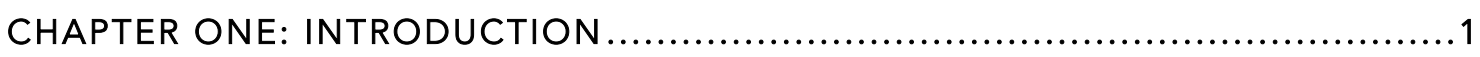

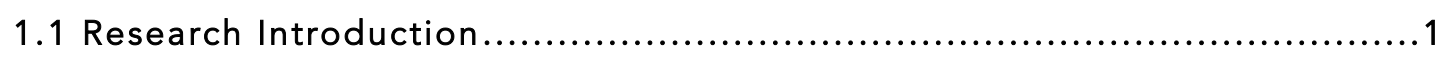

1.2 Natural Products and Analogues in Drug Discovery .........................

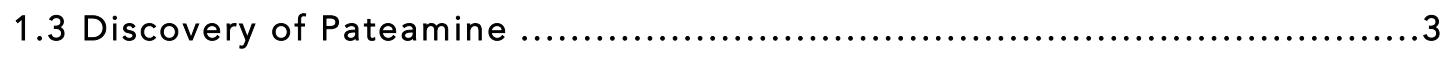

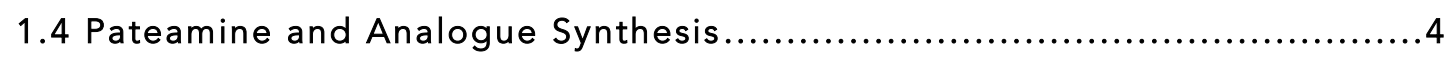

1.4.1 Total Synthesis of Pateamine by Romo ....................................................... 5

1.4.2 Total Synthesis of Pateamine by Pattenden .............................................. 9

1.4.3 First Generation Analogues Prepared by Romo.............................................. 13

1.4.4 Second Generation Analogues Prepared by Romo ......................................... 17

1.4.5 Simplified Triazole-Containing Analogue Prepared by Cumming ........................ 19

1.5 Biological Activity of Pateamine and Analogues ...........................26

1.5.1 Initial Biological Studies of Pateamine and Analogues ....................................... 26

1.5.2 Discovery of the Biological Target of Pateamine ......................................... 27

1.5.3 Role of elF4A and Inhibition of elF4A by Pateamine .................................... 28

1.5.4 Potential Therapeutic Benefits of Pateamine ................................................ 29

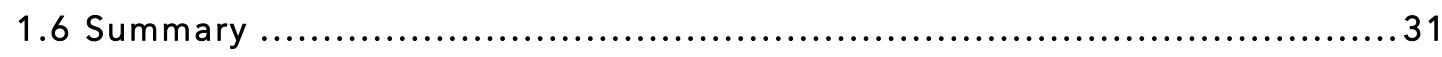

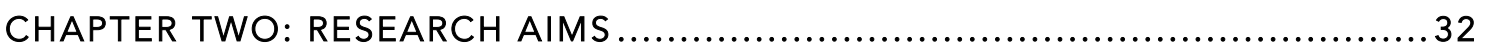

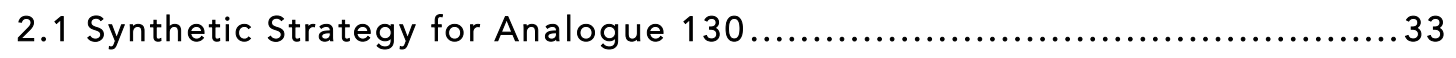

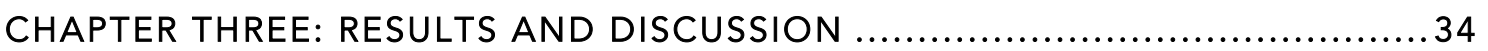

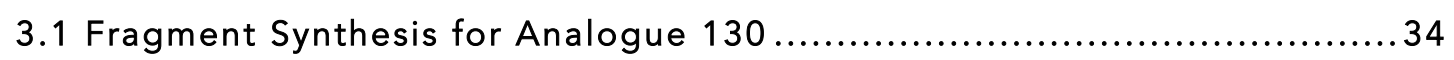

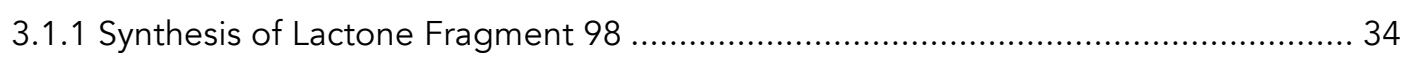

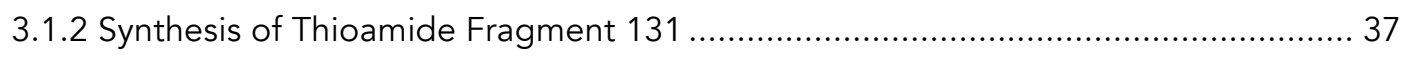

3.2 Fragment Coupling and Completion of the Synthesis of Analogue $130 \ldots 39$

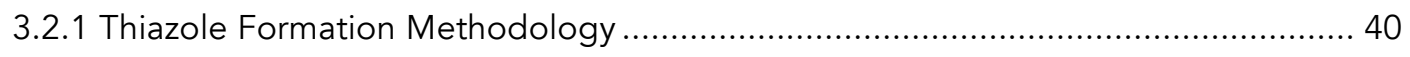

3.2.2 Model Thiazole Formation Reactions ......................................................... 42

3.2.3 Thiazole Formation and Completion of the Synthesis of Analogue 130 ............... 44 


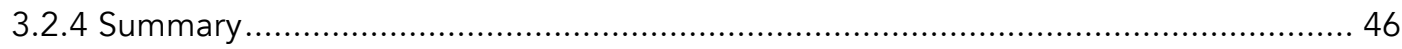

3.3 Towards the Synthesis of a Side Chain-containing Analogue of $130 \ldots \ldots .47$

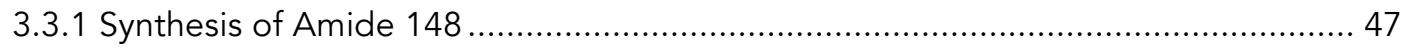

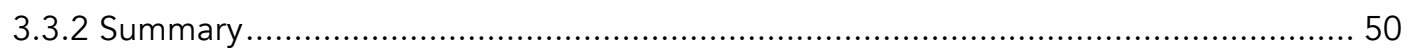

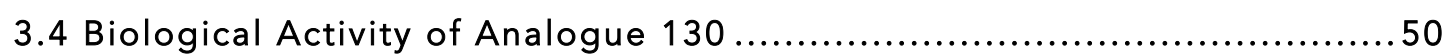

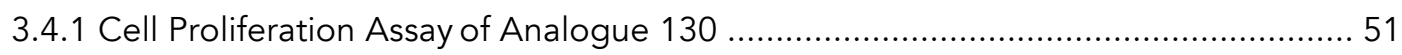

3.4.2 Competitive Bioactivity Assay Between Analogue 130 and Pateamine.................. 52

CHAPTER FOUR: CONCLUSION AND FUTURE WORK $\ldots \ldots \ldots \ldots \ldots \ldots \ldots \ldots \ldots \ldots . \ldots \ldots \ldots$

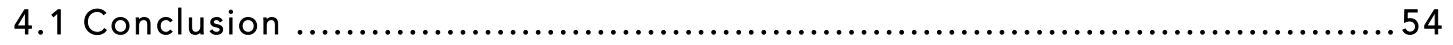

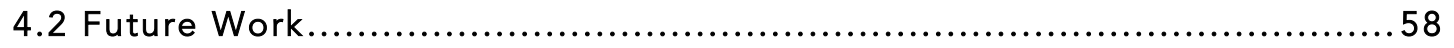

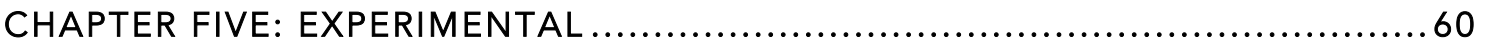

5.1 General Experimental for Chemical Synthesis ..............................60

5.2 Experimental for Chemical Synthesis .......................................61 61

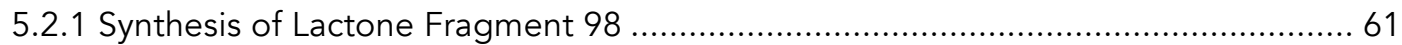

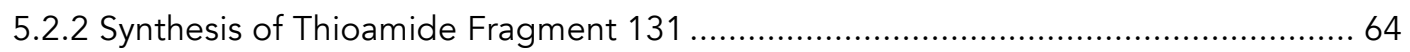

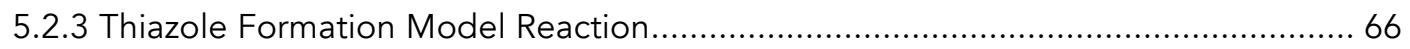

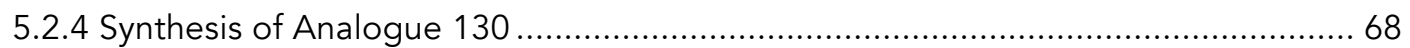

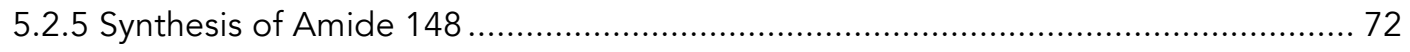

5.3 Experimental for Biological Testing ........................................74

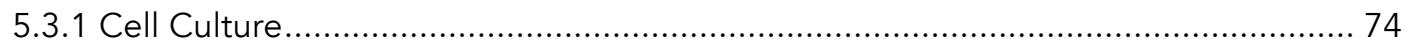

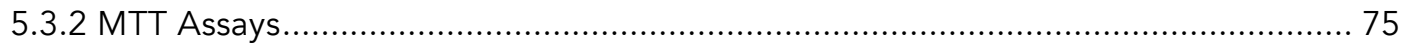

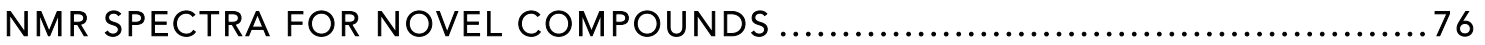

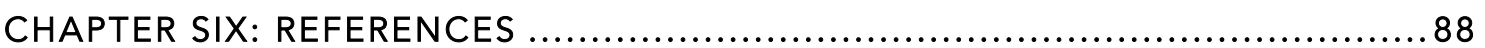




\section{ABBREVIATIONS}

Ac

Acetyl

ADP

Adenosine diphosphate

APP

Amyloid precursor protein

app.

Apparent

aq

Aqueous

arom.

Aromatic

ATP

Adenosine triphosphate

ATR

Attenuated total reflectance

$\mathrm{Bu}$

Butyl

cat.

Catalytic

DCM

Dichloromethane

DDQ

2,3-Dichloro-5,6-dicyano-1,4-benzoquinone

DIBAL

Diisobutylaluminium hydride

DIPEA Diisopropylethylamine

DMAP 4-Dimethylaminopyridine

DMDA Des-methyl des-amino

DMF Dimethylformamide

DMSO Dimethyl sulfoxide

EDCl N-(3-Dimethylaminopropyl)- $N$ '-ethylcarbodiimide

elF

Eukaryotic initiation factor

Et

Ethyl

FDA

Food and drug administration

HMDS

Hexamethyldisilazide

HPLC

High performance liquid chromatography

HRMS

High resonance mass spectrometry

IAV

Influenza A virus

$\mathrm{IC}_{50}$

Half maximal inhibitory concentration

IL

Interleukin

iNOS

Inducible NO synthase

IR

Infrared

MALDI Matrix-assisted laser desorption/ionisation

mCPBA meta-Chloroperoxybenzoic acid 


\begin{tabular}{|c|c|}
\hline $\mathrm{Me}$ & Methyl \\
\hline Mor-DalPhos & Di(1-adamantyl)-2-morpholinophenylphosphine \\
\hline mRNA & Messenger ribonucleic acid \\
\hline Ms & Mesyl/methanesulfonyl \\
\hline MTT & 3-(4,5-Dimethylthiazol-2-yl)-2,5-diphenyltetrazolium bromide \\
\hline $\mathrm{m} / \mathrm{z}$ & Mass to charge ratio \\
\hline NF & Nuclear factor \\
\hline NMR & Nuclear magnetic resonance \\
\hline NS-1 & Non-structural protein 1 \\
\hline PE & Petroleum ether \\
\hline $\mathrm{Ph}$ & Phenyl \\
\hline PMB & para-Methoxybenzyl ether \\
\hline pTSA & para-Toluenesulfonic acid \\
\hline $\mathrm{R}$ & Unspecified substituent \\
\hline RCF & Relative centrifugal force \\
\hline $\mathrm{R}_{f}$ & Retardation factor \\
\hline rt & Room temperature \\
\hline sat. & Saturated \\
\hline SM & Starting material \\
\hline TBAF & Tetrabutylammonium fluoride \\
\hline TBAl & Tetrabutylammonium iodide \\
\hline TBS & tert-Butyldimethylsilyl \\
\hline TBDPS & tert-Butyldiphenylsilyl \\
\hline TCBC & 2,4,6-Trichlorobenzoyl chloride \\
\hline Tf & Triflyl/ Trifluoromethylsulfonyl \\
\hline THF & Tetrahydrofuran \\
\hline TIPS & Triisopropylsilyl \\
\hline TLC & Thin layer chromatography \\
\hline TOF & Time of flight \\
\hline TPS & Triphenylsilyl \\
\hline UTR & Untranslated region \\
\hline UV & Ultraviolet \\
\hline VUW & Victoria University of Wellington \\
\hline
\end{tabular}




\section{CHAPTER ONE: INTRODUCTION}

\subsection{Research Introduction}

The purpose of this research is to design and synthesise a highly simplified analogue of the natural product pateamine, isolated from the marine sponge Mycale hentscheli. ${ }^{1}$ A previously developed simplified pateamine analogue has demonstrated comparable anticancer properties to those of pateamine; ${ }^{2}$ thus, the goal of this research is to synthesise a highly simplified pateamine analogue, devoid of pateamine's side chain, to evaluate synthetic methodology for future syntheses of simplified pateamine analogues. The synthesis of this side chain-free analogue will also allow for the investigation of its binding to the biological target of pateamine, elF4A.

\subsection{Natural Products and Analogues in Drug Discovery}

Natural products are chemical compounds produced by living organisms that are synthesised via primary or secondary metabolism. Organisms such as plants, bacteria, fungi and marine organisms evolve and adapt to their environment by producing compounds that aid in their survival against predators.

Secondary metabolites are not directly involved in growth, development or reproduction, but instead confer competitive advantages to the organism. ${ }^{3}$ These metabolites are often terpenoids, alkaloids, polyketides, glycosides or steroids. ${ }^{4}$ As secondary metabolites synthesised by the host often exert biological effects on other organisms, they represent valuable sources for leads in drug discovery, and therefore are of great importance to pharmaceutical companies and academic researchers. ${ }^{5}$ In the 30 years leading up to 2010, natural products, natural product mimics and their semi-synthetic derivatives comprised the majority (64\%) of all new drug candidates approved by the United States Food and Drug Administration (FDA) (Figure 1.1). ${ }^{5}$ 


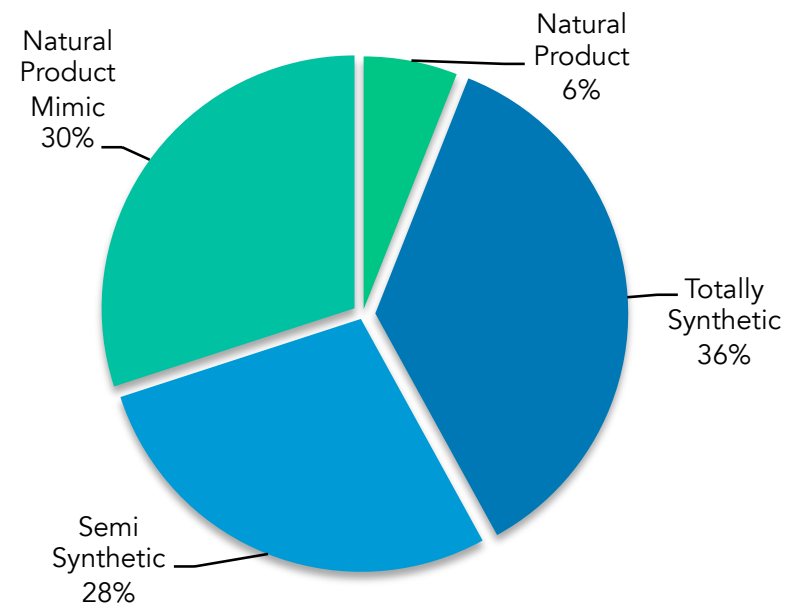

Figure 1.1 Sources of small-molecule FDA approved drugs between 1980 and 2010 (modified from Newman). ${ }^{5}$

Marine invertebrates and sessile organisms such as algae, corals, and sponges are in constant competition for a suitable environment. These organisms have evolved to produce secondary metabolites as a means of defence against predation and overgrowth of competing organisms, or to subdue fish and other prey for ingestion. ${ }^{4}$ In order to overcome the dilution effects of seawater, these secondary metabolites are usually extremely potent, resulting in drug leads that often possess very high biological activity in humans. ${ }^{6}$

As secondary metabolites are not essential for life, and are metabolically expensive to synthesise, they are often present in the marine organism in small quantities. To avoid depleting natural colonies of these organisms, it is advantageous to synthesise these compounds, and analogues of these compounds, in the laboratory.

An analogue is a compound that has a structural or functional relationship to the drug candidate. The synthesis of secondary metabolite analogues is often explored to improve the pharmacological activity of the compound or to simplify its chemical structure in order to facilitate large-scale synthesis. A majority of secondary metabolites contain stereogenic centres, which are often difficult to incorporate during synthesis as they may require expensive chiral starting materials, reagents or catalysts; incorporating fewer stereocentres into the analogue can expedite the synthesis, ideally without disrupting the biological activity of the secondary metabolite. ${ }^{2}$

An example of a successful simplified analogue with fewer stereocentres is picolog (Figure 1.2), an analogue of the natural product bryostatin 1, which was synthesised by Wender and 
colleagues with an overall yield of $2 \%$ in 19 steps for the longest linear sequence. ${ }^{7,8}$ This was substantially lower than that of bryostatin 1, which was synthesised in 30 steps for the longest linear sequence by Keck and co-workers. ${ }^{9}$

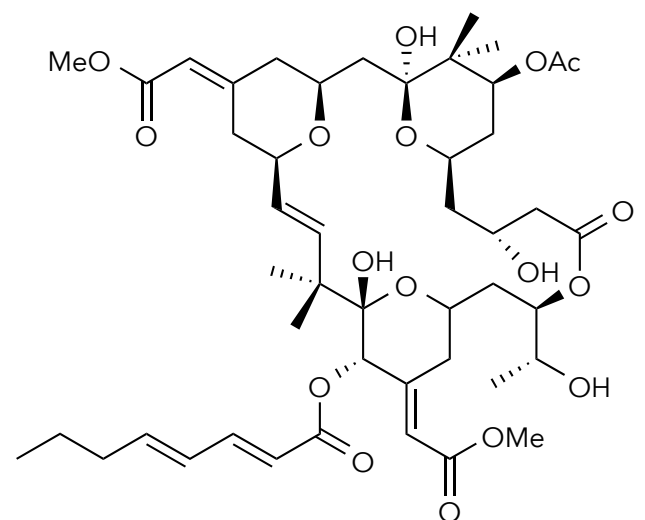

Bryostatin 1

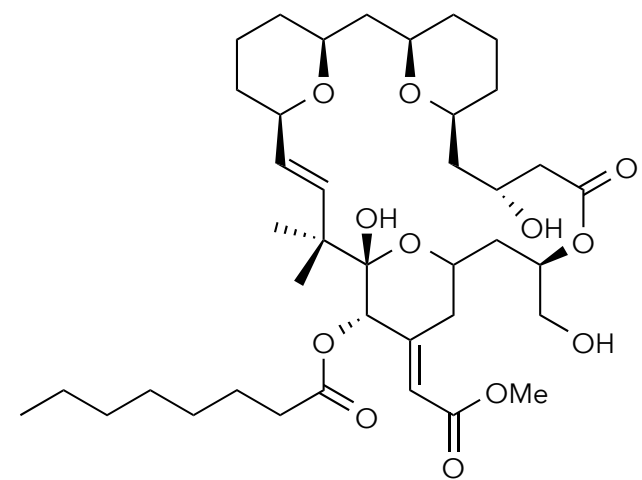

Picolog

Figure 1.2 Structures of bryostatin 1 and its analogue picolog. ${ }^{7}$

Despite the simplification of the structure, picolog exhibited greater growth inhibition of murine tumour-derived lymphoma cells compared to bryostatin 1, and is a potential anticancer lead. ${ }^{7}$

\subsection{Discovery of Pateamine}

Pateamine (Figure 1.3) is a secondary metabolite that was isolated by Northcote and colleagues from the marine sponge Mycale hentscheli found on the coast of the South Island of New Zealand in 1991. ${ }^{1}$ Three congeners of pateamine were isolated: pateamine A, B and C, which differ from each other at the terminal group of the trienylamine side chain; however, "pateamine" will be used in the remainder of this thesis to represent pateamine $A$, as it is the major congener with reported biological activity. 


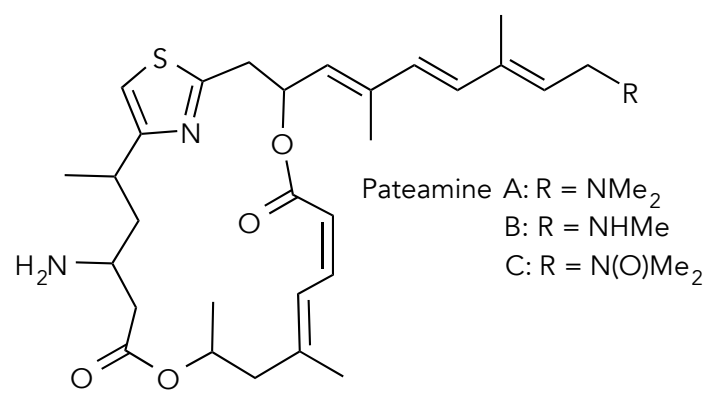

Figure 1.3 Two-dimensional structures of pateamine A, B and C. ${ }^{1}$

The absolute configuration of pateamine (1, Figure 1.4) was later unequivocally assigned as $(3 R, 5 S, 10 S, 24 S)$ by Romo and colleagues in $1995 .{ }^{10,11}$

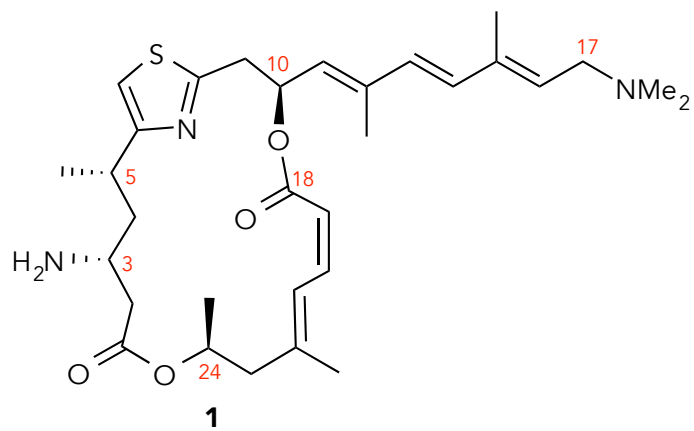

Figure 1.4 Absolute configuration of pateamine. ${ }^{11}$

Initial biological studies undertaken by Northcote and colleagues showed that pateamine is extremely cytotoxic with high selectivity towards cancer cell lines (see Section 1.5.1), which resulted in international interest from the medicinal chemistry community. ${ }^{12}$ As the amount of pateamine required for pre-clinical and clinical testing cannot be easily isolated from Mycale hentscheli, synthesis of pateamine and its analogues is necessary to further examine its potential as an anticancer lead. ${ }^{11}$

\subsection{Pateamine and Analogue Synthesis}

Two research groups have successfully synthesised pateamine; Romo and colleagues in $1998,{ }^{11}$ and Pattenden and co-workers in 2000. ${ }^{13}$ Romo and colleagues later developed a simplified pateamine analogue in 2004, ${ }^{14}$ and second-generation analogues of pateamine in 2014. ${ }^{2}$ In 2013, Hemi Cumming, a former PhD student at Victoria University of Wellington (VUW), synthesised a simplified triazole-containing pateamine analogue. ${ }^{15}$ These syntheses are described in detail below. 


\subsubsection{Total Synthesis of Pateamine by Romo}

Romo's strategy for the total synthesis of pateamine involved the formation of three major fragments: $\beta$-lactam 2 , enyne acid 3 and dienyl amino stannane 4 (Figure 1.5). ${ }^{11}$

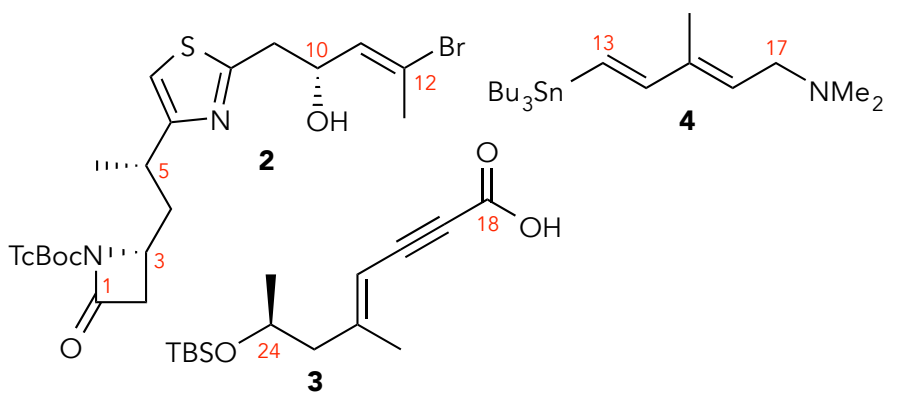

Figure 1.5 Major fragments for the synthesis of pateamine. ${ }^{11}$

$\mathrm{TcBoc}=2,2,2$-trichloro-tert-butyloxycarbonyl.

Fragments 2 and 3 were coupled together through Mitsunobu esterification, followed by $\beta$ lactam-opening macrolactonisation to provide the 19-membered bis-lactone core. Fragment 4 was then attached to the bis-lactone core via Stille cross coupling to provide pateamine.

\section{Synthesis of $\beta$-Lactam 2}

The $\beta$-lactam 2 contains three stereocentres: at carbons 3,5 and 10. Control of the stereochemical configurations at carbons 3 and 10 was achieved through the use of $\mathrm{N}$-acetyl thiazolidinethione 5 (Schemes 1.1 and 1.2). At carbon 3 the configuration produced was inverted relative to pateamine, which fitted the planned Mitsunobu esterification strategy.

A Nagao acetate aldol reaction between 5 and aldehyde 6, followed by silyl protection and cleavage of the auxiliary with ammonia gave amide 9 (Scheme 1.1). Conversion of 9 to thioamide 10 was attempted with Lawesson's reagent; however, this led to the formation of a nitrile due to undesired dehydration of the amide. ${ }^{11}$ Successful conversion to thioamide 10 was achieved using Belleau's reagent, and this was followed by thiazole formation using modified Hantzsch conditions. ${ }^{11}$ Partial reduction of the ester group 11 to the corresponding aldehyde was followed by Horner-Wadsworth-Emmons olefination with the oxazolidinone-containing phosphonate 13 to afford compound 14. The configuration of carbon 5 was obtained through 
auxiliary-controlled conjugate addition, achieved by the treatment of 14 with a Grignard reagent in the presence of copper(l) to give the methylated product 15. Transamidation of 15 to the Weinreb amide followed by partial reduction afforded the aldehyde $17 .{ }^{11}$
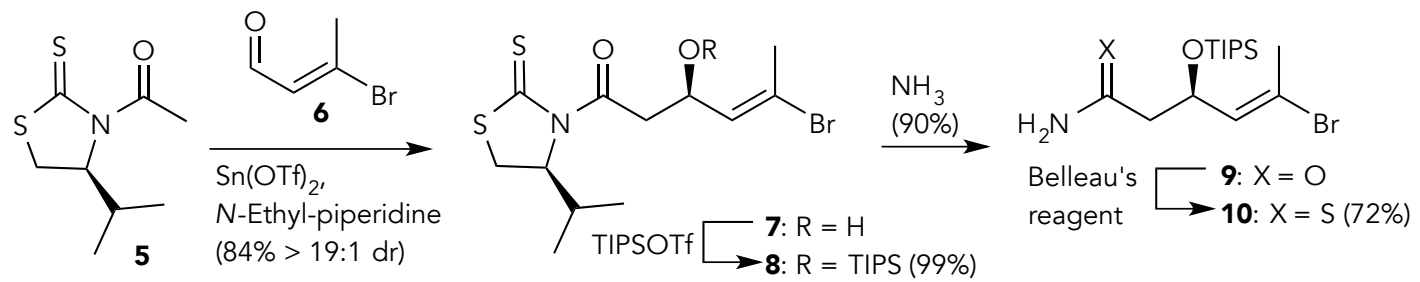

$(84 \%>19: 1 \mathrm{dr})$
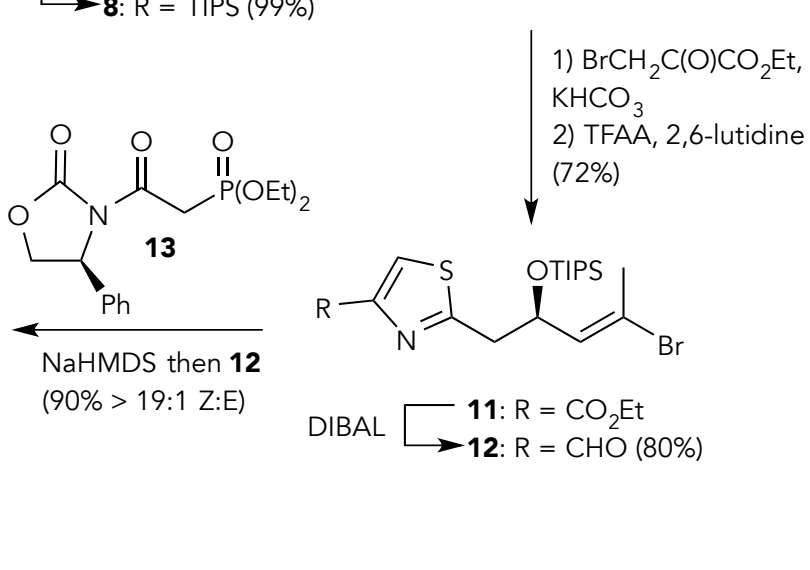<smiles>C/C(Br)=C\[C@@H]([OH+])Cc1nc(/C=C/C(=O)N2C(=O)OC[C@H]2c2ccccc2)cs1</smiles>
CuBr.DMS $\mathrm{MeMgBr}$ (77\% 6.4:1 dr)<smiles>[R]C(=O)C[C@@H](C)c1csc(C[C@H](/C=C(\C)Br)O[SnH3])n1</smiles>

Scheme 1.1 Introduction of stereochemistry at carbon 5 and 10 in preparation for $2 .{ }^{11}$ TFAA $=$ trifluoroacetic anhydride, $\mathrm{DMS}=$ dimethyl sulfide.

A second aldol reaction of 5 with aldehyde 17 provided 18 (Scheme 1.2). Transamidation of 18 to benzyloxyamide 19, followed by an intramolecular Mitsunobu reaction, provided the $\beta$ lactam 20 with inversion at carbon 3 to give the correct $(R)$-configuration. Several protection and deprotection steps led to the synthesis of the desired $\beta$-lactam 2 in an overall $5 \%$ yield. ${ }^{11}$ 


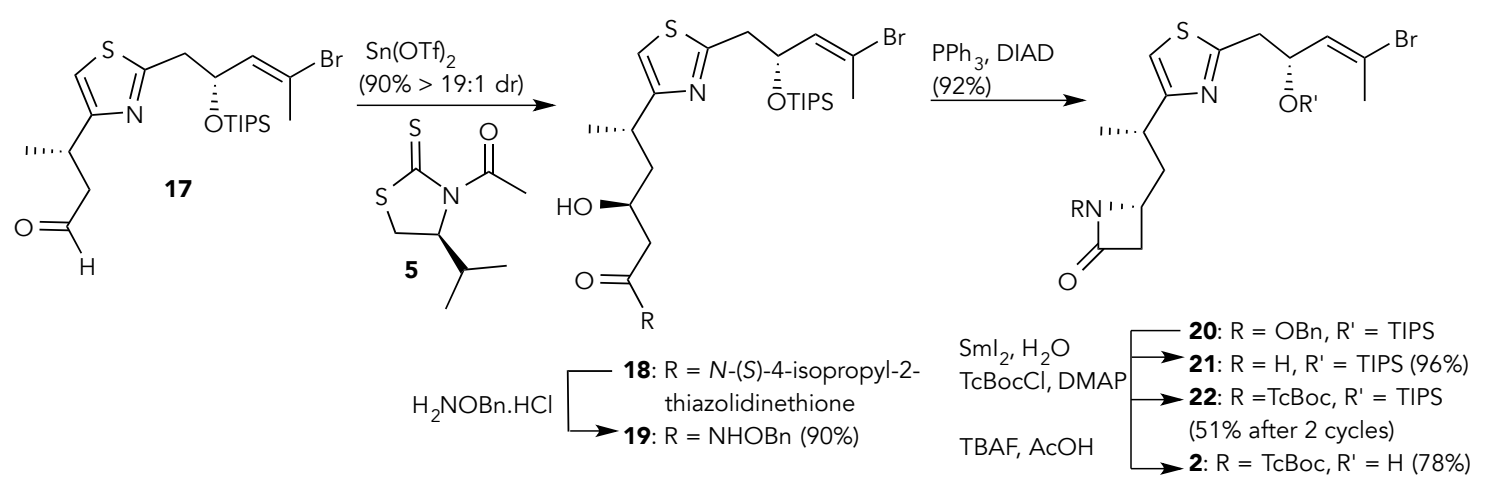

Scheme 1.2 Introduction of configuration at carbon 3 and completion of $2 .{ }^{11}$

$\mathrm{DIAD}=$ diisopropyl azodicarboxylate, $\mathrm{TcBoc}=2,2,2$-trichloro-tert-butyloxycarbonyl, $\mathrm{Bn}=$ benzyl.

\section{Synthesis of Enyne Acid 3}

Control of the configuration of carbon 24 was achieved through Noyori hydrogenation of ethyl acetoacetate 23 (Scheme 1.3). The ester 25 was partially reduced and converted to acetylene 26 using the Corey-Fuchs procedure. ${ }^{11}$ Carboalumination and iodination of 26 led to the vinyl iodide 27 , which was then transformed by Sonogashira coupling with propargyl alcohol 28 to the enyne alcohol 29. A two-step oxidation afforded the enyne acid 3 in an overall $22 \%$ yield. ${ }^{11}$

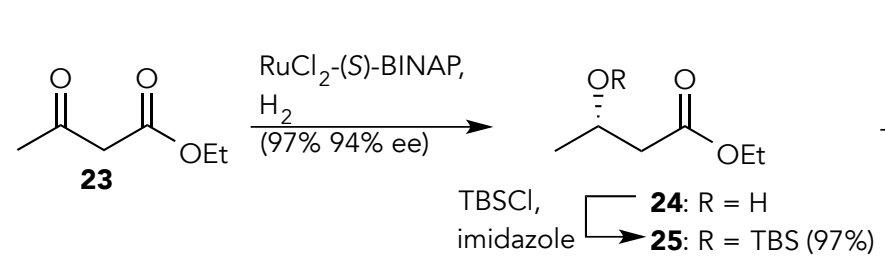<smiles>CC(=CC#CC(=O)O)CC(C)O</smiles>

3

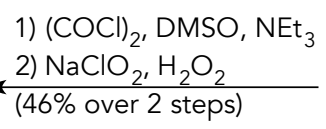
2) $\mathrm{NaClO}_{2}, \mathrm{H}_{2} \mathrm{O}_{2}$

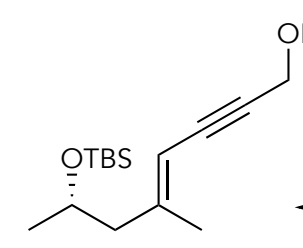

29
1) DIBAL

2) $\mathrm{Zn}^{0}, \mathrm{PPh}_{3}, \mathrm{CBr}_{4}$ $\underset{\text { (8) BuLi over } 3 \text { steps) }}{\longrightarrow}$<smiles>C#CC[C@H](C)O[Mg]</smiles>

26

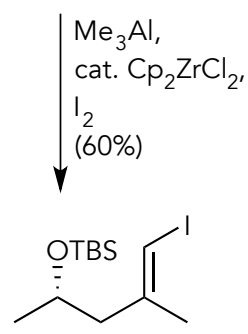

27

Scheme 1.3 Synthesis of enyne acid $3 .^{11}$

$\mathrm{BINAP}=$ 2,2-bis(diphenylphosphino)-1,1-binaphthalene. $\mathrm{Cp}=$ cyclopentadienyl. 
The synthesis of dienyl amino stannane 4 was accomplished in four steps from the known enyne alcohol 30 in an overall yield of $49 \%$ (Scheme 1.4), via a one-pot tosylation and displacement with diethylamine, followed by stannylcupration. ${ }^{11}$

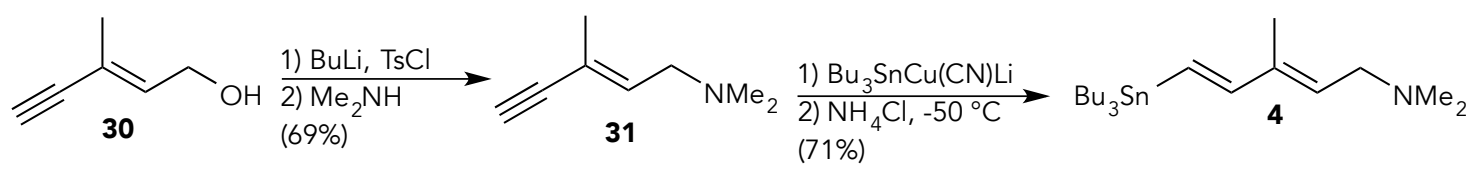

Scheme 1.4 Synthesis of dienyl amino stannane $4 .{ }^{11}$

$$
\text { Ts }=\text { tosyl. }
$$

Coupling of Fragments 2, 3 and 4 for the Completion of the Synthesis of Pateamine (1)

The $\beta$-lactam 2 and enyne acid 3 were coupled together via a Mitsunobu esterification (Scheme 1.5), which inverted the configuration at carbon 10 to give the correct (S)configuration. Macrolactonisation was achieved through a $\beta$-lactam opening to provide the bislactone core 34, and the alkyne was then reduced using a Lindlar catalyst to give the $Z, E$ dienoate 35 . The dienyl amino stannane side chain 4 was attached to the macrocycle core via a Stille coupling to provide 36 . This reaction was stopped before completion and, based on recovered starting material 35 that was recycled, provided a yield of $57 \%$, whereas a yield of $27 \%$ was obtained when the reaction was left until completion. Finally, deprotection provided pateamine (1) with an overall yield of $0.2 \%$ in 24 steps based on the longest linear sequence. ${ }^{11}$ 

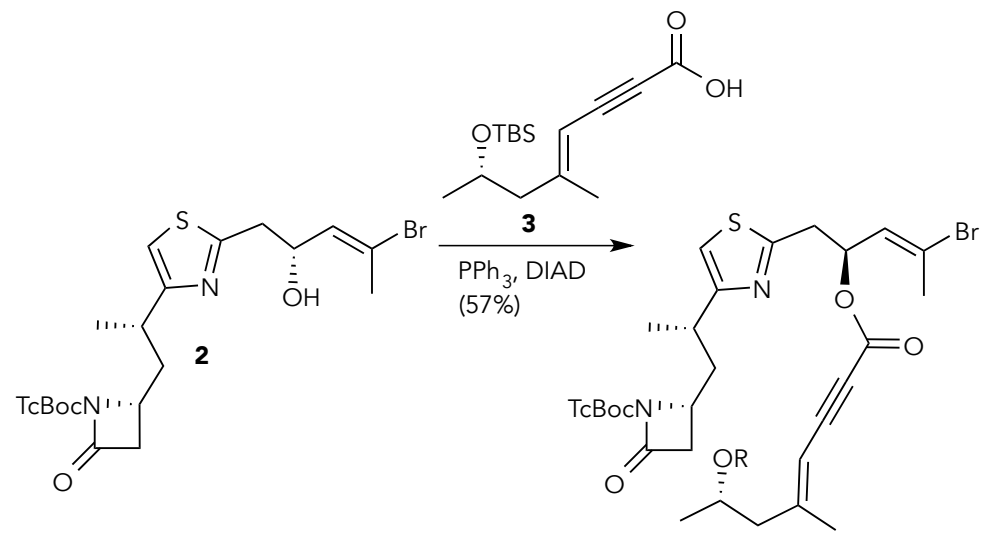

$$
\begin{aligned}
\text { HF.pyridine } \longrightarrow \text { 32: } \mathrm{R}=\mathrm{TBS} \\
\longrightarrow \text { 33: } \mathrm{R}=\mathrm{H}(78 \%)
\end{aligned}
$$

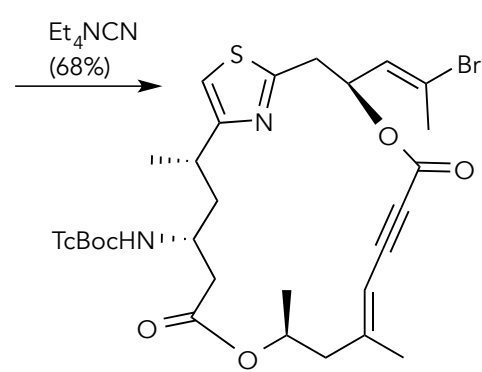

34

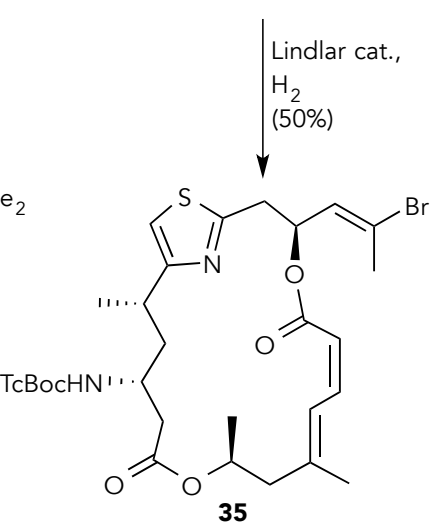

10\% Cd-Pb $\longrightarrow$ 36: $\mathrm{R}=\mathrm{TcBoc}$
$\longrightarrow$ 1: $\mathrm{R}=\mathrm{H}$ (Pateamine) $(78 \%)$

Scheme 1.5 Coupling of fragments 2, 3 and 4 to complete the synthesis of pateamine $1 .{ }^{11}$ $\mathrm{DIAD}=$ diisopropyl azodicarboxylate, $\mathrm{dba}=$ dibenzylideneacetone, $\mathrm{TcBoc}=2,2,2$-trichloro-tertbutyloxycarbonyl.

\subsubsection{Total Synthesis of Pateamine by Pattenden}

Pattenden's approach for the synthesis of pateamine differs from that of Romo, in that Pattenden uses a more convergent synthesis, with five major fragments to Romo's three, and has all stereochemical control arise from the use of chiral starting materials, ${ }^{13}$ whereas Romo opted for a mix of chiral starting materials and the use of chiral auxiliaries. ${ }^{11}$

The five major fragments for Pattenden's total synthesis of pateamine were sulfinimine 37, iodide 38, stannylpropenoic acid 39, amino stannane 40, and commercially available 2(triphenylphosphoranylidene) propionaldehyde (41) (Figure 1.6). ${ }^{13}$ The fragments 37,38 , and 39 formed the 19-membered bis-lactone core; to which fragments 40 and 41 were attached to form the trienylamine side chain. ${ }^{13}$ 


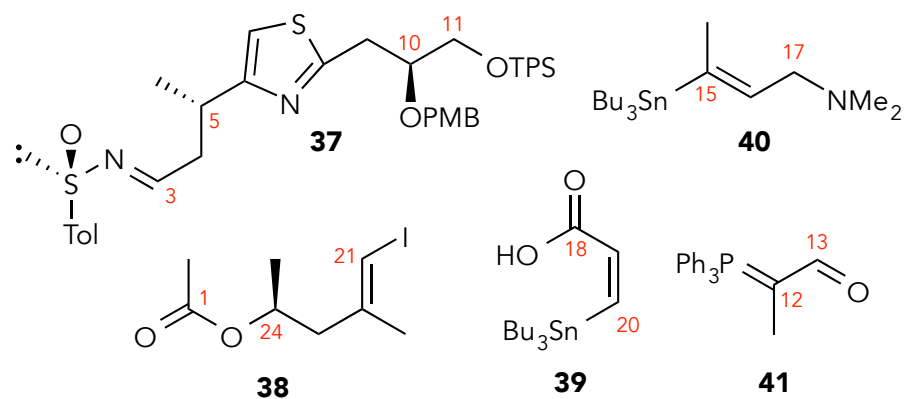

Figure 1.6 Major fragments in the Pattenden synthesis. ${ }^{13}$

The chiral acetate 38 was synthesised from (S)-4-pentyn-2-ol ${ }^{16}$ via a zirconium-catalysed carboalumination and iodination, following conditions described by Rand and colleagues. ${ }^{13,17}$ Stannylpropenoic acid 39 was synthesised by the saponification of ethyl Z-3-(tributylstannyl) acrylate (prepared from ethyl propiolate) ${ }^{18}$ with lithium hydroxide. ${ }^{13}$

\section{Synthesis of Sulfinimine 37}

The synthesis of sulfinimine 37 involved the coupling of two fragments, 46 and 53 , through the Hantzsch thiazole reaction.

The commercially available methyl (S)-3-hydroxy-2-methylpropionate (42) provided the configuration at carbon 5, and fragment 46 (Scheme 1.6) was synthesised in an overall yield of $47 \%$, via the Weinreb amide 44 , methylation to afford methyl ketone 45 , and $\alpha$-bromination. ${ }^{16}$

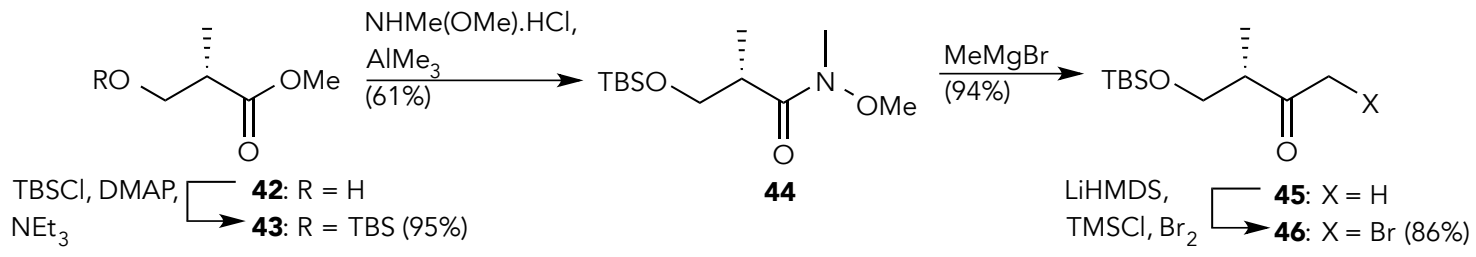

Scheme 1.6 Introduction of stereochemistry at carbon 5 in preparation for $37 .^{13}$

Fragment 53 (Scheme 1.7) was synthesised from commercially available L-malate (47), which provided the stereochemistry at carbon 10. Monoreduction of the diester produced diol 48, and after sequential protection of the primary and secondary hydroxyl groups, saponification gave acid 51 . The acid 51 was converted to amide 52 , followed by treatment with Lawesson's reagent to give 53 in an overall yield of $58 \% .^{13}$ 

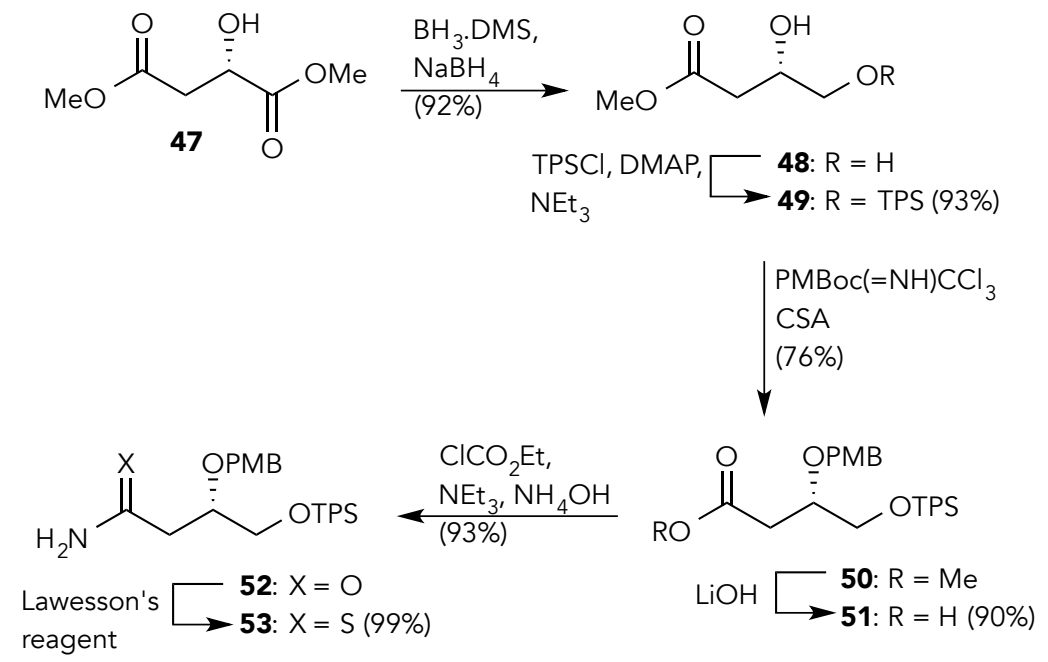

Scheme 1.7 Introduction of stereochemistry at carbon 10 in preparation for $37 .^{13}$ DMS = dimethyl sulfide, $\mathrm{CSA}=$ camphorsulfonic acid.

With $\alpha$-bromoketone 46 and thioamide 53 in hand, a modified Hantzsch thiazole synthesis was used to afford the thiazole 54 (Scheme 1.8). Mesylation and substitution with cyanide was followed by reduction to afford aldehyde 56, and subsequent treatment with $(R)$ tolylsulfinamide provided 37 in an overall yield of $12 \% .^{13}$

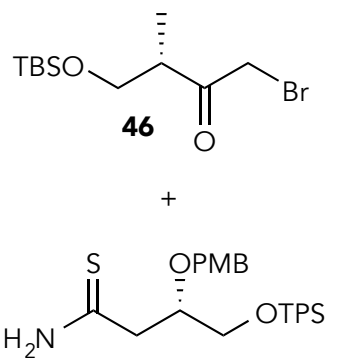

53
1) 2,6-lutidine

2) TFAA, pyridine

(64\% over 2 steps)<smiles>C1CCCCC1</smiles>

$\mathrm{RO}$ $\mathrm{AcOH}, \mathrm{THF}$ $\mathrm{H}_{2} \mathrm{O}$<smiles>[R9]CCc1csc(C[C@@H](C[OH+])O[Na])n1</smiles>

$\begin{aligned} \text { 54: } R & =T B S \\ \text { 55: } R & =H(92 \%)\end{aligned}$ 1) $\mathrm{MsCl}, \mathrm{NEt}_{3}$ 2) $\mathrm{NaCN}, \mathrm{DMSO}$ 3) DIBAL (65\% over 3 steps)

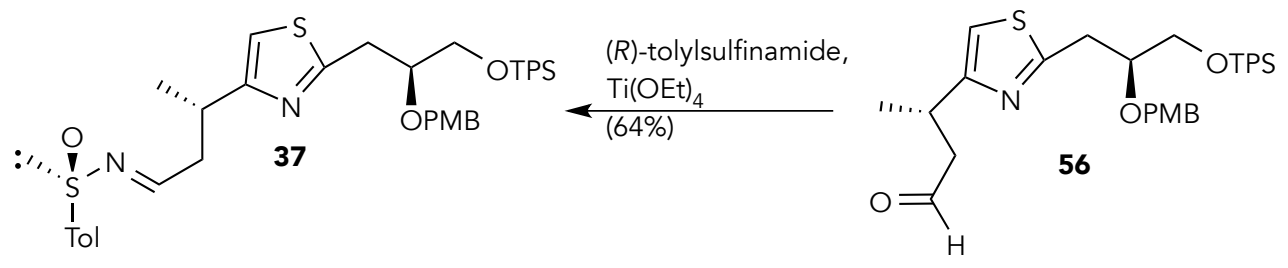

Scheme 1.8 Completion of the synthesis of $37 . .^{13}$

TFAA = trifluoroacetic anhydride, $\mathrm{Tol}=$ tolyl. 
Treatment of iodide 38 with lithium hexamethyldisilazide (LiHMDS) provided an enolate, which was coupled to sulfinimine 37 via an asymmetric aldol-like reaction to provide 57 . After protecting group alterations, stannylpropenoic acid 39 was coupled to alcohol 60 using Yamaguchi conditions to provide diester 61. Macrocyclisation was then achieved via Stille coupling to provide the bis-lactone core 62 , with complete preservation of the desired Z,Edienoate configuration in an overall yield of $3 \% .^{13}$

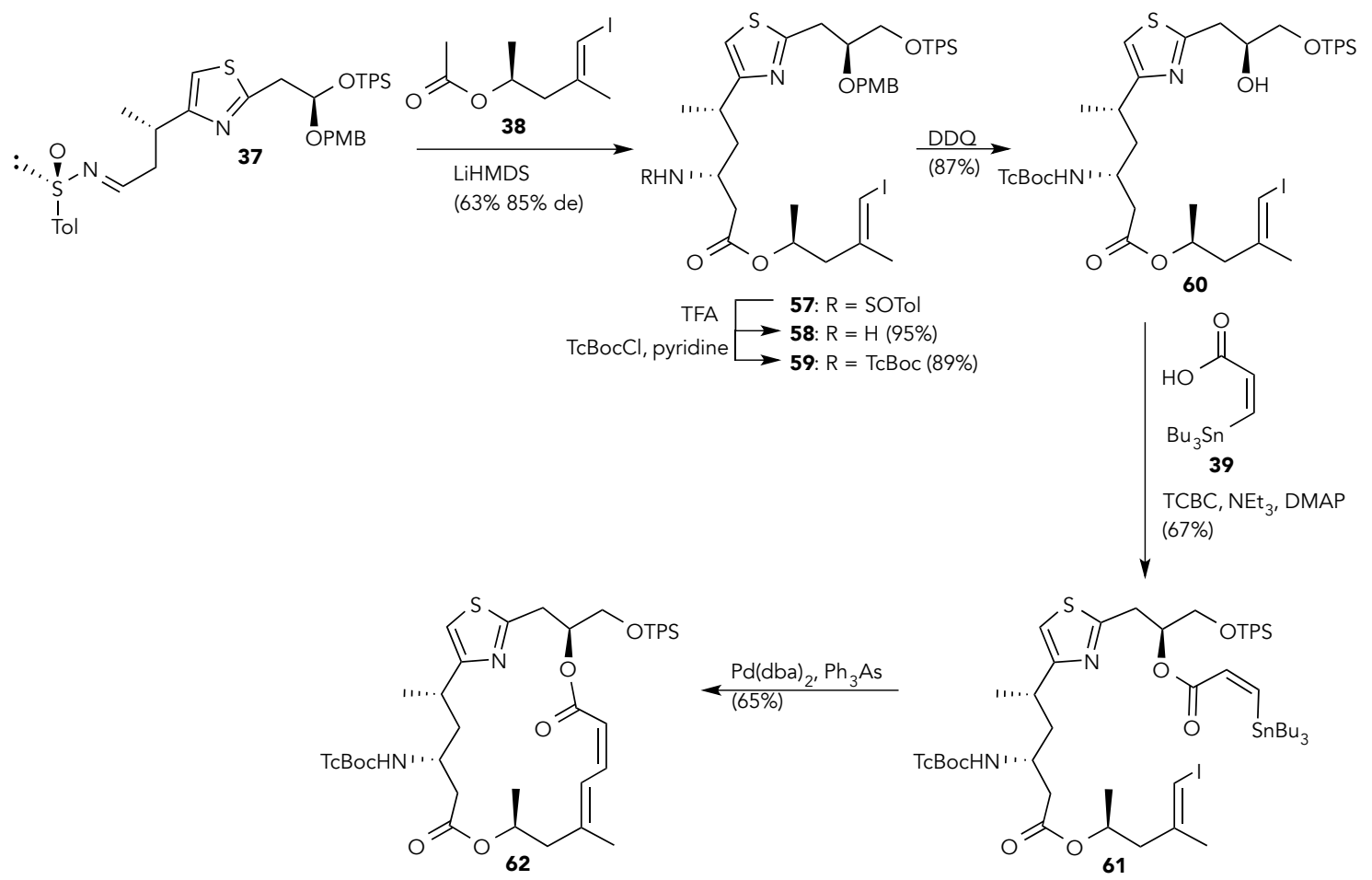

Scheme 1.9 Coupling of fragments 38,39 , and 60 to form bis-lactone core $62 .^{13}$ TFA = trifluoroacetic acid, $\mathrm{dba}=$ dibenzylideneacetone, $\mathrm{Tol}=$ tolyl, $\mathrm{TcBoc}=2,2,2$-trichloro-tertbutyloxycarbonyl.

Coupling of Fragments 40, 41 and 62 for the Completion of the Synthesis of Pateamine (1)

Desilylation and oxidation of bis-lactone core 62 was followed by Wittig olefination with 41 to produce the E-configured $\alpha, \beta$-unsaturated aldehyde 65 (Scheme 1.10), which was then converted to E-iodotriene 66 using the Takai procedure. ${ }^{19}$ Lastly, stannane 40 was attached to 
the macrocycle 66 through Stille coupling, which was followed by deprotection to afford pateamine (1) in an overall yield of $0.2 \%$ over 23 steps via the longest linear sequence. ${ }^{13}$

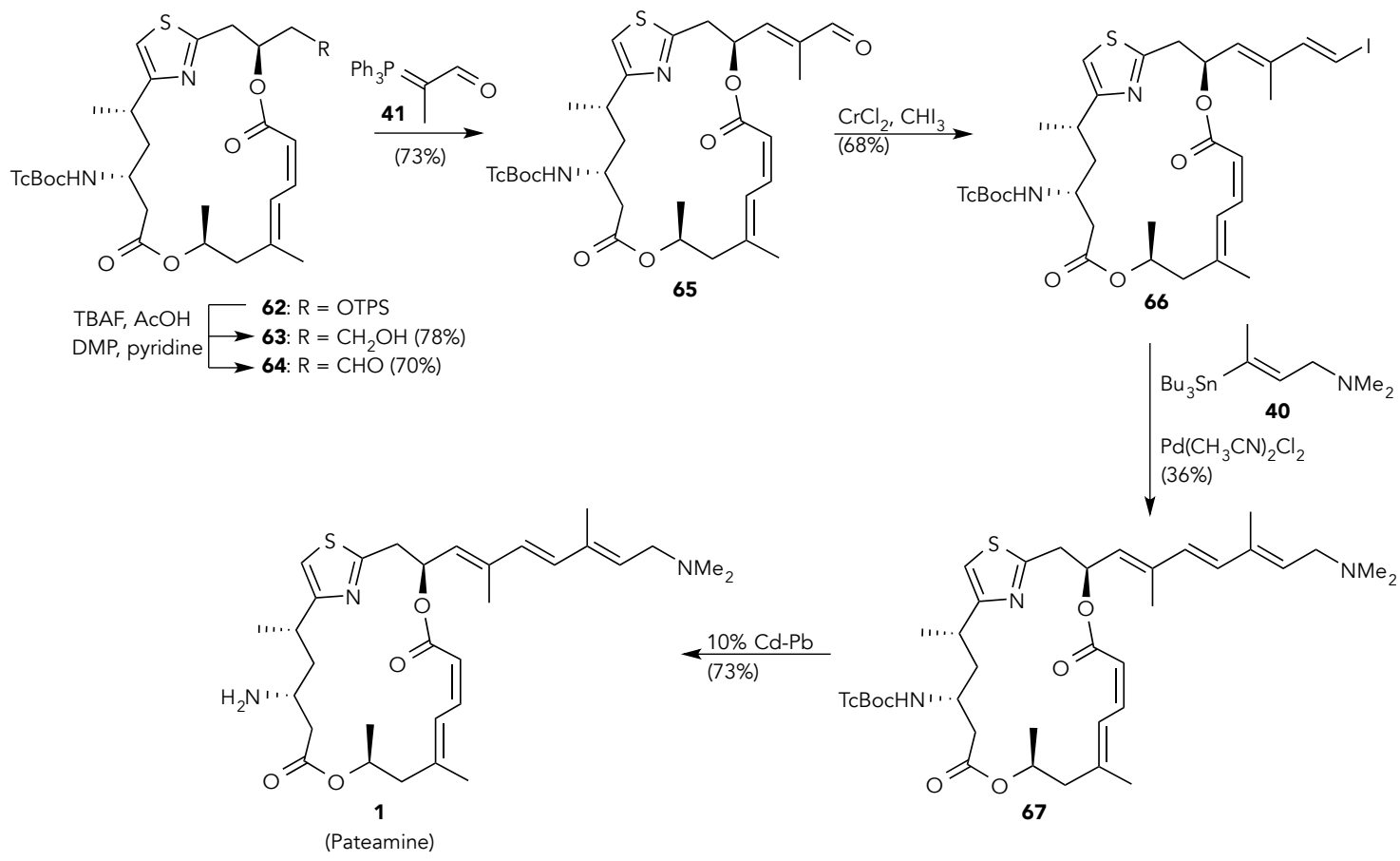

Scheme 1.10 Coupling of side chain fragments 40 and 41 to 62 for the completion of pateamine..$^{13}$ $\mathrm{TcBoc}=2,2,2$-trichloro-tert-butyloxycarbonyl, DMP = Dess-Martin periodinane.

Despite the substantially different approaches to the synthesis of pateamine by Romo and Pattenden, both syntheses have remarkably similar outcomes with overall yields of $0.2 \%$ in greater than 20 steps for the longest linear sequences. ${ }^{11,13}$ This provides an incentive for developing simplified pateamine analogues that contain fewer stereogenic centres, and can be synthesised in less synthetic steps.

\subsubsection{First Generation Analogues Prepared by Romo}

Romo and colleagues suggested that pateamine consists of separate binding and scaffolding domains, corresponding to conformationally rigid and flexible regions respectively (Figure 1.7). This hypothesis led to the synthesis of a range of first-generation analogues. ${ }^{14}$ 


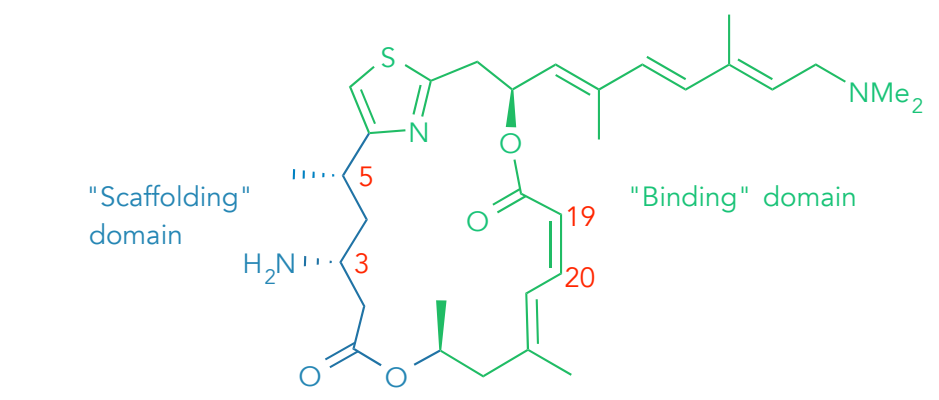

Figure 1.7 Hypothesised scaffolding (blue) and binding (green) domains of pateamine. ${ }^{14}$

The most potent analogue that Romo and colleagues synthesised was the des-methyl, desamino (DMDA) pateamine analogue 68 (Figure 1.8). The absence of the amino and methyl groups at carbons 3 and 5 removed two stereocentres from pateamine, thus greatly simplifying the synthesis (14 steps versus 24 steps for the longest linear sequence, as reported by Romo). ${ }^{14}$

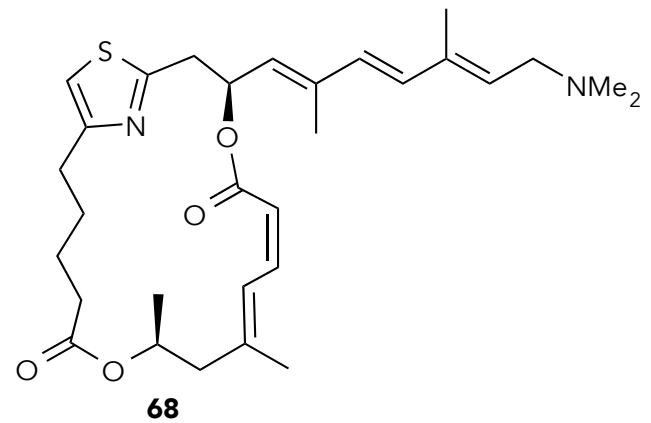

Figure 1.8 Structure of DMDA pateamine. ${ }^{14}$

The four major fragments for the synthesis of the DMDA analogue were thioamide 10, bromoketone 69, enyne acid 70 and dienyl stannane 4 (Figure 1.9). The syntheses of fragments 4 and 10 have been described previously (Schemes 1.1 and 1.4). A similar route to that of enyne acid 3 was followed for 70; however, the tert-butyldimethylsilyl (TBS) protecting group of 3 (Scheme 1.3) was replaced with the more robust protecting group triisopropylsilyl (TIPS) to afford $70 .{ }^{14}$ 


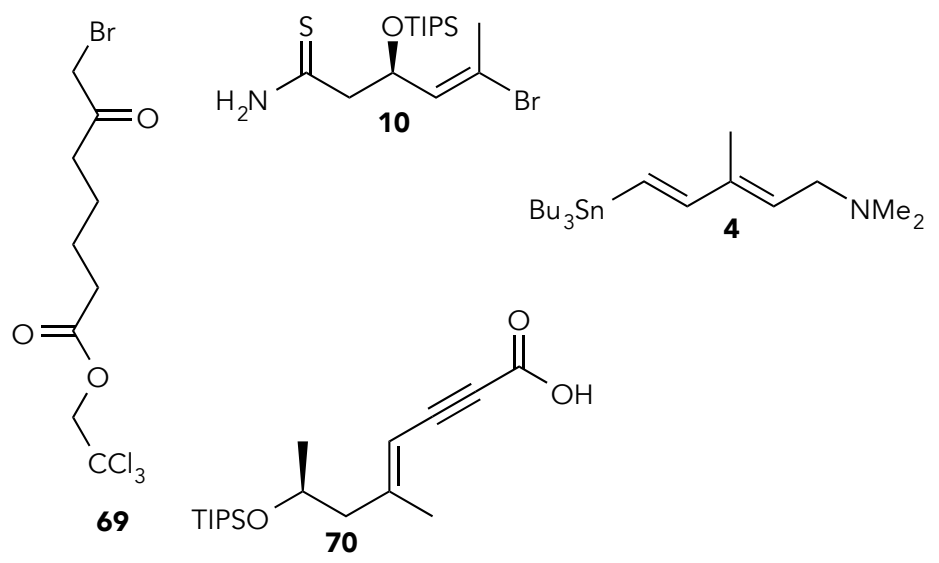

Figure 1.9 Four major fragments for the synthesis of DMDA pateamine. ${ }^{14}$

The bromoketone 69 was synthesised by the esterification and $\alpha$-bromination of 6 -oxoheptanoic acid (71) in an overall yield of $48 \%$ (Scheme 1.11). ${ }^{14}$

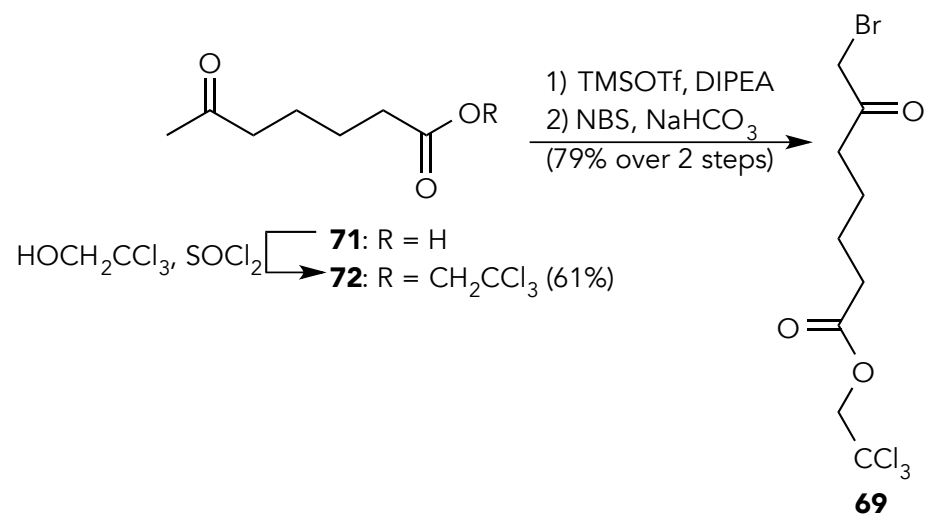

Scheme 1.11 Synthesis of $69 .{ }^{14}$

NBS $=N$-bromosuccinimide, TMS $=$ trimethylsilyl.

Coupling of Fragments 4, 10, 69 and 70 for the Completion of DMDA Analogue 68

The synthesis of DMDA pateamine started with the formation of thiazole 73 via a Hantzsch coupling reaction between bromoketone 69 and thioamide 10 (Scheme 1.12). ${ }^{14}$ Deprotection of 73 allowed for Mitsunobu coupling between alcohol 74 and enyne acid 70 to afford 75 with the correct (S)-configuration at carbon 10. Two deprotection steps were followed by Yamaguchi macrolactonisation to give the bis-lactone core 78. Reduction with Lindlar catalyst gave the desired Z,E-configured dienoate, which was subjected to a Stille coupling with dienyl amino stannane 4 to give the DMDA analogue 68 in an overall 7\% yield based on the longest 
linear sequence. ${ }^{14}$ The overall yield of the simplified pateamine analogue 68 was greatly improved over the $0.2 \%$ overall yield of pateamine.
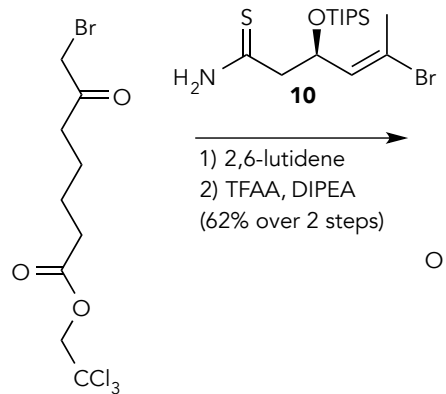

69
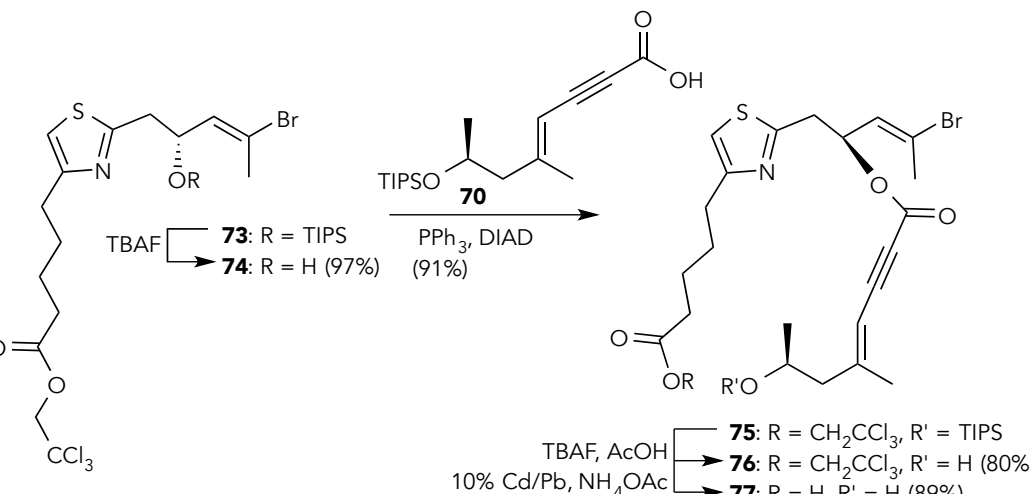

$10 \% \mathrm{Cd} / \mathrm{Pb}, \mathrm{NH}_{4} \mathrm{OAc} \longrightarrow$ 77: $\mathrm{R}=\mathrm{H}, \mathrm{R}^{\prime}=\mathrm{H}(89 \%)$

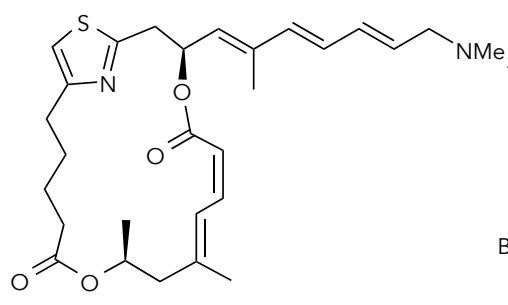

68

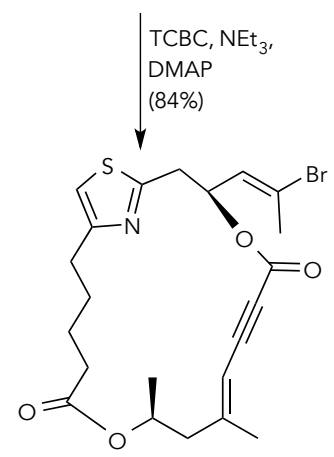

78

Scheme 1.12 Coupling of fragments 4, 10,69 and 70 and the completion of the DMDA analogue. ${ }^{14}$ TFAA = trifluoroacetic anhydride, DIAD = diisopropyl azodicarboxylate, dba = dibenzylideneacetone.

\section{Biological Activity of DMDA Pateamine}

Initial biological testing showed that the DMDA analogue had slightly higher potency in its ability to inhibit expression of the interleukin-2 (IL-2) reporter gene in stimulated Jurkat T cells $(0.8 \mathrm{nM})$ relative to pateamine $(4.0 \mathrm{nM}) .^{14}$ Further biological testing in 2014 showed that the DMDA analogue had similar potency in its ability to inhibit cell proliferation in a range of cancer cell lines compared to pateamine (see Section 1.5.1). ${ }^{2}$ These results help prove the hypothesis that pateamine contains a scaffolding domain that can be modified without affecting its biological activity. 


\subsubsection{Second Generation Analogues Prepared by Romo}

In 2014 Romo and colleagues reported the synthesis of second-generation analogues of pateamine. ${ }^{2}$ These analogues all incorporated the core of DMDA pateamine as a starting point with modifications at the side chain and changes to the dienoate system.

The analogues were categorised into three series (I, II and III) based on the structural characteristics of the macrocycle (Figure 1.10). Series I analogues retained the same Z,Edienoate moiety as pateamine and the DMDA analogue, series II analogues contained an enyne moiety, and series III analogues possessed an E,E-dienoate. These analogues were synthesised to test the structural flexibility in components of the previously identified binding domain (Figure 1.7), primarily the side chain and the olefin geometry at the carbon 19-20 positions.
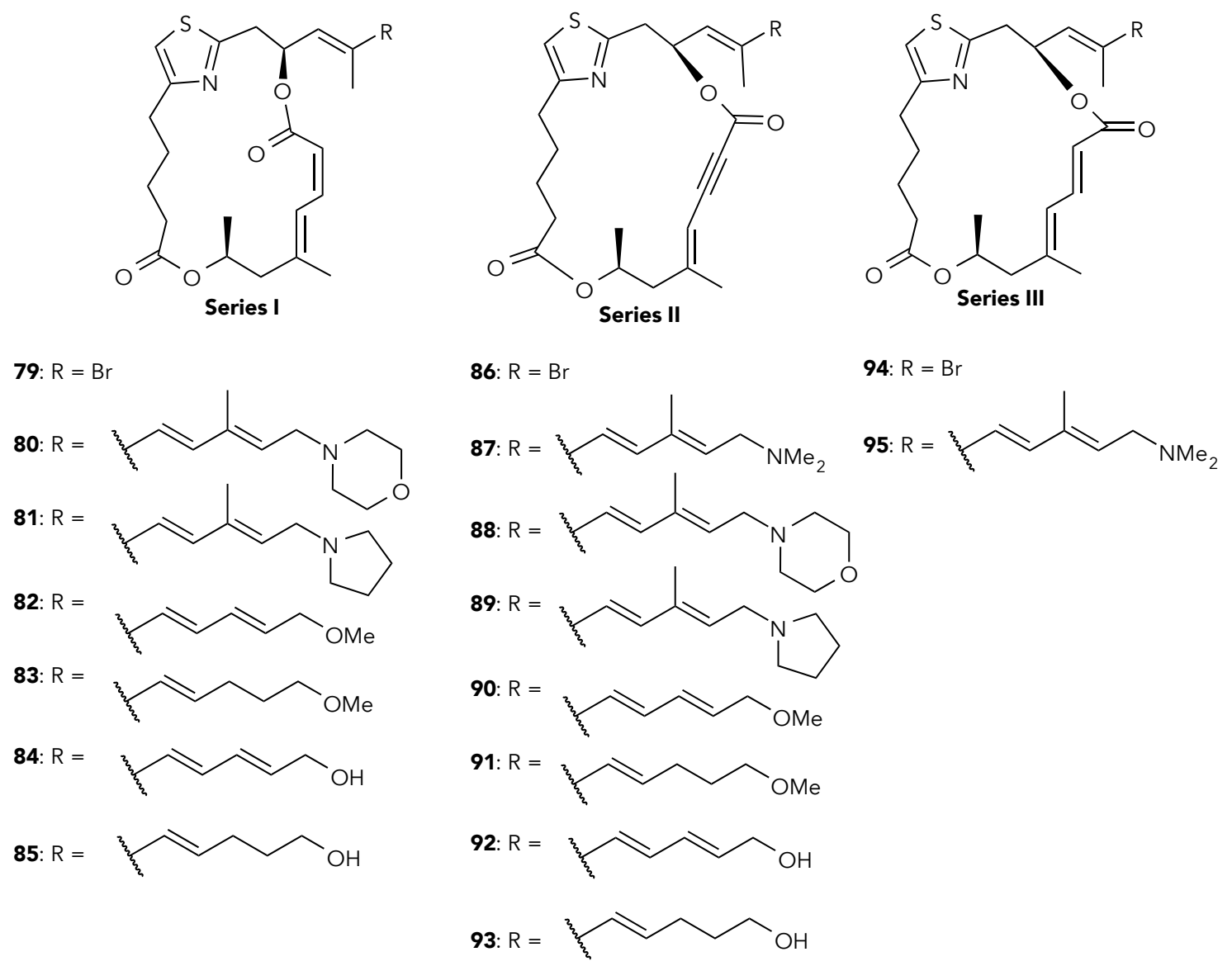

Figure 1.10 Second-generation analogues. ${ }^{2}$ 
All analogues were tested for cell proliferation inhibition activity using three cell lines: HeLa (human cervical cancer), SK-MEL2 (human malignant melanoma) and Jurkat $\mathrm{T}$ (human lymphocyte) cells.

The series II and III analogues showed little-to-no activity in the cell proliferation inhibition assays, which confirmed that the Z,E-dienoate of the macrocycle is essential for biological activity. ${ }^{2,14}$

The series I analogue 79, which is devoid of the side chain, showed at least a 700-fold loss of activity in SK-MEL2 and Jurkat T cells, and no observed biological activity in HeLa cells. ${ }^{2}$ These results indicate that the side chain is essential for biological activity of the analogue.

Analogues 80 and 81 were synthesised to investigate structural variations of the tertiary amine on the side chain in an attempt to increase the metabolic stability of DMDA pateamine by preventing the $\mathrm{N}$-demethylation metabolic process from occurring. ${ }^{2}$ The dimethylamine was replaced with a morpholine ring in 80 and a pyrrolidine ring in 81 . Analogue 80 showed a 400-fold loss of activity in HeLa cells, a 700-fold loss of activity in Jurkat T cells, and a 25-fold loss of activity in SK-MEL2 cells; however, analogue 81 only showed a 2-fold decrease of activity in all cell lines. ${ }^{2} \mathrm{~A}$ possible reason for the difference in biological activity between these analogues may be the difference in pKa values of the terminal amino groups. The conjugate acid of morpholine has a pKa of 8 , whereas the conjugate acids of pyrrolidine and dimethylamine have $p K a$ values of $11 .{ }^{20}$

The remaining series I analogues consisted of more dramatic structural changes, such as replacing the tertiary amine with an ether (82 and 83 ) or alcohol (84 and 85 ) functionality, saturation at carbons 15-16 (83 and 85), and removal of the methyl substituent at carbon 15 . All of these analogues showed a large decrease in activity (approximately 500-fold) in all cell lines. ${ }^{2}$ Unfortunately, none of the modifications with simplified, or partially saturated side chains were prepared with the dimethylamine terminal group, which may have accounted for the lack of biological activity. 


\subsubsection{Simplified Triazole-Containing Analogue Prepared by Cumming}

Although the thiazole ring is part of the binding domain proposed by Romo (Figure 1.7) ${ }^{14}$ there has been no experimental evidence to show that this heterocyclic functionality has a role in binding to the biological target.

In 2013 a triazole-containing pateamine analogue 96 (Figure 1.11) was synthesised at VUW by former PhD student Hemi Cumming. ${ }^{15}$ The thiazole of pateamine was replaced with a triazole in order to determine whether the thiazole ring is a necessary functional group in pateamine. ${ }^{15}$

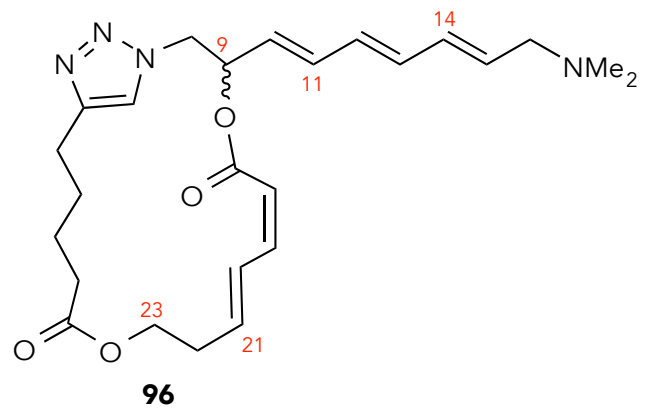

Figure 1.11 Simplified triazole analogue synthesised by Cumming. ${ }^{15}$

This analogue also contained a number of structural simplifications, such as the removal of the amino and methyl functional groups at carbon 3 and 5, respectively, inspired by the DMDA analogue 68. The methyl substituent at carbon 23 was removed to further reduce the number of stereocentres, and the methyl substituents at carbons 11, 14 and 21 were removed to determine if they also played a part in the biological activity of pateamine.

Four fragments were prepared for the synthesis of 96: the commercially available 6-heptanoic acid (97), lactone 98, tri-substituted propane 99, and aldehyde 100 (Figure 1.12). 


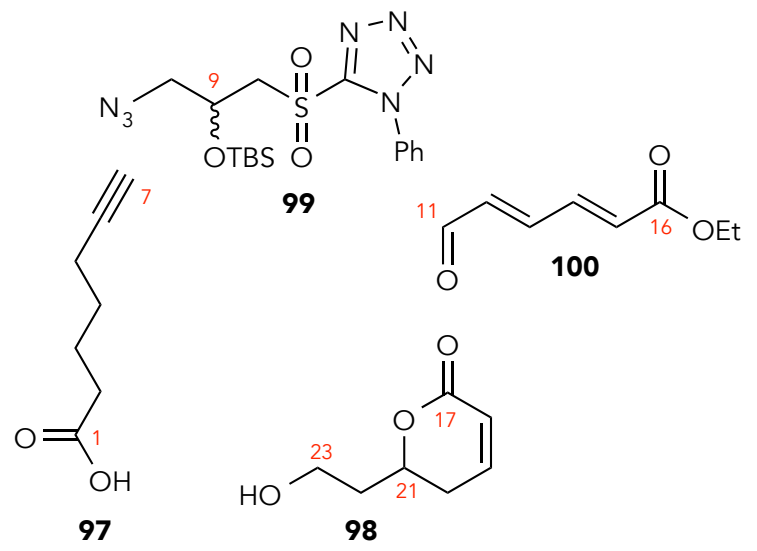

Figure 1.12 Fragments for the synthesis of simplified triazole analogue $96 .{ }^{15}$

\section{Synthesis of 6-Heptanoic Acid 97}

6-Heptanoic acid (97) is commercially available; however, a synthesis for this fragment was established by Cumming from $\varepsilon$-caprolactone (101) using the Ohira-Bestmann reagent 104, providing an overall yield of $58 \%$ (Scheme 1.13). ${ }^{15}$

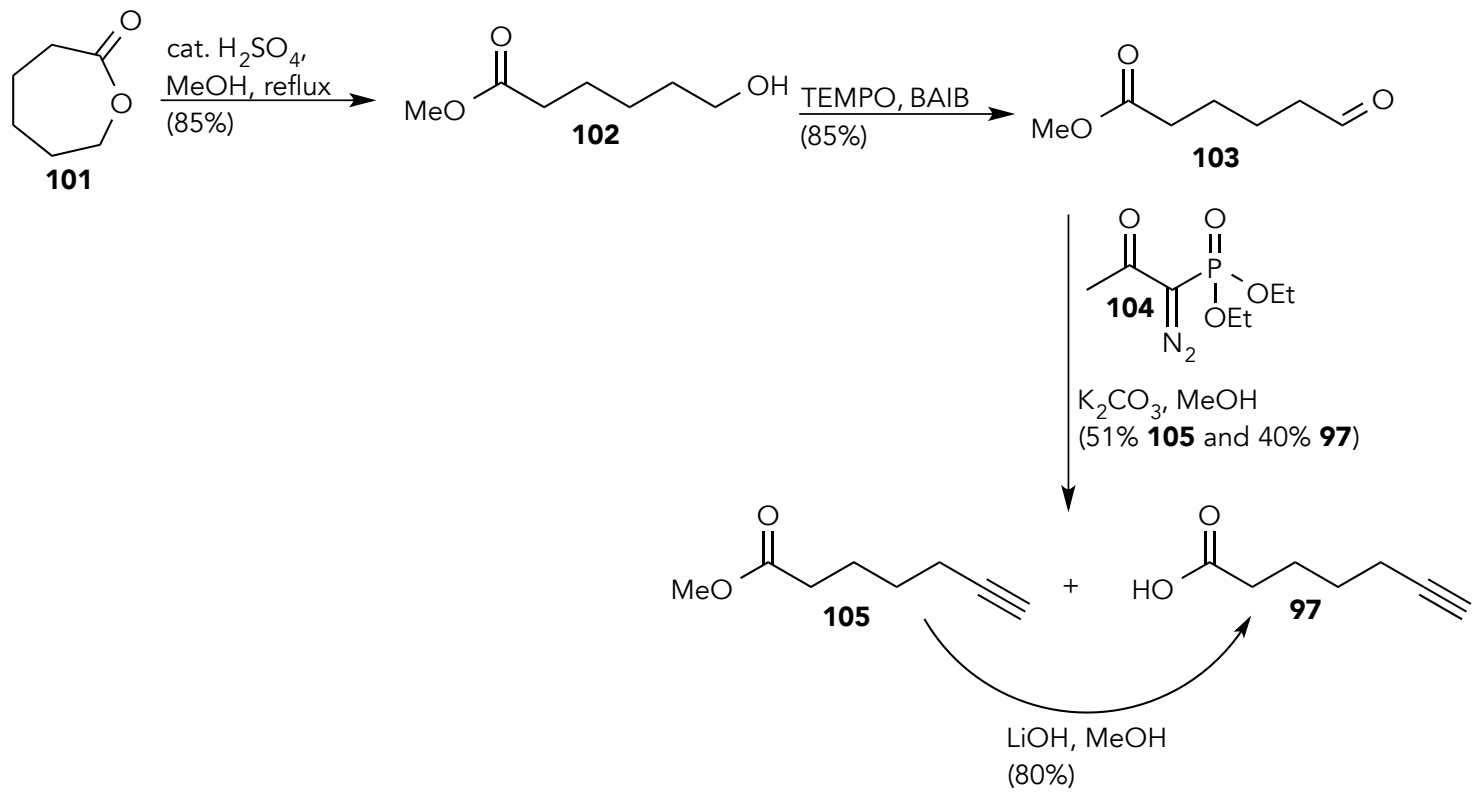

Scheme 1.13 Synthesis of fragment $97 .^{15}$

TEMPO = 2,2,6,6-tetramethylpiperidine-1-oxyl, BAIB = bis(acetoxy)iodobenzene. 
A solution of 1,3-propanediol (106) was heated in a Dean-Stark apparatus with paraanisaldehyde to afford cyclic acetal 107 (Scheme 1.14). ${ }^{15}$ The para-methoxybenzyl (PMB) ether protecting group was used for this fragment due to the benefit of being able to mono-protect the diol 106 via a cyclic acetal, as well as the added benefit of containing a chromophore to facilitate ultra-violet (UV) visualisation on thin layer chromatography (TLC).
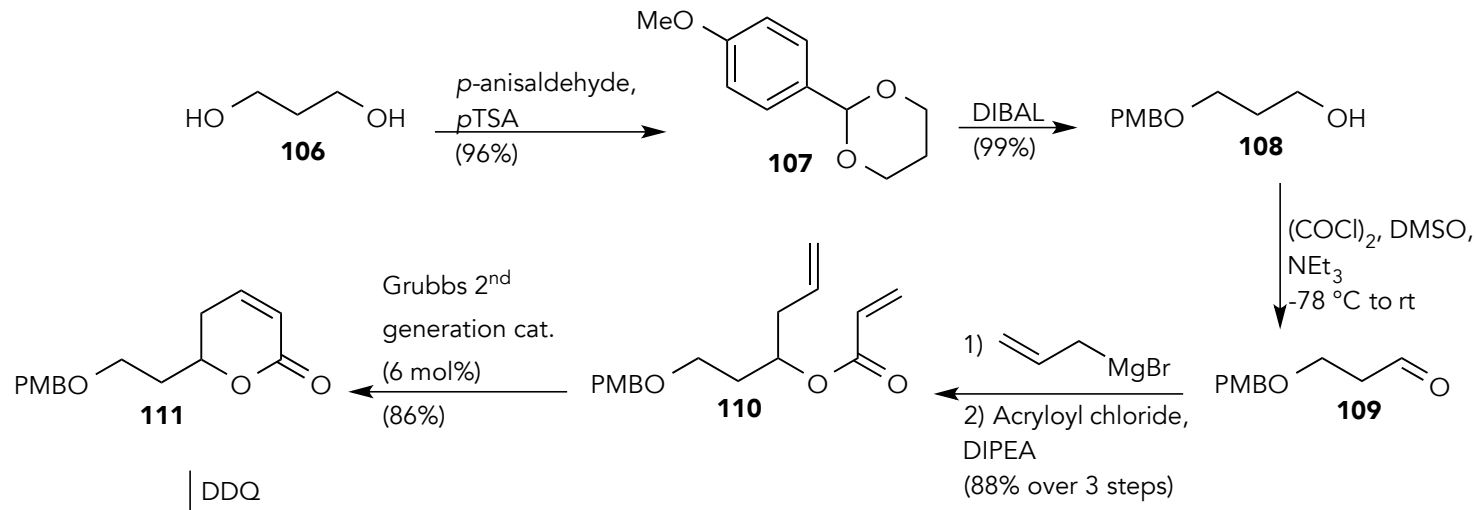<smiles>O=C1C=CCC(CCO)O1</smiles>

(88\% over 3 steps)

Scheme 1.14 Synthesis of fragment $98 . .^{15}$

Reductive cleavage of 107 followed by a Swern oxidation provided the aldehyde 109. The one pot synthesis of 110 was achieved by a Grignard reaction with allylmagnesium bromide, followed by acryloylation of the resultant alcohol. Ring closing metathesis using Grubbs $2^{\text {nd }}$ generation catalyst afforded 111, which was then treated with 2,3-dichloro-5,6-dicyano-1,4benzoquinone (DDQ) to afford the desired lactone 98 in an overall yield of $60 \% .^{15}$

\section{Synthesis of Tri-Substituted Propane 99}

As the attachment of 1,2,3-tri-substituted propane 99 to aldehyde 100 was to be achieved via a Julia-Kocienski reaction during side chain formation, the installation of a phenyltetrazolylsulfone moiety onto the propane framework was essential. 
The synthesis of tri-substituted propane 99 started with epoxide opening of epichlorohydrin (112) with mercaptophenyltetrazole 113 (Scheme 1.15). The alkyl chloride of 114 was then substituted by an azide to afford 115. Silyl protection of the hydroxyl group was followed by oxidation of the thioether to provide the sulfone 99 in an overall yield of $63 \% .{ }^{15}$

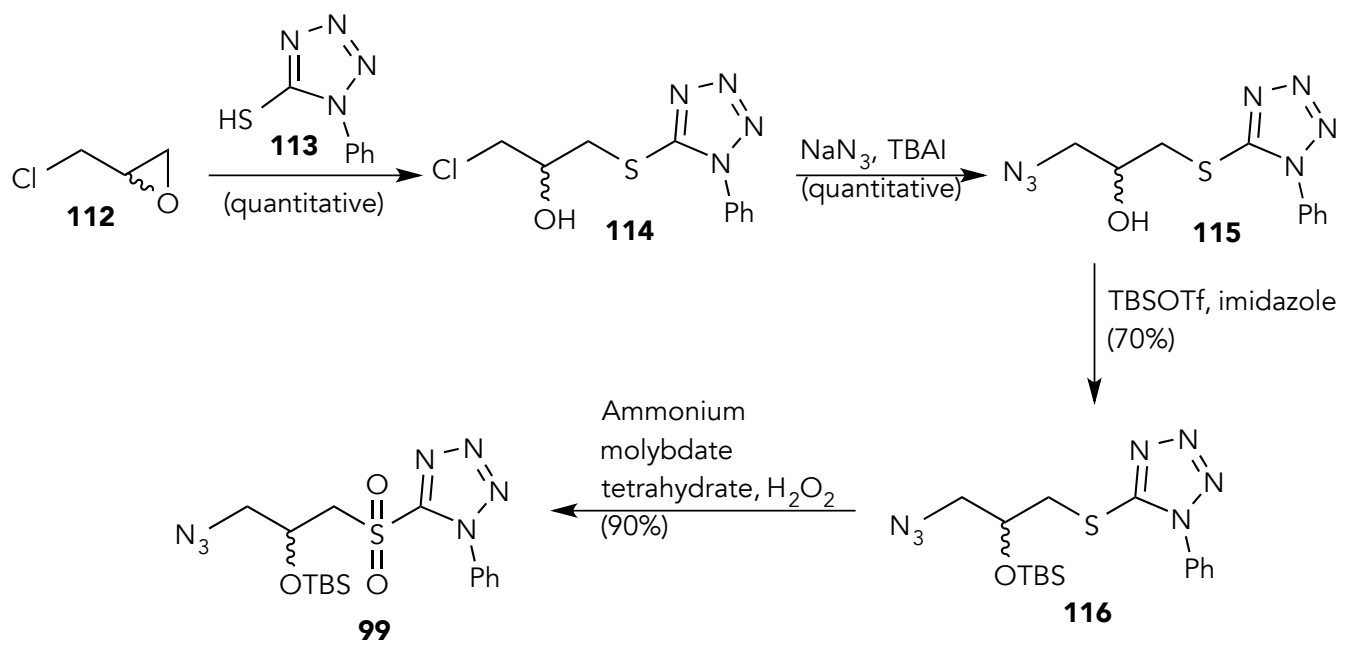

Scheme 1.15 Synthesis of fragment $99 . .^{15}$

The synthesis of side chain fragment 100 started with oxidative ring opening of furan with bromine and methanol to give 118 (Scheme 1.16). Mono-deprotection using Amberlyst 15 (a solid supported sulfonic acid) at room temperature, followed by Wittig olefination with ylide 120 afforded E,E-diene 121 . Finally treatment with Amberlyst 15 at $60^{\circ} \mathrm{C}$ gave the desired aldehyde 100 in a $46 \%$ overall yield. ${ }^{15}$ 

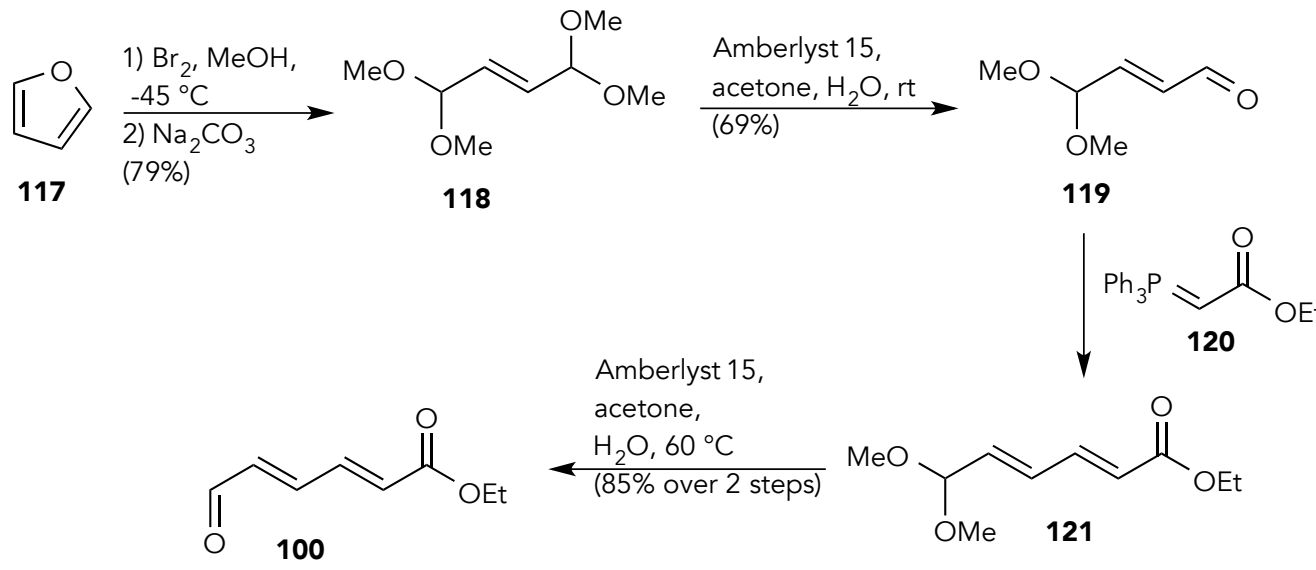

Scheme 1.16 Synthesis of $100 .^{15}$

\section{Coupling of Fragments 99 and 100 to Form Conjugated Trienyl Azide 125}

The sulfone 99 was coupled to aldehyde 100 via a Julia-Kocienski reaction to give 122 (Scheme 1.17). The ethyl ester was fully reduced and then partially oxidised to afford aldehyde 124. Finally, desilylation led to the final conjugated trienyl azide 125; this reaction was only conducted for 2 hours, as there were concerns of potential acid-catalysed elimination of the hydroxyl group, giving an undesired conjugated tetraene..$^{15}$

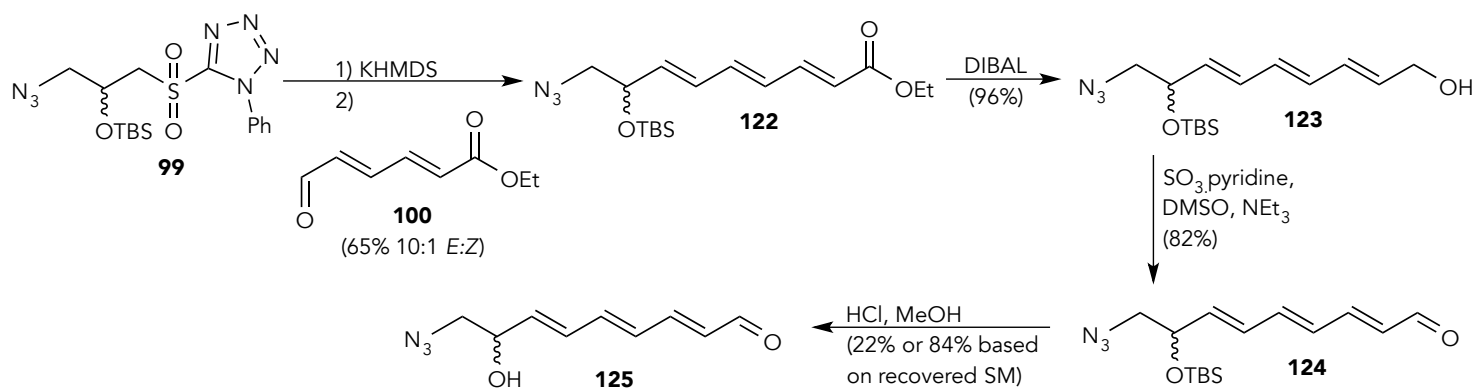

Scheme 1.17 Synthesis of conjugated trienyl azide $125 . .^{15}$

\section{Completion of the Synthesis of Triazole-Containing Analogue 96}

The first stage of the completion of 96 was the coupling of lactone 98 to 97 via a modified Steglich esterification using $N$-(3-dimethylaminopropyl)- $N$ '-ethylcarbodiimide (EDCI) to afford 126 (Scheme 1.18). Treatment of 126 with tetrabutylammonium fluoride (TBAF) gave the Z,Edienoic acid 127 as a single geometric isomer. Coupling of alkyne 127 and azide 125 was 
achieved via copper-catalysed azide-alkyne cycloaddition to provide triazole 128. Yamaguchi macrolactonisation afforded the macrocycle 129 with no observable geometric isomer in the ring-closed product. The low yield of this reaction was presumed to be a consequence of performing the reaction at low temperature, with a short reaction time, and using catalytic amounts of 4-dimethylaminopyridine (DMAP) to prevent isomerisation of the $Z, E$-dienoate. ${ }^{15}$ Finally, reductive amination converted aldehyde 129 to the desired triazole-containing analogue 96 with an overall yield of $0.6 \%$, or $2 \%$ yield based on recovered starting material, over 11 steps for the longest linear sequence. ${ }^{15}$

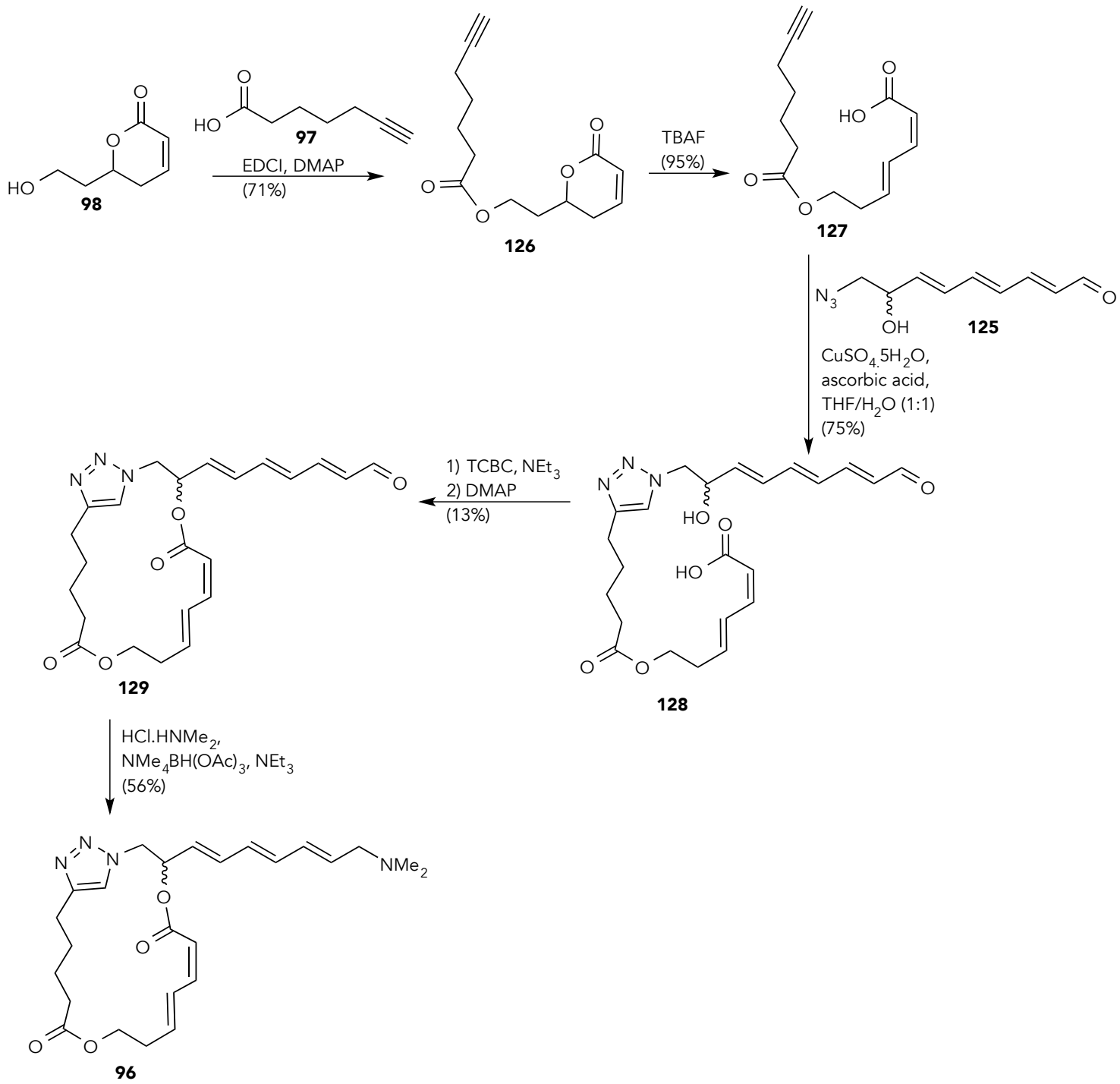

Scheme 1.18 Connecting fragments 97,98 and 125 for the completion of the synthesis of $96 .{ }^{15}$

Overall this synthesis employs easily accessible and cheap starting materials. The use of (R)-(-)epichlorohydrin would provide the natural configuration at carbon 9 in a non-racemic 
analogue; however, for the research undertaken by Cumming only the racemic analogue was synthesised.

\section{Biological Activity of Triazole-Containing Analogue}

The triazole analogue showed low biological activity, with $\mathrm{IC}_{50}$ values of $34.6 \mu \mathrm{M}$ and $51.1 \mu \mathrm{M}$ in HL-60 (human promyelocytic leukaemia) and 1A9 (human ovarian carcinoma) cells, respectively, ${ }^{15}$ compared to pateamine with a range of $\mathrm{IC}_{50}$ values of 1.4-2.0 nM in HL-60, HeLa and SH-SY5Y (human neuroblastoma derived cells) cell lines. ${ }^{21}$ As the biological activity displayed in the triazole-containing analogue was substantially lower than that of pateamine, it is necessary to determine whether the loss of biological activity was primarily due to the loss of the thiazole functional group, or due to the removal of the methyl groups at carbons 11, 14, 21 and 23.

A possible reason for the low biological activity of the triazole-containing analogue when compared to pateamine and the DMDA analogue is the difference in electrostatic potential between the triazole and thiazole groups (Figure 1.13). The electrostatic potential of the triazole (top right image circled) is negative, whereas the thiazole (bottom right image circled) electrostatic potential is neutral. ${ }^{15}$

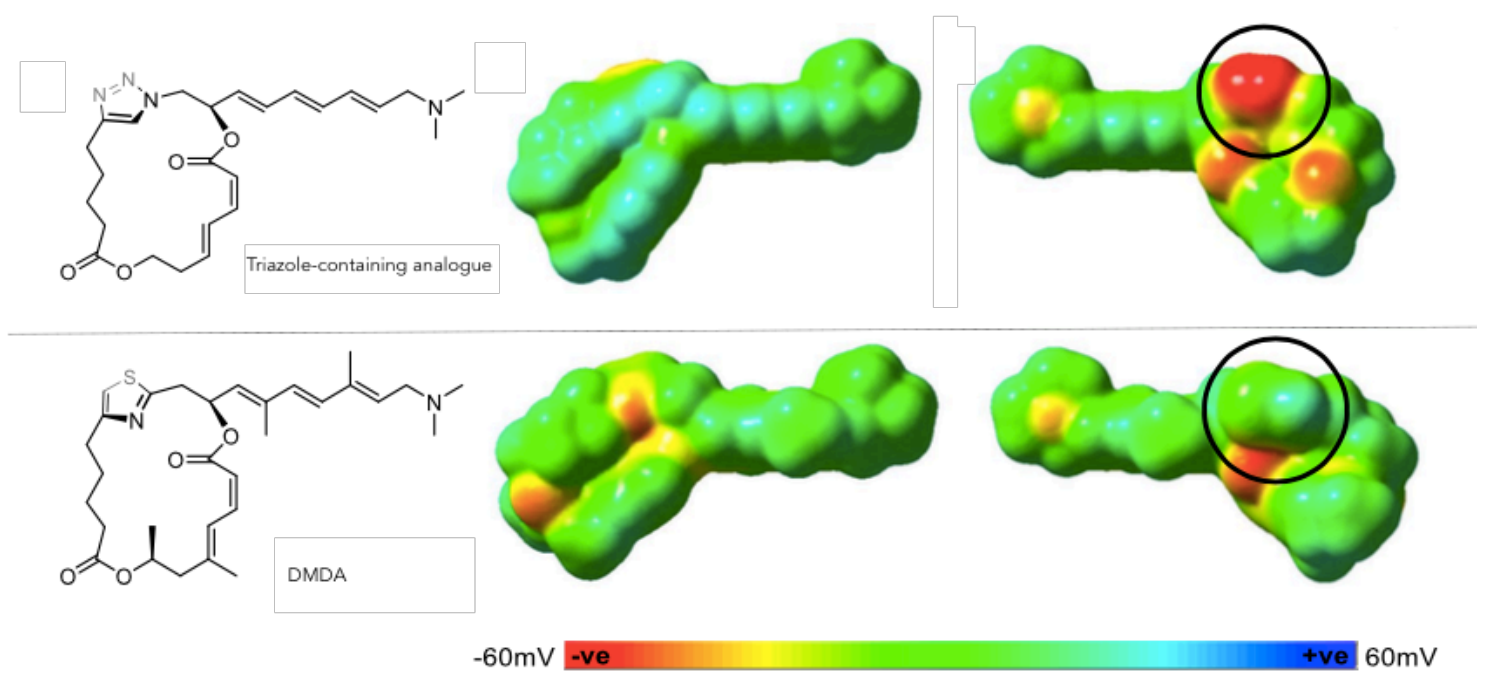

Figure 1.13 Calculated electrostatic potential surfaces of the triazole-containing analogue and DMDA (modified from Cumming). ${ }^{15}$ 
Another reason for the lack of biological activity of 96 may be the reduced basicity of a triazole compared to a thiazole functional group..$^{15}$ For example, the conjugate acid of 2,5dimethylthiazole has a pKa value of 3.91, ${ }^{22}$ whereas the conjugate acid of 1-methyltriazole has a pKa value of $1.25 .^{20}$ This decreased basicity of the triazole suggests that it will be less readily protonated under physiological conditions; should protonation be required for pateamine to display a high biological activity, this would account for the low biological activity of 96 . Alternatively, the reduction in biological activity may arise from a loss of metabolic stability or key binding interaction arising from the absence of one or more methyl groups.

\subsection{Biological Activity of Pateamine and Analogues}

\subsubsection{Initial Biological Studies of Pateamine and Analogues}

The initial biological activity of pateamine, reported in 1991, showed selective inhibitory activity towards cancer cell lines, with an $\mathrm{IC}_{50}$ value of $0.27 \mathrm{nM}$ in the P388 leukaemia murine fast growing cell line, compared to a cell line grown under static growth conditions $\left(\mathrm{IC}_{50}\right.$ value of $540 \mathrm{nM}) .{ }^{1}$ These initial results showed that pateamine is a potent and selective anticancer lead.

Early biological testing of pateamine in 1998 and the DMDA analogue in $2004^{14}$ by Romo and colleagues suggested that both compounds are immunosuppressive. ${ }^{11}$ An IL-2 reporter gene assay using Jurkat $T$ cells was performed on pateamine and the DMDA analogue, which measured their ability to block the activation of an IL-2 promoter attached to a luciferase reporter gene. The results showed that pateamine and the DMDA analogue inhibit T-cell receptor-mediated IL-2 transcription; ${ }^{11}$ however, the immunosuppressive activity seen may have been due to antiproliferative activity instead, as the IL-2 reporter assay was cell-based. ${ }^{2}$

A re-evaluation of the biological activity of pateamine and DMDA pateamine was reported in $2014,{ }^{2}$ resulting from new insights into the biological target of pateamine (see Section 1.5.2). Both compounds were tested for proliferation inhibition activity in a variety of human cell lines, such as HeLa, HaCaT (keratinocyte), Jurkat T and RKO (colon carcinoma) cell lines, and both pateamine and DMDA pateamine showed potent cytotoxic effects in all of these cell lines. ${ }^{2}$ These results may invalidate the previous conclusion that pateamine and DMDA pateamine are 
immunosuppressive, ${ }^{11}$ as IL-2 transcription relies on the proliferation of Jurkat T cells, as well as the translation of the luciferase reporter gene. ${ }^{2}$

\subsubsection{Discovery of the Biological Target of Pateamine}

In 2005 two separate research groups, Pelletier and co-workers, ${ }^{23}$ and Liu and colleagues, ${ }^{24}$ discovered that the biological target of pateamine was the eukaryotic initiation factor 4A (elF4A) isoforms: elF4AI, elF4AIl and elF4AIII. ${ }^{23,24}$

Liu and co-workers discovered the molecular mechanism of action of pateamine using an affinity binding assay. ${ }^{24}$ These were performed using pateamine-biotin conjugates bound to streptavidin-Sepharose on various cell lysates (RKO, HeLa, wheat germ extract, and rabbit reticulocyte lysates). The elF4A protein was bound to the pateamine-biotin conjugate in all cell lysates, as determined by MALDI-TOF mass spectrometry. Treatment of HeLa cells that overexpress elF4A with pateamine led to a five-fold decrease in the bioactivity of pateamine. ${ }^{24}$ These results suggest that elF4A is the primary mediator of cell proliferation inhibition by pateamine.

Pelletier and co-workers discovered potent translation inhibitory activity associated with pateamine during a high-throughput screening campaign to identify eukaryotic protein synthesis inhibitors. ${ }^{23}$ The biological target of pateamine was identified using affinity chromatography, in which total cell extracts prepared from HL-60 cells were loaded onto an affinity matrix containing pateamine covalently bound to Sepharose beads. Proteins that were retained on the resin were separated and visualised using sodium dodecyl sulfate polyacrylamide gel electrophoresis. The pateamine resin retained elF4AI, elF4AII and elF4AIII, showing that these proteins are the biological targets of pateamine. ${ }^{23}$ The HL-60 cell extracts and eluents from the pateamine resin were probed for the presence of elF4B, elF2 $\alpha$ and elF4E; however, none of these proteins were retained on the pateamine resin, thus determining that pateamine selectively targets the elF4A isoforms. ${ }^{23}$

More recently an affinity chromatography study by Teesdale-Spittle and colleagues using HeLa and SH-SY5Y cell lines showed that pateamine bound to elF4A, as well as actin and tubulin. ${ }^{21}$ 


\subsubsection{Role of elF4A and Inhibition of elF4A by Pateamine}

Translation is the process in which the messenger RNA (mRNA) is decoded by ribosomes to produce proteins for the cell. Translation initiation, and more specifically ribosome recruitment, is a major site of regulatory control. ${ }^{25}$ Recruitment of ribosomes near the $5^{\prime}$ cap structure of mRNA is facilitated by the elF4F complex, ${ }^{23,26}$ which is comprised of three initiation factors: elF4E, elF4G, and elF4A. The role of elF4A within the elF4F complex is to unwind secondary structure in the $5^{\prime}$ untranslated region (UTR) of mRNA, allowing ribosome recruitment and thereby initiating translation. ${ }^{23}$

The elF4A protein exists in an open form, which resembles a dumbbell structure consisting of compact $\mathrm{N}$ - and $\mathrm{C}$ - terminal domains connected by a flexible linker, ${ }^{27,28}$ and a closed form. ${ }^{29}$ The open form is favoured in the absence of ATP and RNA, whereas in the presence of ATP and RNA the closed form is favoured. ${ }^{29}$ In this closed form, bound single-stranded RNA is bent and its arrangement in the binding site of elF4A is not compatible with double-stranded RNA. ${ }^{29}$ It is this effect of the closed form of elF4A that leads to the conversion to singlestranded RNA, and the unwinding of secondary structure in the $5^{\prime}$ UTR of the mRNA transcript. ${ }^{29}$ This activity of elF4A is promoted by the other members of the elF4F complex; specifically elF4G, which binds to eIF4E and eIF4A and bridges the ribosome to the mRNA through its interaction with elF3. ${ }^{23,26}$

Pateamine stimulates the interaction between elF4A and mRNA, thus reducing the amount of elF4A available to the elF4F complex. Pateamine also induces the recruitment of the pateamine-elF4A-mRNA complex into stress granules. ${ }^{30,31}$ These events lead to inhibition of translation initiation, and ultimately cell death resulting from an inability to synthesise proteins.

Stress granules are formed when a cell encounters stress such as heat, oxidative conditions, UV irradiation, or hypoxia. This occurs as a defence mechanism for the cell, as its continued survival depends on prioritising the translation of mRNAs encoding enzymes that are involved in damage repair over housekeeping proteins. ${ }^{32,33}$ These stress granules are cytoplasmic complexes containing non-translating mRNAs, translation initiation factors, and other proteins involved in mRNA translation. ${ }^{33,34}$ 


\subsubsection{Potential Therapeutic Benefits of Pateamine}

Rapid cell proliferation is associated with many types of cancers and is often accompanied by deregulation of translation; ${ }^{35}$ therefore, an inhibitor of translation initiation, such as pateamine, would be an attractive candidate for cancer therapeutics, and several studies previously discussed have shown that pateamine is a potent anticancer lead. ${ }^{1,2,21,36}$ Recent research has shown other potential therapeutic benefits of pateamine, such as a possible treatment for Alzheimer's disease, ${ }^{37}$ prevention of cachexia, ${ }^{30}$ and inhibition of influenza A. ${ }^{38}$

\section{Alzheimer's Disease}

In 2010 Spriggs and co-workers showed that the inhibition of elF4A may be useful in the treatment of Alzheimer's disease. ${ }^{37}$ Alzheimer's disease is characterised by the presence of extracellular plaques of amyloid-beta, synthesised by amyloid precursor protein (APP), and intracellular neurofibrillary tangles of tau protein. ${ }^{39}$ Reducing the levels of APP and tau has been shown to slow the progress of Alzheimer's disease in animal models..$^{37,40}$

The 5' UTRs of APP and tau are long and structured, and form a barrier to the initiating ribosome during translation; thus, they are more dependent on translation initiation factors such as elF4A than housekeeping genes are, which usually have short, unstructured 5' UTRs. ${ }^{37}$ When an elF4A inhibitor similar to pateamine was used at low concentrations, that are not growth inhibitory, the translation of transcripts with more structured 5' UTRs, such as APP and tau, were preferentially inhibited. ${ }^{37}$ This led to a reduced synthesis of APP and tau, while the synthesis of proteins from transcripts with less structured 5' UTRs, such as housekeeping genes, were not affected. ${ }^{37}$

\section{Cachexia}

In 2012, Di Marco and colleagues showed that pateamine prevented cachexia-induced muscle wasting in mice. ${ }^{30}$ Cachexia is a disorder characterised by excessive weight loss and muscle wasting, which often affects individuals with cancer, AIDS, chronic obstructive pulmonary disease and sepsis. ${ }^{30,41,42}$ 
Several pro-inflammatory cytokines have been shown to induce muscle wasting in patients with cancer or chronic inflammation; these are interferon $\gamma$ and tumour necrosis factor $\alpha$, which both activate the nuclear factor NF- $\kappa \mathrm{B} .{ }^{30}$ Activation of NF- $\kappa \mathrm{B}$ leads to decreased expression of MyoD and Myogenin, which are required for the formation and maintenance of muscle fibres. ${ }^{43}$ Activation of NF- $\kappa \mathrm{B}$ also increases the levels of nitric oxide, which is normally secreted by cells to defend against pathogenic infections, and leads to oxidative stress and muscle wasting. ${ }^{44}$ Nitric oxide is produced from the enzyme inducible nitric oxide synthase (iNOS), which in turn is stimulated by interferon $\gamma$, tumour necrosis factor $\alpha$ and NF- $\kappa$ B..$^{30,41}$

In low doses, pateamine prevents cachexia by inhibiting the production of iNOS, while rescuing the expression of MyoD and Myogenin. It does this by promoting the association of elF4A with iNOS mRNA, and its recruitment to stress granules where the iNOS mRNA cannot be translated. In contrast, the MyoD and Myogenin mRNAs are not recruited to stress granules and can continue to be translated. ${ }^{30}$ These low doses of pateamine were well tolerated in vivo, with no observed distress or effect on body weight in mice. ${ }^{30}$

\section{Influenza A}

In 2014, McCormick and co-workers showed that pateamine inhibits influenza A viral protein and genomic RNA synthesis. ${ }^{38}$ Influenza A virus (IAV) mRNAs are similar to host mRNAs; however, these gain preferential access to cap-dependent translation in the host through a host shut off mechanism, which is initiated by the viral non-structural protein 1 (NS-1) and polymerase-acidic protein-X. ${ }^{38}$ As IAV mRNA is reliant on the host's translational machinery, it is vulnerable to translation initiation inhibiting drugs, such as pateamine. ${ }^{38}$ IAV inhibits the formation of stress granules, both dependently and independently of NS-1;38,45 however, at early stages of the infection IAV is susceptible to translation initiation inhibition and stress granule formation. McCormick and co-workers showed that treatment of cells with pateamine at an early stage of influenza A viral infection induced stress granule formation, and inhibited IAV replication by increasing the association of IAV mRNA to elF4A, thus preventing the translation of essential proteins for viral replication. ${ }^{38}$ 


\subsection{Summary}

Pateamine (1, Figure 1.4) is a potent and selective anticancer lead ${ }^{1}$ and antiviral agent. ${ }^{38,45}$ Pateamine also has therapeutic potential for treatment of Alzheimer's disease ${ }^{37}$ and prevention of cachexia. ${ }^{30}$ This is due to its inhibition of the eukaryotic initiation factor $4 \mathrm{~A}$ (elF4A), which leads to the formation of stress granules, and the inhibition of translation of transcripts with highly structured 5' UTRs.

The total synthesis of pateamine was achieved by two research groups, Romo and Pattenden in overall yield of $0.2 \%$ in greater than 20 steps for the longest linear sequence. ${ }^{11,13}$ Romo and colleagues hypothesised that pateamine consists of a separate binding and scaffolding domain, which led to the synthesis of a simplified DMDA analogue that possessed similar biological activity to pateamine. ${ }^{2,14} \mathrm{~A}$ highly simplified analogue of pateamine was synthesised by Cumming in 2013 , in which the thiazole was replaced with a triazole. ${ }^{15}$ As the biological activity of this analogue was low, it is necessary to determine if the lack of biological activity was due to the replacement of the thiazole, or due to removal of the methyl substituents at carbons 11, 14, 21 and 23, or from a combination of these modifications. 


\section{CHAPTER TWO: RESEARCH AIMS}

It was hypothesised that the lack of biological activity of the triazole-containing analogue 96 , synthesised by Cumming (Section 1.4.4), ${ }^{15}$ was largely due to the replacement of the thiazole with a triazole. Reasons for the lack of biological activity may be the difference of electrostatic potential between the triazole and thiazole, or the reduced basicity of a triazole compared to a thiazole. ${ }^{15}$

A highly simplified side chain-free thiazole-containing analogue 130 (Figure 2.1), devoid of the carbon 3 amino and carbon 5 methyl groups, as seen in the DMDA analogue 68 (Figure 1.8), and the methyl groups at carbons 15 and 17, as seen in the triazole-containing analogue 96 (Figure 1.11), will be synthesised. This will lay the groundwork for a subsequent synthesis of a thiazole-containing analogue of 96 to determine if the lack of biological activity of 96 was due to the replacement of the thiazole with a triazole.

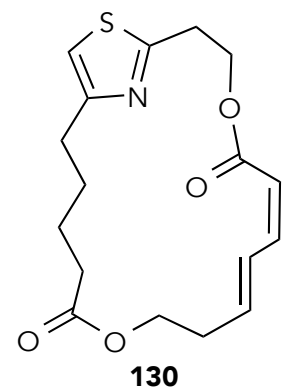

Figure 2.1 Proposed highly simplified side chain-free analogue 130 .

While Romo and colleagues have previously shown that the side chain of pateamine is essential for biological activity, ${ }^{2}$ there have been no studies to establish whether this loss of biological activity was due to a failure to bind to elF4A, or whether binding continues to occur, but does not elicit a functional response. Analogue 130 will be used to investigate whether the thiazole-containing bis-lactone core of analogue 96 retains affinity for the elF4A target.

The synthesis of the side chain-free thiazole analogue 130 will also allow for the evaluation of synthetic methodology, particularly a new approach to the thiazole formation, as well as to understand the reasons for the low yielding Yamaguchi macrolactonisation seen in the synthesis of 96 by Cumming (Scheme 1.18). This methodology can then be used to synthesise side chain-containing analogues in the future. 


\subsection{Synthetic Strategy for Analogue 130}

The analogue 130 will be synthesised from the commercially available 6-heptanoic acid (97), lactone 98, prepared from 1,3-propanediol (106), and thioamide 131, synthesised from 3hydroxypropionitrile (132) (Scheme 2.1).

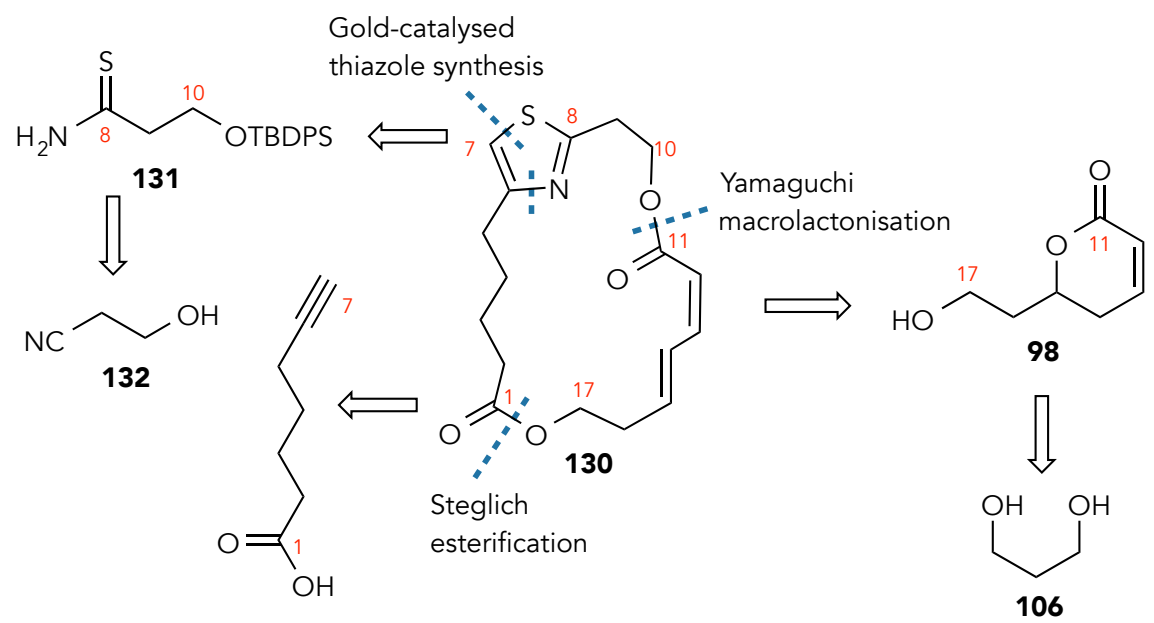

97

Scheme 2.1 Retrosynthetic strategy of analogue 130.

Heptanoic acid 97 and lactone 98 will be linked together via a modified Steglich esterification, as seen in the synthesis of 96 by Cumming (Scheme 1.18). ${ }^{15}$ The thiazole will be synthesised from the thioamide 131 and the alkyne functionality of 6-heptanoic acid (97) through a gold-catalysed thiazole formation. Subsequent desilylation and eliminative opening of the $\delta$-lactone functionality to a Z,E dienoate will be followed by a modified Yamaguchi macrolactonisation to afford the analogue 130 .

Based on literature precedence, ${ }^{2}$ analogue 130 should not inhibit cell growth, as it is devoid of the side chain that is part of the proposed binding domain of pateamine $i^{14}$ however, analogue 130 may bind to the biological target of pateamine, elF4A, without eliciting a functional response. This will be investigated through a competitive bioactivity assay, by treating 1A9 (human ovarian carcinoma) cells to analogue 130 followed by pateamine, and determining cell viability using an MTT assay. 


\section{CHAPTER THREE: RESULTS AND DISCUSSION}

Discussed in this chapter is the synthetic work on the key fragments, lactone 98 and thioamide 131 (Figure 3.1), and the coupling of these fragments, along with 6-heptanoic acid (97), to provide the side chain-free pateamine analogue 130. The activity of analogue 130 in inhibiting the growth of cancer cells was also determined using an MTT assay on a 1A9 cell line, and the binding of analogue 130 to the biological target of pateamine, elF4A, was investigated indirectly through a competitive bioactivity assay with pateamine.
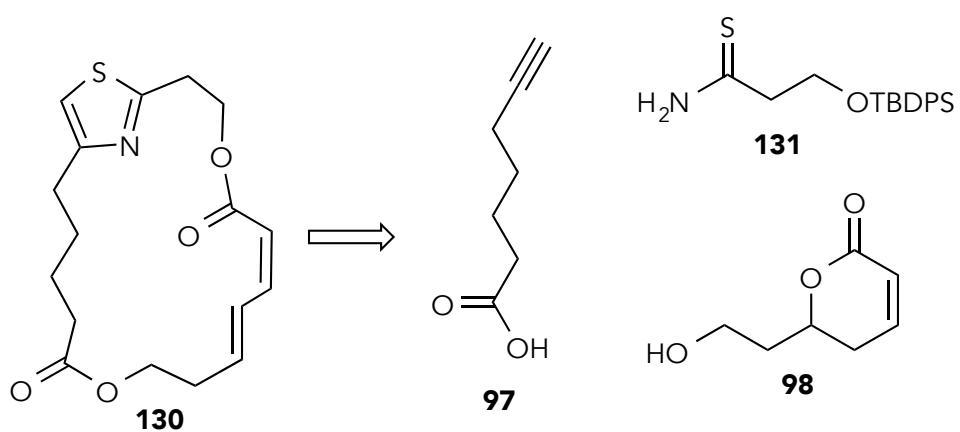

Figure 3.1 Fragments 97,98 and 131 for the synthesis of analogue 130 .

The challenges of this project were to establish methodology for the formation of the thiazole ring, as well as improve the Yamaguchi macrolactonisation, which was observed by Cumming to be low yielding. ${ }^{15}$ While a successful thiazole formation was achieved, the Yamaguchi macrolactonisation was again low yielding, with some isomerism of the Z,E-dienoate moiety observed. Work has also been conducted towards establishing methodology for a side chaincontaining analogue of 130 , which can be used to compare the biological results of the triazole-containing analogue 96 synthesised by Cumming. ${ }^{15}$

\subsection{Fragment Synthesis for Analogue 130}

\subsubsection{Synthesis of Lactone Fragment 98}

As discussed in Section 1.4.5, the fragment providing the Z,E-dienoate of the macrocycle, lactone 98, was previously synthesised by Cumming, ${ }^{15}$ and this procedure was largely unchanged for this project. Alcohol 108 was obtained through the mono-protection of 1,3propanediol (106) via the para-methoxyphenyl acetal 107 (Scheme 3.1), which avoided 
inadvertent di-protection of 1,3-propanediol (106). A modification of Cumming's procedure for the oxidation of alcohol 108 to aldehyde 109 was achieved in 94\% yield via a Parikh-Doering oxidation, rather than the Swern oxidation adopted by Cumming. ${ }^{15}$ The benefit of employing a Parikh-Doering oxidation is that it is carried out at ambient rather than sub-zero temperatures, ${ }^{46}$ which can facilitate large-scale synthesis of this fragment. ${ }^{47}$ While the oxidation of 108 proceeded successfully, the following allylation and acryloylation to give 110 were completed in a disappointing $42 \%$ yield over two steps. Cumming obtained 110 in $88 \%$ over three steps ${ }^{15}$ and it is likely that if time had permitted repetition with a fresh batch of allylmagnesium bromide and distilled acryloyl chloride, ${ }^{48}$ a similar yield could have been achieved in the current work.

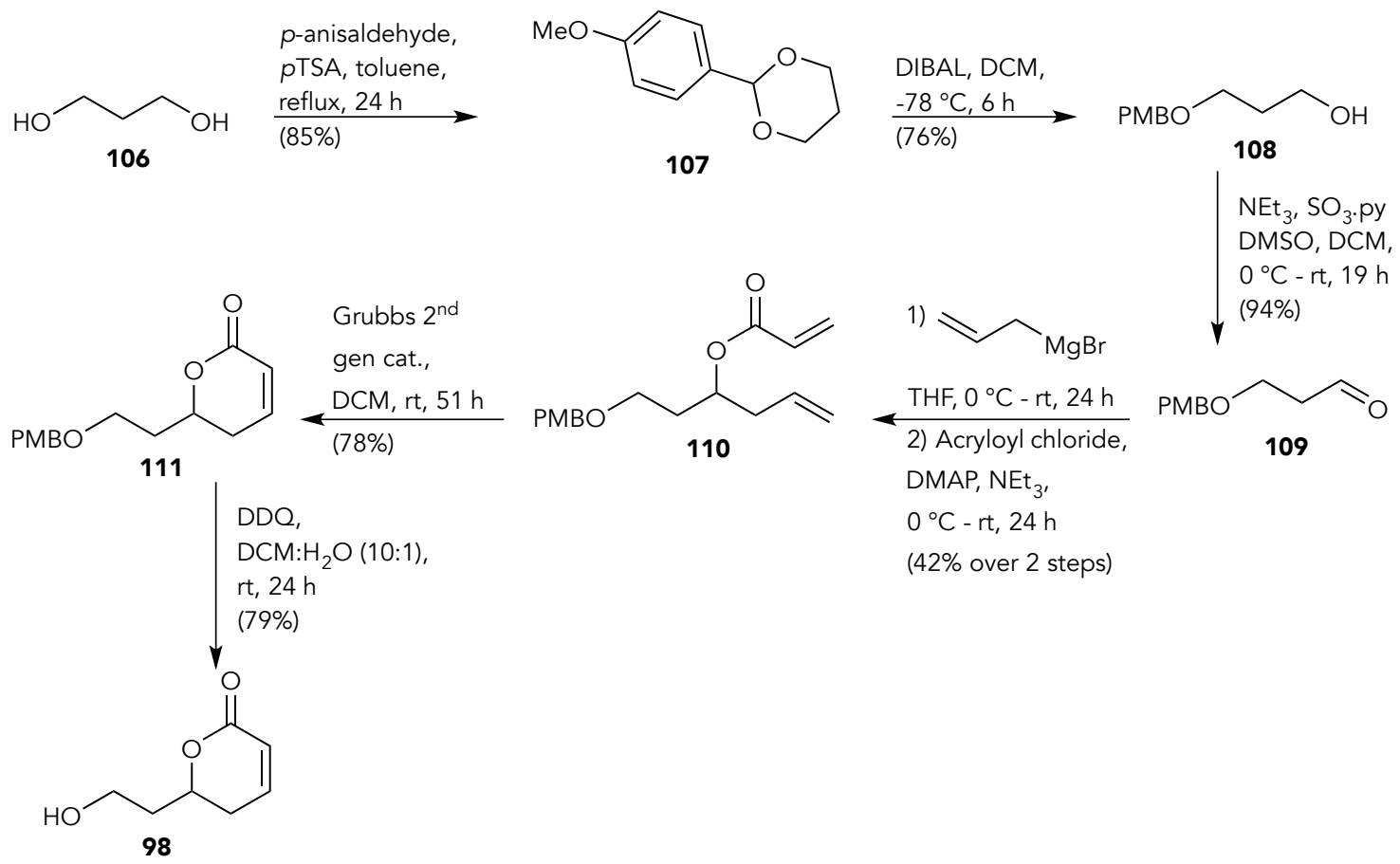

Scheme 3.1 Synthesis of lactone fragment 98.

During deprotection of lactone 111 with DDQ, it was found to be important to avoid a base wash that would typically be used to remove the hydroquinone by-product, as in the presence of base the deprotected lactone 98 was observed to undergo an intramolecular oxa-Michael addition to give 133, the structure of which was determined by ${ }^{1} \mathrm{H}$ and ${ }^{13} \mathrm{C}$ NMR spectroscopy (Figure 3.2). Both the ${ }^{1} \mathrm{H}$ and ${ }^{13} \mathrm{C}$ NMR spectra show a lack of alkene resonances, which would be located around 6.9-6.0 ppm and 145-120 ppm, respectively (based on the ${ }^{1} \mathrm{H}$ and ${ }^{13} \mathrm{C} N M R$ spectroscopy of lactone 98). The ${ }^{1} \mathrm{H}$ and ${ }^{13} \mathrm{C}$ NMR spectra also showed extra oxymethine peaks at 4.3 and 65.4 ppm, respectively, which are not observed in the spectra for lactone 98. 
Jennings and co-workers have also observed this by-product during deprotection of the corresponding tert-butylsilyl (TBS)-protected lactone variant of 111.49

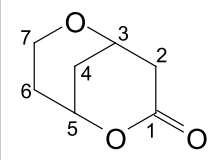

133

${ }^{1} \mathrm{H}$ NMR, $500 \mathrm{MHz}, \mathrm{CDCl}_{3}$

$\mathrm{H}-7$

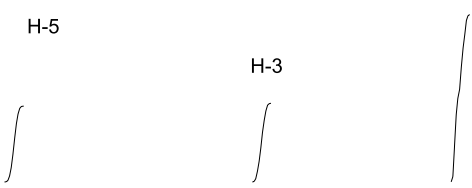

$\mathrm{H}-2$

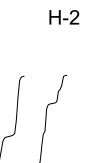

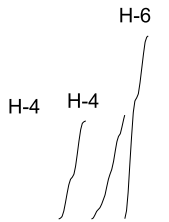
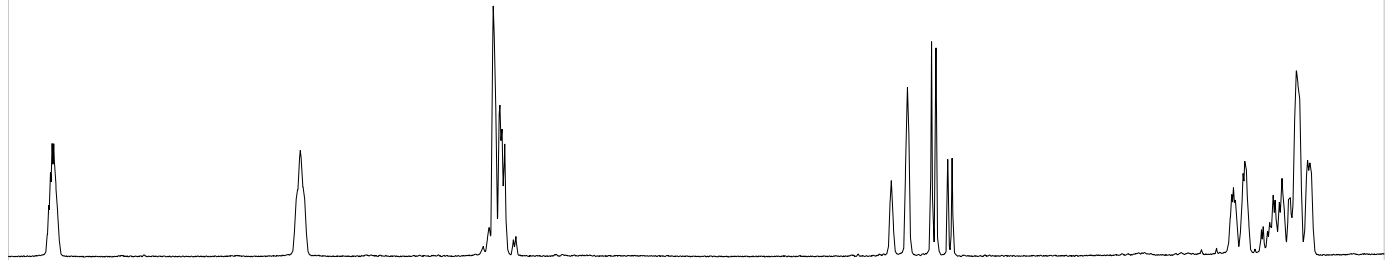

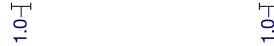
瓷

$04.94 .84 .74 .6 \quad 4.54 .4 \quad 4.34 .24 .14 .03 .93 .8 \quad 3.73 .6 \quad 3.5 \quad 3.43 .3 \quad 3.23 .13 .02 .92 .82 .72 .62 .52 .42 .32 .22 .12 .01 .91 .8$

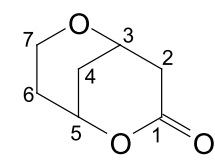

133

${ }^{13} \mathrm{C} \mathrm{NMR}, 125 \mathrm{MHz}, \mathrm{CDCl}_{3}$

C-1

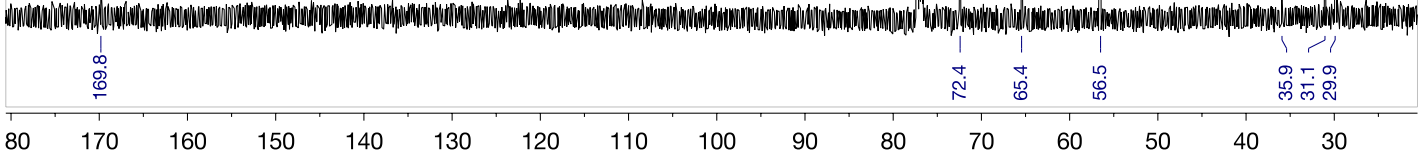

Figure $3.2{ }^{1} \mathrm{H}$ NMR and ${ }^{13} \mathrm{C}$ NMR spectra of by-product 133. Assignments determined by 2D NMR. 
By purifying the product using silica gel column chromatography, rather than a base wash, lactone 98 was produced in an overall 16\% yield from 1,3-propanediol (106). This yield was lower than the $60 \%$ yield achieved by Cumming for the same fragment; ${ }^{15}$ however, it is envisaged that with repetition of the synthesis of 98 , the overall yield would increase to a level close to that which Cumming achieved. It should be mentioned that no effort to control the stereochemistry of this fragment was made, as this stereocentre will be removed later in the synthesis of analogue 130 .

\subsubsection{Synthesis of Thioamide Fragment 131}

The heteroatom-containing portion of the thiazole was installed using the thioamide fragment 131. A key decision for this fragment was the choice of protecting group for the alcohol moiety; as the carbon backbone of 131 is only three carbons long, use of a bulky protecting group to reduce volatility of the fragment was desired. A bulky silyl ether protecting group was chosen for this fragment, in order to make use of the ability for TBAF to simultaneously deprotect this fragment and promote a base-catalysed eliminative opening of the $\delta$-lactone moiety introduced as 98 , thereby forming the required $Z, E$-dienoate functionality of analogue 130. Initially the protecting group used for this fragment was TBS; however, upon treatment with Lawesson's reagent to convert the amide to a thioamide, inadvertent deprotection of the alcohol occurred. By exchanging the TBS group with the bulkier, more robust protecting group tert-butyldiphenylsilyl (TBDPS), the propensity for deprotection was decreased. Thus, the alcohol of 3-hydroxypropionitrile (132) was protected with 1.1 equivalents of TBDPSCI to give 134 (Scheme 3.2). The protected nitrile 134 was then hydrolysed to novel amide 135 using conditions described by Katritzky and co-workers. ${ }^{50}$ Nitriles are usually hydrolysed to amides under acidic conditions, such as $\mathrm{HCl}^{, 51,52}$ which would cause desilylation of $134,{ }^{53}$ or through the use of metal catalysts, ${ }^{54}$ however, Katritzky and co-workers developed a method for conversion of nitriles to amides using basic conditions with $\mathrm{H}_{2} \mathrm{O}_{2}$, dimethyl sulfoxide (DMSO) and catalytic amounts of $\mathrm{K}_{2} \mathrm{CO}_{3} .{ }^{50}$ This hydrolysis was followed by conversion to a thioamide using Lawesson's reagent to give the protected thioamide 131 in an overall yield of $43 \%$ over three steps. 


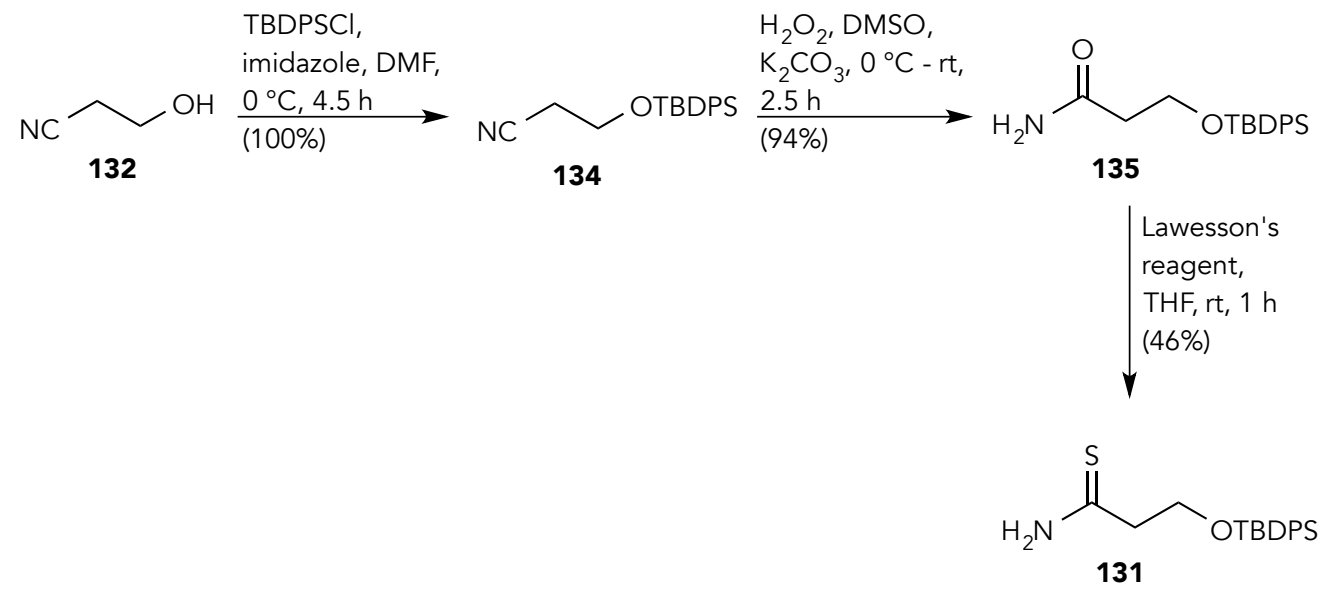

Scheme 3.2 Synthesis of thioamide 131.

Even with a change from TBS to the more robust TBDPS protecting group, some inadvertent deprotection of 135 upon treatment with Lawesson's reagent was still observed, as determined by ${ }^{1} \mathrm{H}$ NMR spectroscopy of a fraction from column chromatography that appears to be predominately TBDPSOH (Figure 3.3), which is consistent with literature values. ${ }^{55}$ Fractions containing a mixture of TBDPSOH and unreacted starting material accounted for approximately $40 \%$ of the recovered material, with any deprotected starting material or product being lost during the aqueous workup, which explains the yield of $46 \%$ for this reaction. 


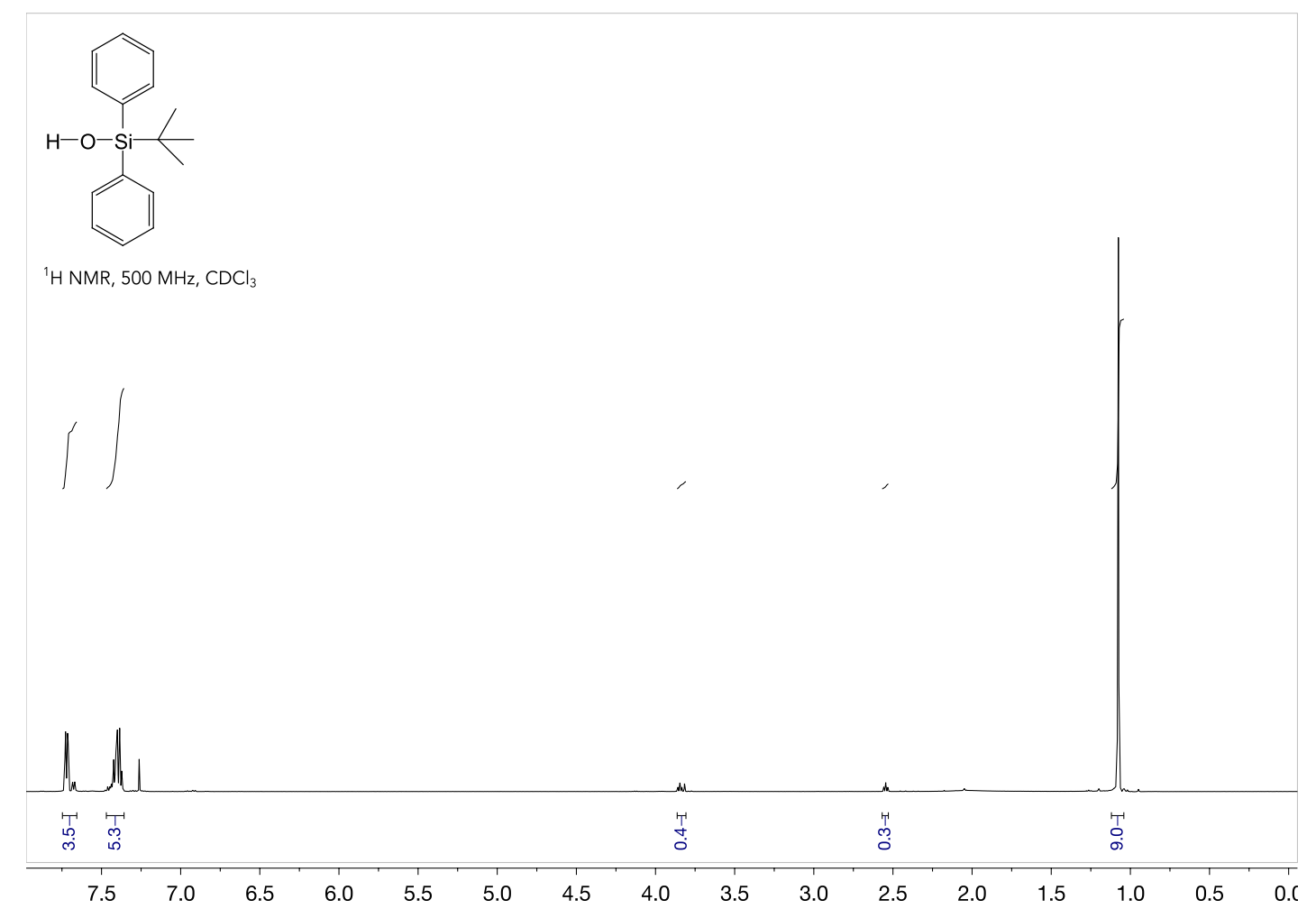

Figure 3.3 Column chromatography fraction showing predominately TBDPSOH from treatment of amide 135 with Lawesson's reagent.

\subsection{Fragment Coupling and Completion of the Synthesis of} Analogue 130

With fragments 97,98 and 131 in hand, completion of analogue 130 was undertaken (Figure 3.4). As planned (see Section 2.1), commercially available 6-heptanoic acid (97) was esterified via modified Steglich conditions with lactone 98 to provide 126, which then formed thiazole 136 through the reaction with thioamide 131 . The benefit of this approach is that 6-heptanoic acid (97) is commercially available, eliminating the requirement to prepare an $\alpha$-haloketone before thiazole synthesis, as required in Romo's approach to the DMDA analogue 68 (Scheme 1.12), which afforded the $\alpha$-haloketone 69 in only $48 \%$ yield over 3 steps. ${ }^{14}$ 


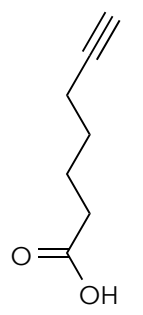

97<smiles>C=CCCCC(=O)OCCC1CCCC(=O)O1</smiles><smiles>C=C(N)CCOCCc1csc(CCCCC(=O)OCCC2CC=CC(=O)O2)n1</smiles>

136<smiles>COCCc1nc(CCCCC(=O)OCC/C=C\C=C/C(=O)O)cs1</smiles>

137

Figure 3.4 Coupling of fragments 97,98 and 131 for the completion of the synthesis of analogue 130 .

\subsubsection{Thiazole Formation Methodology}

Initially, thiazole synthesis was attempted through the condensation of a thioamide with the alkyne portion of 1H-1-(1'-alkynyl)-1,2,3-benziodoxathiole 3,3-dioxide 138 (Figure 3.5) following methods from Togo and Ishiwata; ${ }^{56}$ unfortunately, due to difficulties with purification and characterisation of 138 and its precursors this route was abandoned.

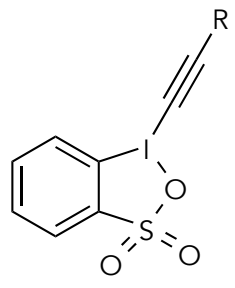

138

Figure 3.5 Structure of $1 \mathrm{H}-1$-(1'-alkynyl)-1,2,3-benziodoxathiole 3,3-dioxide 138, R = alkynyl.

In 2012 Zhang and colleagues discovered that oxidation of a terminal alkyne in the presence of a gold catalyst provided a highly electrophilic $\alpha$-oxo gold carbene, which was so electrophilic that it could abstract chlorine or bromine from the reaction solvent to form $\alpha$ bromo/chloromethyl ketones. ${ }^{57}$ It was later shown that the electrophilicity of the $\alpha$-oxo gold carbene could be reduced through the formation of a tricoordinated gold centre, achieved with a $\mathrm{P}, \mathrm{N}$-bidentate ligand such as di(1-adamantyl)-2-morpholinophenylphosphine (Mor- 
DalPhos) (Scheme 3.4). ${ }^{58,59}$ This allowed weakly nucleophilic carboxamides, carboxylic acids and mesylates to react with it, forming oxazoles, esters and $\alpha$-mesyloxy ketones, respectively..$^{58,59}$
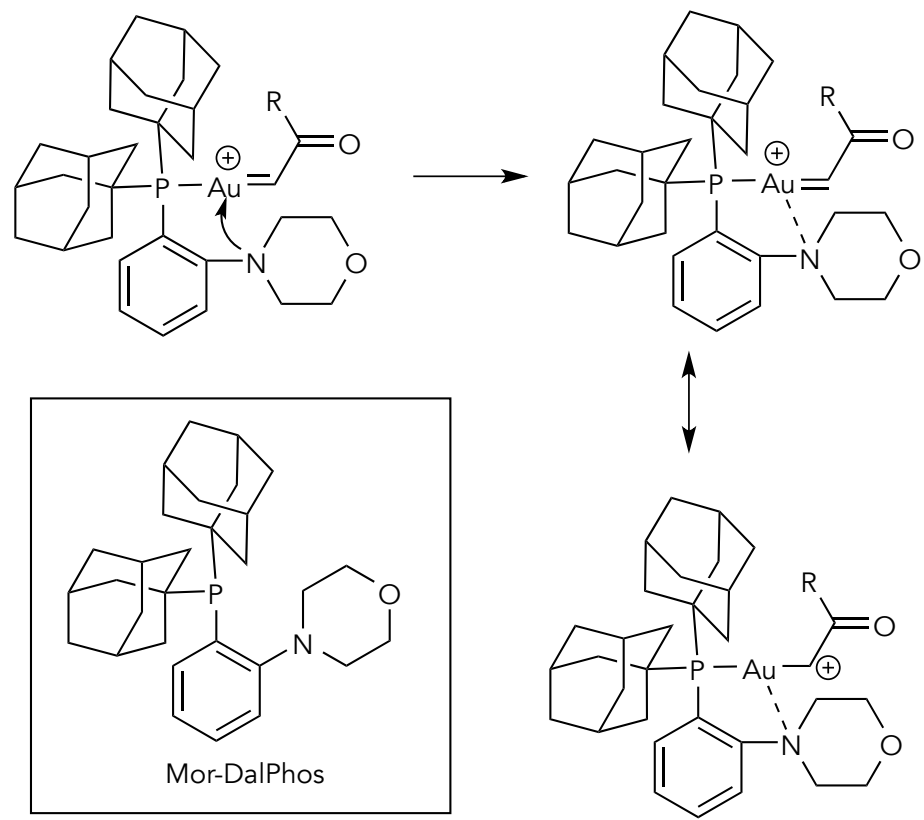

Scheme 3.4 Proposed role of Mor-DalPhos in stabilising the $\alpha$-oxo gold carbene, as represented by Zhang. ${ }^{59}$

Using the gold catalyst Mor-DalPhosAuOMs, Zhang and colleagues synthesised a range of $\alpha$ mesyloxy ketones through the reaction of terminal alkynes with methanesulfonic acid. As mesylate is a good leaving group, it facilitated substitution by a thioamide in situ to afford 2,4disubstituted thiazoles. ${ }^{58}$ The proposed reaction mechanism (Scheme 3.5) involves the oxidation of the terminal alkyne by 8 -methylquinoline $N$-oxide to form an $\alpha$-oxo gold carbene. The electrophilic gold carbene intermediate then reacts with mesylate to form an $\alpha$-mesyloxy ketone ${ }^{60}$ which can then be replaced in situ with a thioamide to form a thiazole. ${ }^{58}$ 

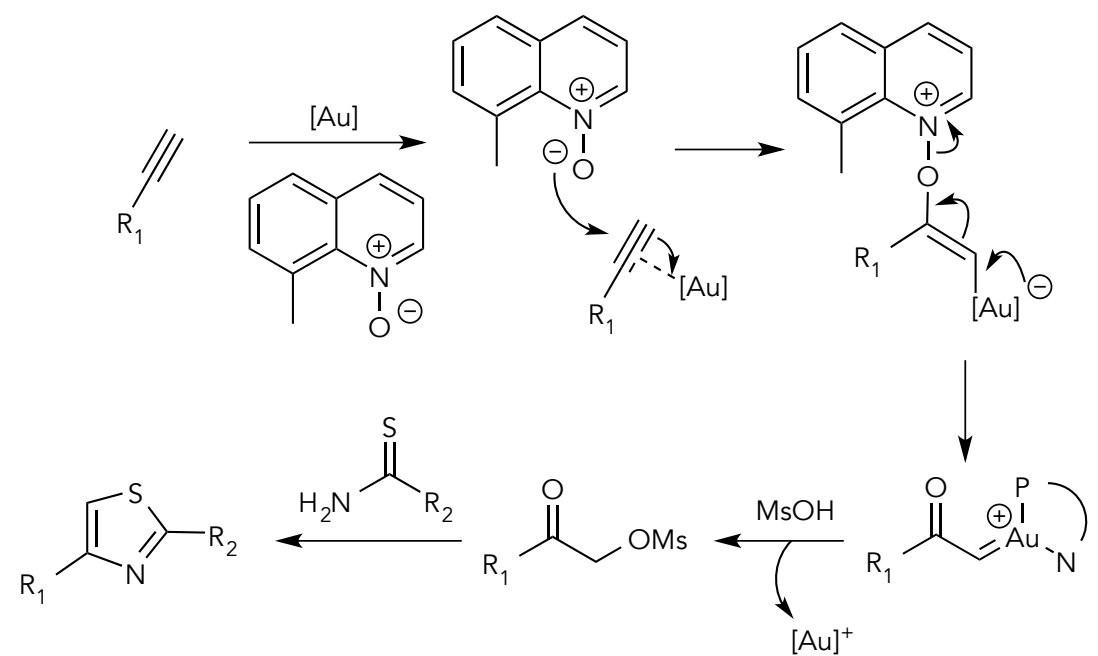

Scheme 3.5 Proposed mechanism of gold-catalysed thiazole synthesis (modified from Xiang and Zhang)..$^{58,60}$

\subsubsection{Model Thiazole Formation Reactions}

Before synthesising thiazole 136, a series of model thiazole formation reactions were undertaken to investigate and optimise the methods from Zhang and colleagues. It was far more cost effective to oxidise 8-methylquinoline 139 using 1.3 equivalents of metachloroperbenzoic acid (mCPBA) following conditions by Antonchick and Bering (Scheme 3.6), ${ }^{61}$ than purchasing the commercially available 8-methylquinoline $\mathrm{N}$-oxide 140 required for the thiazole synthesis. ${ }^{*}$

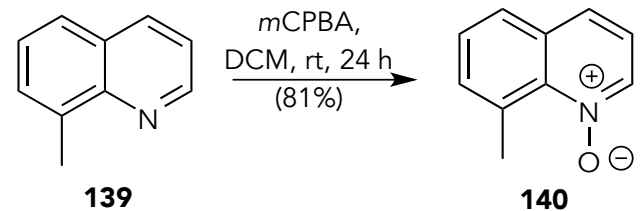

Scheme 3.6 Synthesis of 8-methylquinoline N-oxide 140.

Zhang and colleagues synthesised Mor-DalPhosAuOMs from the treatment of commercially available Mor-DalPhosAuCl with silver mesylate, ${ }^{58}$ however, the commercially available MorDalPhosAuNTf 2 was used for this project, as formation of an $\alpha$-mesyloxy ketone is only an intermediate towards the synthesis of a thiazole, the mesylate counter ion was not necessary.

${ }^{*}$ (NZD) $\$ 387.50$ for $5 \mathrm{~g}$ of 8-methylquinoline $\mathrm{N}$-oxide, $\$ 67.50$ for $5 \mathrm{~g}$ of 8 -methylquinoline, $\$ 84.30$ for $25 \mathrm{~g}$ of $\mathrm{mCPBA}$. Prices taken from Sigma-Aldrich online on the $6^{\text {th }}$ March 2016. 
The first model reaction was performed using 6-heptanoic acid (97) and a model thioamide, propanethioamide 142, which was synthesised from propanamide by treatment with Lawesson's reagent. Unfortunately thiazole formation was not observed; instead, 6oxoheptanoic acid (71) was formed (Scheme 3.7), as determined by ${ }^{1} \mathrm{H}$ and ${ }^{13} \mathrm{C}$ NMR spectroscopy. It was hypothesised that the formation of 71 was a result of introduction of water into the reaction, which could disrupt the $\alpha$-oxo gold carbene formation; thus, all subsequent thiazole reactions were conducted under argon and used reagents dried under high vacuum. Zhang and colleagues had shown that carboxylic acids can react with the $\alpha$-oxo gold carbene to produce esters, ${ }^{58}$ and while this was not observed with the reaction with propanethioamide 142, a different model alkyne was used in subsequent reactions.

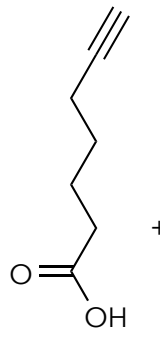

97<smiles>CCC(N)=S</smiles>

142

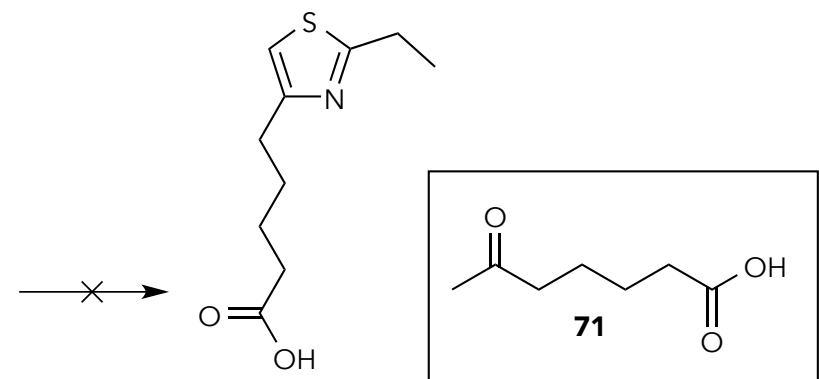

Scheme 3.7 Attempted thiazole formation with 97 and 142, leading to the formation of 71 .

Successful thiazole formation was later achieved using phenylacetylene 141 and propanethioamide 142 (Scheme 3.8), to give thiazole 143 in a 12\% yield. A reason for the low yield may be the use of a different gold catalyst compared to Zhang and colleagues, or the quality of methanesulfonic acid used, as it was difficult to purify; nevertheless, this model reaction showed that thiazole formation can be achieved, although further optimisation is required.

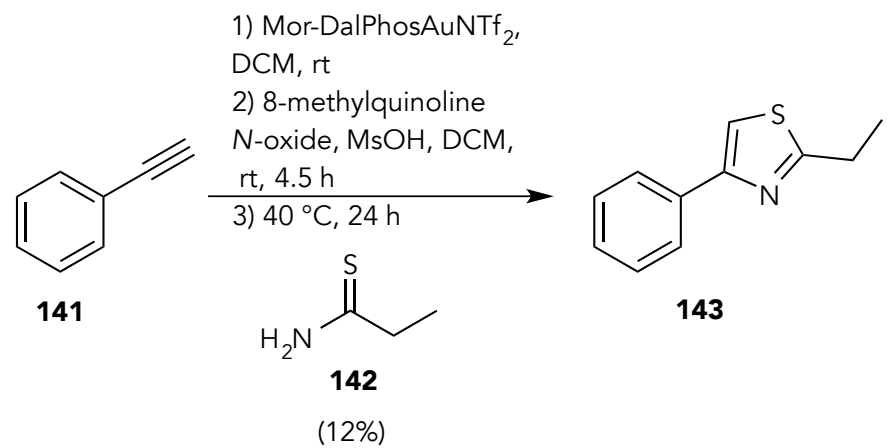

Scheme 3.8 Model reaction for thiazole formation methodology. 


\subsubsection{Thiazole Formation and Completion of the Synthesis of Analogue}

130

To avoid inadvertent reaction of the acid functionality of 6-heptanoic acid (97) with the $\alpha$-oxo gold carbene, the lactone 98 was attached via a modified Steglich esterification (Scheme 3.9) using conditions developed by Cumming. ${ }^{15}$

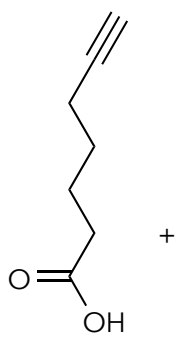

97

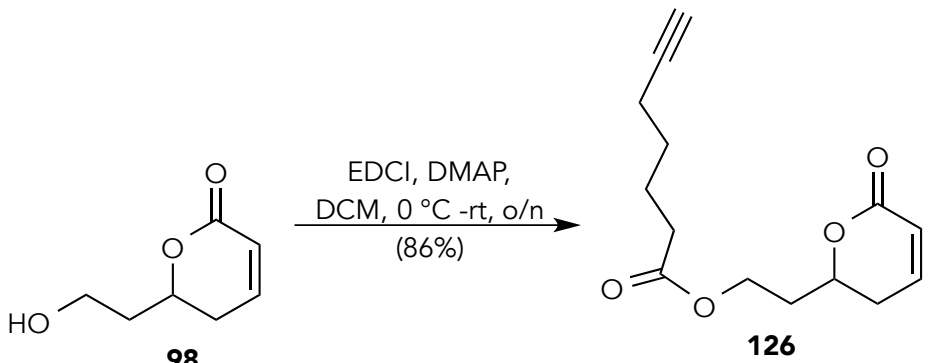

98
126

After the successful, though low yielding, synthesis of thiazole 143, the synthesis of thiazole 136 was undertaken (Scheme 3.10). As methanesulfonic acid was difficult to purify, handle and transfer, para-toluenesulfonic acid (pTSA), which was recrystallised from $\mathrm{Et}_{2} \mathrm{O}$ and petroleum ether and dried, was used instead. The choice of using PTSA instead of methanesulfonic acid is supported by the precedence in literature for the formation of thiazoles via $\alpha$-tosyloxy ketones. ${ }^{62,63,64}$ Thankfully, this strategy gave thiazole 136 in an overall yield of $44 \%$ in two steps from 6-heptanoic acid (97), which provided a thiazole in a higher yield than the $30 \%$ for the preparation of $\alpha$-bromoketone and Hantzsch thiazole formation for the DMDA analogue 68 by Romo. $^{14}$

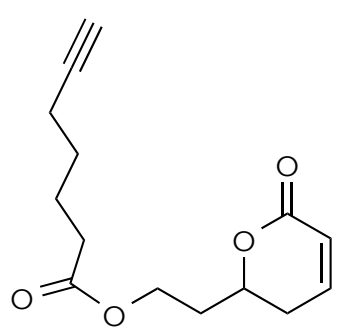

126

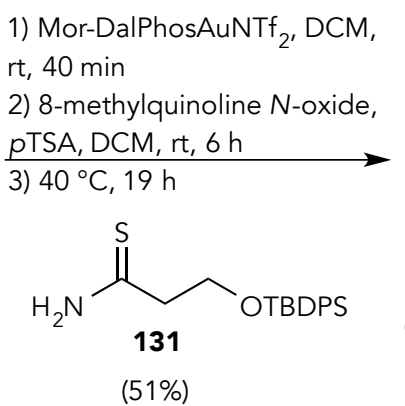

(51\%)

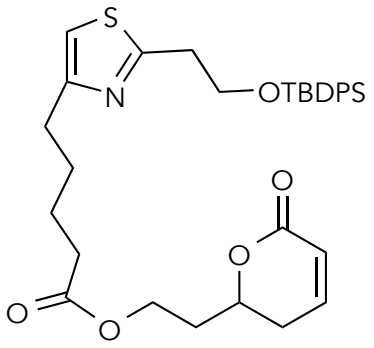

136

Scheme 3.10 Synthesis of thiazole 136 .

Simultaneous desilylation and eliminative lactone opening of 136 was achieved with seven equivalents of TBAF to give seco acid 137 (Scheme 3.11). Attempts to lower the excess of 
TBAF used in this reaction led to successful deprotection of the silyl protecting group; however, incomplete conversion of the $\delta$-lactone to the Z,E-dienoate moiety was observed.<smiles>CCCCO[OH+]CCc1nc(CCCCC(=O)OCCC2CC=CC(=O)O2)cs1</smiles>

136
TBAF, THF,

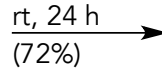

$(72 \%)$

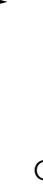<smiles>O=C(O)/C=C\C=C\CCOC(=O)CCCCc1csc(CCO)n1</smiles>

137
1) $\mathrm{TCBC}, \mathrm{NEt}_{3}$,

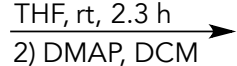
$-78^{\circ} \mathrm{C}-\mathrm{rt}, 24 \mathrm{~h}$ $(14 \%)$<smiles>O=C1/C=C\C=C/CCOC(=O)CCCCc2csc(n2)CCO1</smiles>

130

Scheme 3.11 Completion of the synthesis of analogue 130 .

Finally, macrolactonisation of seco acid 137 was achieved using the modified Yamaguchi conditions developed by Cumming for the synthesis of $96,{ }^{15}$ giving the analogue 130 in a $14 \%$ yield. Similarly low yields were also observed by Cumming, who hypothesised that the low yields were a result of a low reaction temperature and the use of catalytic amounts of DMAP leading to incomplete conversion of starting material, rather than the isomerisation of the Z,Edienoate system. ${ }^{15}$ However, on close examination of the ${ }^{1} \mathrm{H}$ NMR spectrum of the crude material from the Yamaguchi reaction of 137, evidence of a possible geometric isomer can be seen (Figure 3.5). Compared to the alkene shifts for the Z,E-dienoate system of analogue 130 (blue in Figure 3.5), the possible E,E-dienoate system has shifted substantially (red in Figure 3.5). This is consistent with observations by Cumming who synthesised both a $Z, E-$ and $E, E-$ dienoate macrocycle. ${ }^{15}$ 


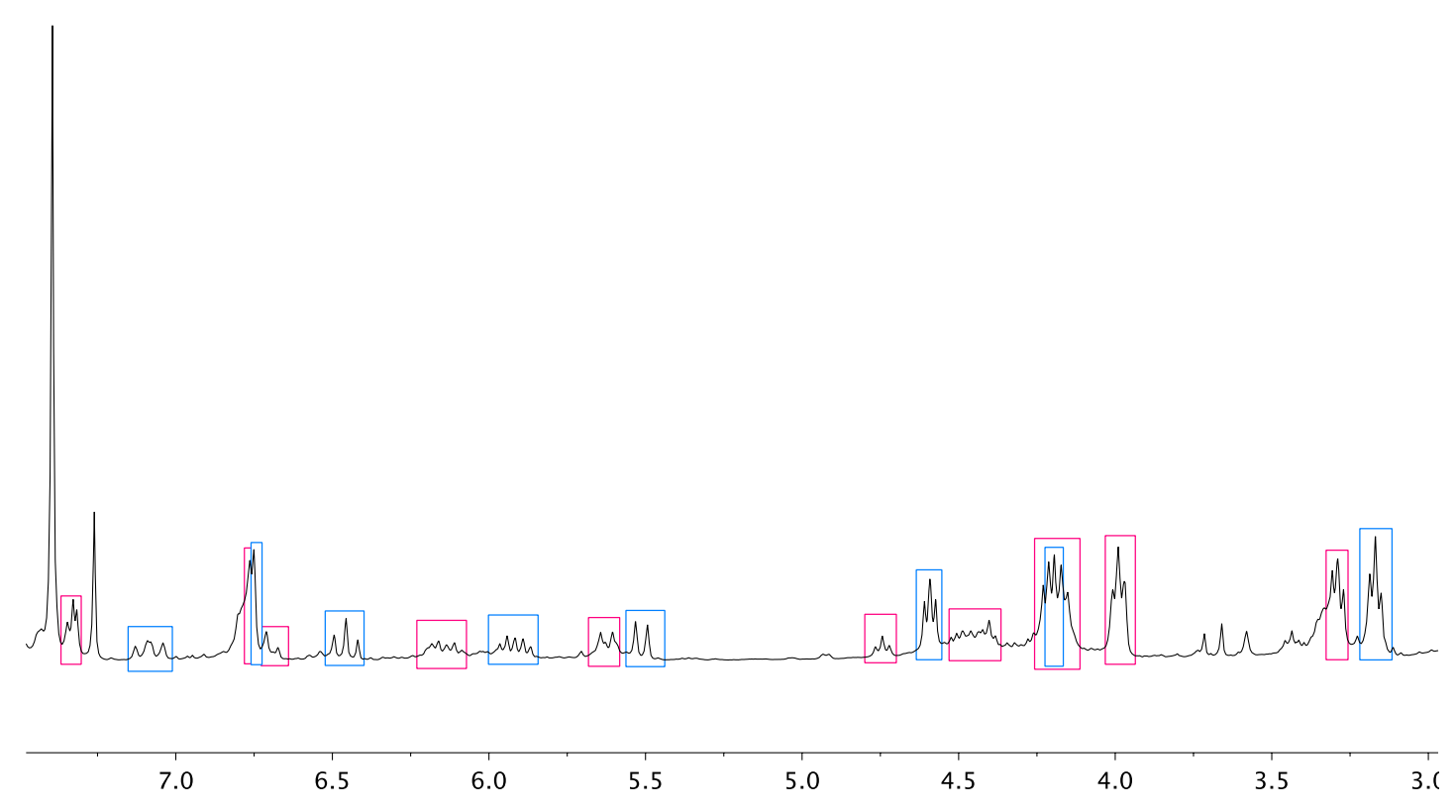

Figure $3.5{ }^{1} \mathrm{H}$ NMR spectrum $\left(500 \mathrm{MHz}_{1} \mathrm{CDCl}_{3}\right)$ of crude material from the Yamaguchi reaction, showing potential E,E-dienoate-containing by-products (red) with desired Z,E-dienoate-containing macrocycle 130

(blue).

While analogue 130 and the geometric isomer were indistinguishable from each other on TLC, separation of the Z,E-dienoate macrocycle 130 using gradient silica gel column chromatography starting at 10:1 n-hexane: ethyl acetate, and eluting at 6:1 n-hexane: ethyl acetate successfully provided 130 in sufficient amounts for chemical analysis and biological testing. As the Yamaguchi macrolactonisation provided analogue 130 in low yields with some potential isomerism of the Z,E-dienoate system, it will be advantageous to change to an alternative macrolactonisation reaction. As the acid functionality of 137 is conjugated to the Z,E-dienoate, activation of the alcohol functionality of 137 through a Mitsunobu macrolactonisation may avoid isomerisation of this delicate Z,E-dienoate system, and should be investigated in the future.

\subsubsection{Summary}

Two major fragments, lactone 98 and thioamide 131, were prepared for the synthesis of analogue 130. An efficient method for thiazole formation was developed using modifications of the conditions by Zhang and colleagues, ${ }^{58}$ which gave model thiazole 143 from phenylacetylene (141) and propanethioamide 142 in 12\%. After developing successful thiazole formation methodology alkyne 126, which was synthesised from 6-heptanoic acid (97) 
and lactone 98 via a modified Steglich esterification, was treated with thioamide 131 and the gold catalyst Mor-DalPhosAuNTf 2 to give thiazole 136 in 51\% yield based on recovered starting material. The higher yield compared to thiazole 143 could have been due to the change from methanesulfonic acid to pTSA, which was easier to purify, handle and transfer. Treatment of thiazole 136 with TBAF promoted simultaneous desilylation and eliminative lactone opening to provide seco acid 137, which was then subjected to a Yamaguchi macrolactonisation to afford analogue 130 in an overall yield of $0.8 \%$ in 11 steps based on the longest linear sequence. As expected from the synthesis of $96,{ }^{15}$ the macrolactonisation step was low yielding, as some potential isomerism of the Z,E-dienoate system occurred; however, sufficient amounts of analogue 130 were isolated in pure form to continue with biological testing.

\subsection{Towards the Synthesis of a Side Chain-containing Analogue of} 130

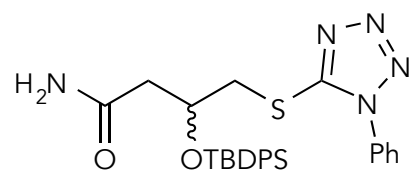

148

Figure 3.6 Synthesis of amide 148 towards the synthesis of a side chain-containing analogue of 130 .

With successful thiazole methodology developed, synthesis of a side chain-containing analogue of 130 can be undertaken. Following the precedence from the synthesis of 96 by Cumming ${ }^{15}$ it was anticipated that the side chain would be linked to the macrocycle via a JuliaKocienski olefination; thus the heteroatom-containing fragment must contain a phenyltetrazolylsulfone moiety. To investigate the methodology required for the extension to a side chain-containing analogue of 130 , amide 148 was synthesised (Figure 3.6).

\subsubsection{Synthesis of Amide 148}

Inspired by work of Fleming and co-workers, ${ }^{65}$ the epoxidation of 3-butenenitrile (144) was achieved by adding mCPBA portion-wise over a total of seven days at room temperature (Scheme 3.12). This led to a mixture of epoxide 145 and starting material 144; however, it was more expedient to purify the reaction mixture after treatment with mercaptophenyltetrazole 
113, which gave alcohol 146 in $31 \%$ yield over two steps. Cumming achieved quantitative yields for the ring opening of epichlorohydrin (112) with mercaptophenyltetrazole 113, perhaps as a result of using 100-times excess of epichlorohydrin 112 compared to $113,{ }^{15}$ whereas epoxide 145 was the limiting reagent in the synthesis of alcohol 146.

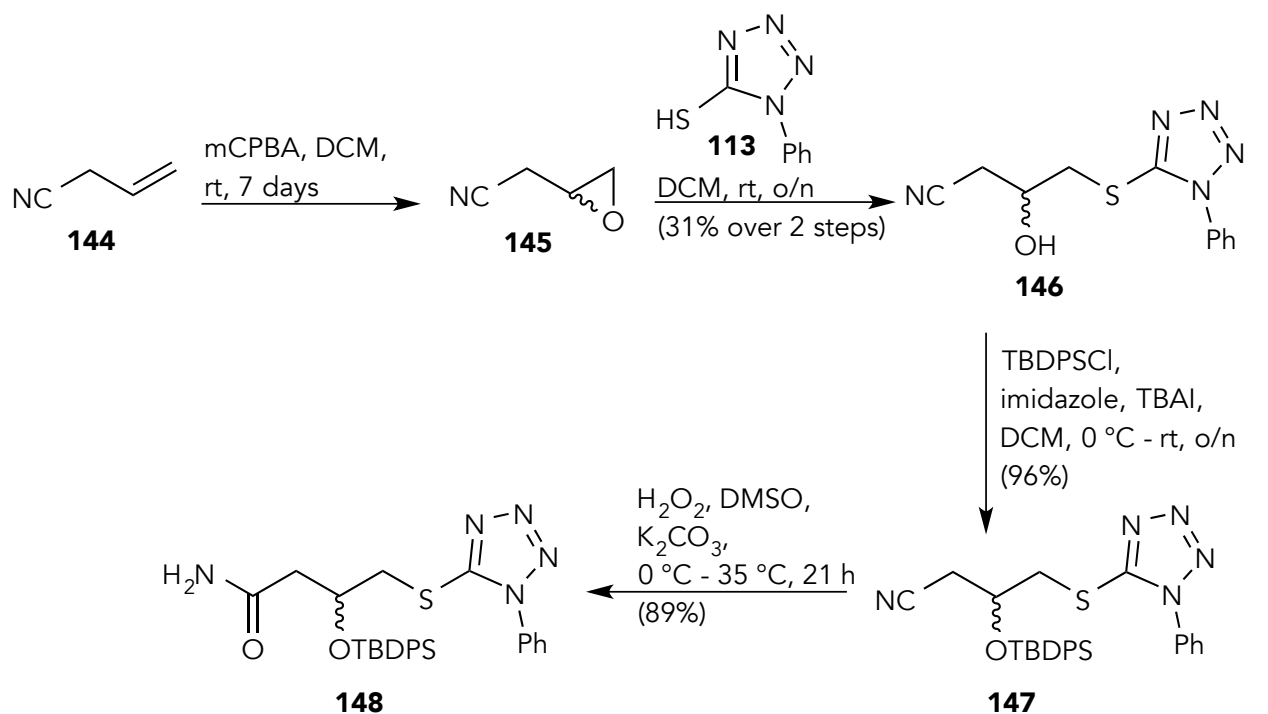

Scheme 3.12 Synthesis of amide 148 towards the synthesis of a side chain-containing analogue.

Compared to the TBDPS protection of 3-hydroxypropionitrile (132) for the synthesis of the thioamide fragment 131 (see Section 3.1.2), protection of alcohol 146 was problematic. Different conditions were tested (Table 3.1); however, these tended to be low yielding or had very long reaction times. Conducting the reaction at higher temperatures led to a decreased yield, as seen in entry 6 compared to entry 5 , which showed that the reaction is temperature sensitive. Fortunately, increasing the excess of TBDPSCI used led to higher yields; hence, the final conditions (entry 7) used three equivalents of TBDPSCl to give 147 in $96 \%$ yield. 


\begin{tabular}{|c|c|c|c|c|c|}
\hline Entry & Reagent & Solvent & Temperature & $\begin{array}{l}\text { Reaction } \\
\text { time }\end{array}$ & Yield of 147 \\
\hline 1 & $\begin{array}{l}\text { TBDPSCI (1.1 eq.), } \\
\text { imidazole }\end{array}$ & DMF & $0{ }^{\circ} \mathrm{C}-\mathrm{rt}$ & Overnight & $\begin{array}{l}1-13 \%(7-63 \% \text { based } \\
\text { on recovered SM) }\end{array}$ \\
\hline 2 & $\begin{array}{l}\text { TBDPSCl (1.5 eq.), } \mathrm{NEt}_{3}, \\
\text { DMAP }\end{array}$ & DCM & $0{ }^{\circ} \mathrm{C}-\mathrm{rt}$ & 2 days & $5 \%$ \\
\hline 3 & $\begin{array}{l}\text { TBDPSCl (1.5 eq.), } \\
\text { imidazole, } \mathrm{AgNO}_{3}\end{array}$ & THF & $0{ }^{\circ} \mathrm{C}-\mathrm{rt}$ & 2 days & No observed product \\
\hline 4 & $\begin{array}{l}\text { TBDPSCl }(1.5 \text { eq), } \\
\text { imidazole, TBAI }\end{array}$ & DMF & $0^{\circ} \mathrm{C}-r \mathrm{t}$ & 2 days & $5 \%$ \\
\hline 5 & $\begin{array}{l}\text { TBDPSCI (2.2. eq.), } \\
\text { imidazole, DMAP }\end{array}$ & DMF & $0^{\circ} \mathrm{C}-\mathrm{rt}$ & 9 days & $72 \%$ \\
\hline 6 & $\begin{array}{l}\text { TBDPSCl (2.2 eq.), } \\
\text { imidazole, DMAP }\end{array}$ & DMF & $0-40^{\circ} \mathrm{C}$ & 9 days & $\begin{array}{l}5 \%(12 \% \text { based on } \\
\text { recovered } \mathrm{SM})\end{array}$ \\
\hline 7 & $\begin{array}{l}\text { TBDPSCl (3 eq.), } \\
\text { imidazole, TBAI }\end{array}$ & $\mathrm{DCM}$ & $0^{\circ} \mathrm{C}-\mathrm{rt}$ & Overnight & $96 \%$ \\
\hline
\end{tabular}

Table 3.1 Reaction conditions for protection of alcohol 146 with TBDPS.

$\mathrm{Eq}=$ equivalence.

Initially, the conversion of nitrile 147 to amide 148 was unsuccessful using the same conditions from Katritzky and co-workers ${ }^{50}$ that was used for the synthesis of amide 131 (see Scheme 3.2), which was hypothesised to be due to the steric constraints imposed on the nitrile of 147 by the phenyltetrazolylsulfone moiety, compared to the unsubstituted nitrile 134 . Reactions performed at room temperature at a range of reaction times afforded amide 148 in low yields, with some starting material and TBDPSOH recovered (Entry 1-3, Table 3.2). It is hypothesised that any substantially polar by-products, such as deprotected starting material or product, would have been lost in the aqueous workup. Finally, use of warmer reaction temperatures, and a reaction time of 21 hours on a larger scale $(500 \mathrm{mg})$ gave the desired amide 148 in a pleasing 89\% yield (Entry 5, Table 3.2). 


\begin{tabular}{|l|l|l|l|}
\hline Entry & Temperature & Reaction Time & Yield of 148 \\
\hline 1 & $0{ }^{\circ} \mathrm{C}-\mathrm{rt}$ & 2.5 hours & $5 \%$ \\
3 & $0{ }^{\circ} \mathrm{C}-\mathrm{rt}$ & 17.5 hours & $10 \%$ \\
4 & $0{ }^{\circ} \mathrm{C}-\mathrm{rt}$ & 3 days & $27 \%$ \\
$5 *$ & $0-35^{\circ} \mathrm{C}$ & 18 hours & $22 \%$ \\
\hline & $0-35{ }^{\circ} \mathrm{C}$ & 21 hours & $89 \%$ \\
\hline \multicolumn{4}{|c|}{ Table 3.2 Reaction conditions for the hydrolysis of nitrile 147 to } \\
\end{tabular}

\subsubsection{Summary}

In addition to analogue 130, synthesis of racemic amide 148 has also been achieved with an overall yield of $26 \%$ over four steps from commercially available 3-butenenitrile (144). The synthesis of amide 148 was undertaken to develop the methodology for extending the side chain fragment to the thiazole-containing macrocycle via a Julia-Kocienski olefination, as seen for the synthesis of 96 by Cumming..$^{15}$ Good yields were achieved for the TBDPS protection of alcohol 146 to 147 and conversion of nitrile 147 to amide 148 ( $96 \%$ and $89 \%$, respectively); however, the two-step synthesis of phenyltetrazolylsulfone-containing alcohol 146 via the epoxidation of 3-butenenitrile (144) was low yielding (31\% over two steps). Increasing the excess of either intermediate epoxide 145 or mercaptophenyltetrazole 113 may give higher yields, and should be investigated in future work.

\subsection{Biological Activity of Analogue 130}

The biological activity of analogue 130 was investigated in 1A9 (human ovarian carcinoma) cells using an MTT (3-(4,5-dimethylthiazol-2-yl)-2,5-diphenyltetrazolium bromide) assay, which determines the number of metabolically active cells after treatment with a drug, through the reduction of the yellow tetrazolium dye into purple formazan precipitates by NADH/NADPH produced by the cells. ${ }^{66}$ After treatment of the cells with MTT, the insoluble purple formazan precipitates were then solubilised, and the effect of various concentrations of the drug on the cells was quantified spectrophotometrically at $570 \mathrm{~nm}$. 


\subsubsection{Cell Proliferation Assay of Analogue 130}

It was hypothesised that analogue 130 would not inhibit cell growth, as it is devoid of the side chain that is part of the proposed binding domain of pateamine,${ }^{14}$ and that has been shown by Romo and colleagues as essential for biological activity ${ }_{i}{ }^{2}$ however, determination of the half maximal inhibitory concentration $\left(\mathrm{IC}_{50}\right)$ was investigated regardless. As the potency of analogue 130 was unknown, a wide concentration range was used, starting from $1 \mathrm{mM}$ followed by a 2fold serial dilution to $2 \mu \mathrm{M}$ (Figure 3.7). From this, the $\mathrm{IC}_{50}$ was determined as $460 \pm 63.7 \mu \mathrm{M}$, which is substantially higher than the $\mathrm{IC}_{50}$ of $51.1 \mu \mathrm{M}$ for the triazole-containing analogue 96 in 1A9 cells. This result supports the hypothesis that analogue 130 would not have a high biological activity (low $\mu \mathrm{M}$ ), as it is devoid of the side chain of pateamine, and furthers the need to synthesise a side chain-containing analogue of 130 .

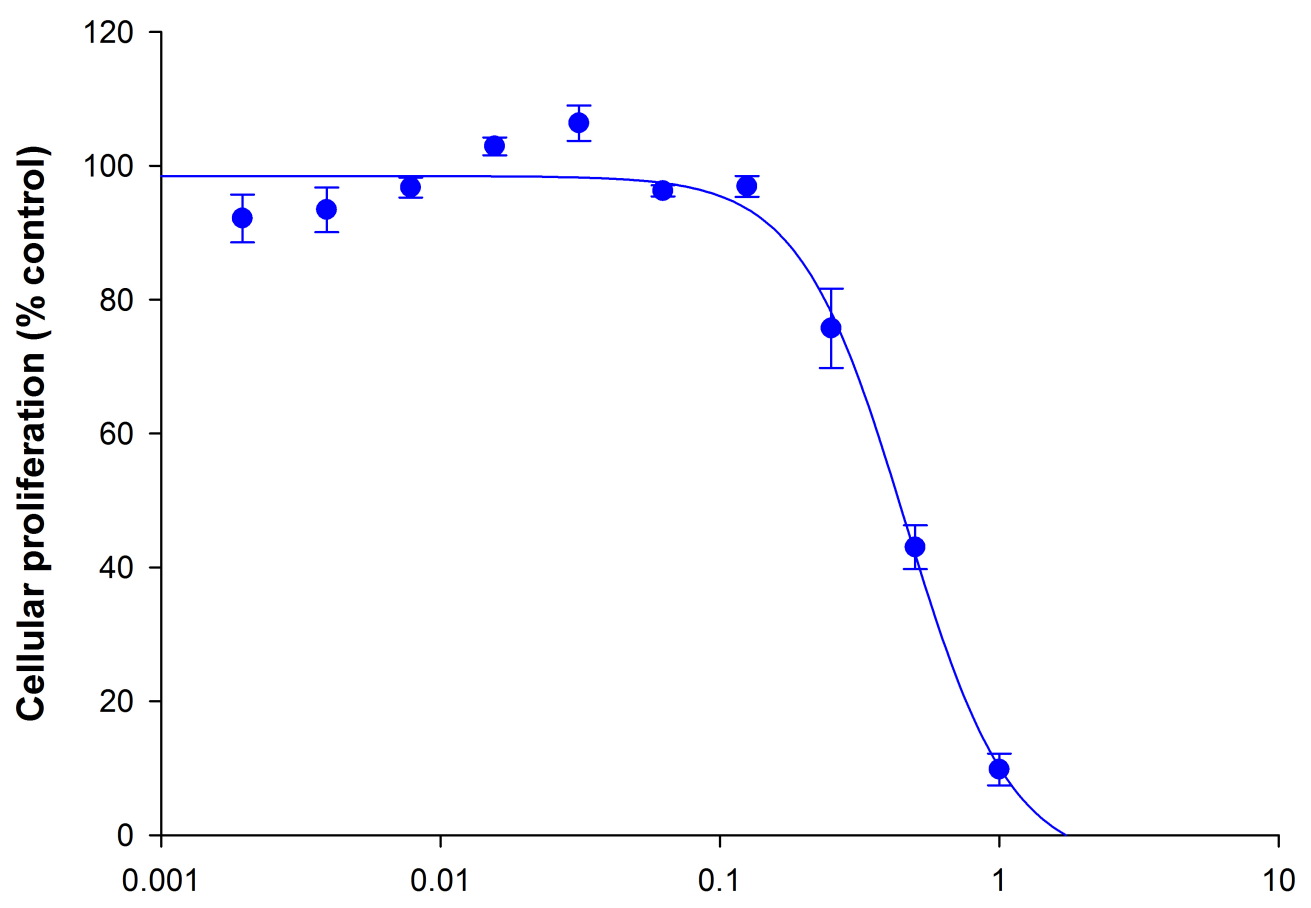

Concentration of analogue $130(\mathrm{mM})$

Figure 3.7 MTT assay results of 1 A9 cells treated with analogue $130, n=3$. 


\subsubsection{Competitive Bioactivity Assay Between Analogue 130 and}

Pateamine

To determine if analogue 130 binds to the biological target of pateamine, elF4A, a competitive bioactivity assay was undertaken. It was hypothesised that if analogue 130 bound to elF4A and was not displaced by pateamine, that cell growth would not be inhibited when treated with pateamine. Half of the cells were treated with analogue $130(0.25 \mathrm{mM})$ followed by an incubation time of 12 hours, after which all of the cells were treated with a 2 -fold serial dilution of pateamine starting at a concentration of $50 \mathrm{nM}$. The $\mathrm{IC}_{50}$ value of pateamine was determined after 58 hours of treatment as $1.11 \pm 2.37 \mathrm{nM}$, and the $\mathrm{IC}_{50}$ value of pateamine in cells treated with analogue 130 as $1.57 \pm 0.17 \mathrm{nM}$ (Figure 3.8). The survival curves obtained are more consistent with additive, rather than competitive action of pateamine and analogue 130. As the $\mathrm{IC}_{50}$ values of both treatments were similar, this suggests that analogue 130 either does not bind to elF4A, or that it binds non-covalently to elF4A and is then displaced by pateamine.

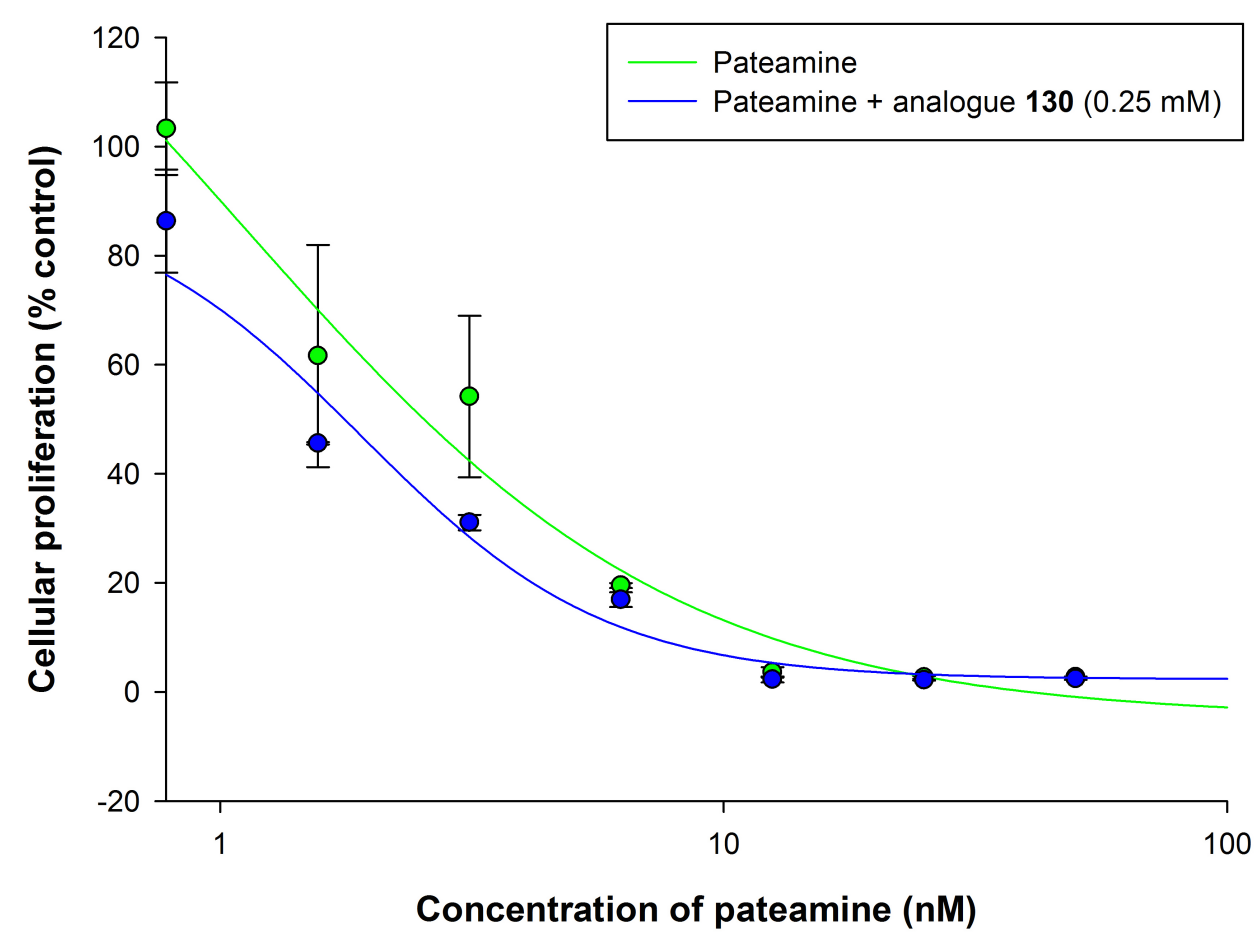

Figure 3.8 MTT competitive binding assay results of $1 \mathrm{~A} 9$ cells treated with either pateamine or pateamine + analogue 130 after 58 hours, $\mathrm{n}=2$. 
While there has been no reported $I C_{50}$ value of pateamine in $1 \mathrm{~A} 9$ cells, the results obtained in this project are consistent with the $\mathrm{IC}_{50}$ values between 1.4-2.0 $\mathrm{nM}$ shown in MTT assays with HL-60, HeLa and SH-SY5Y cell lines after 24 hours of treatment with pateamine. ${ }^{21}$ 


\section{CHAPTER FOUR: CONCLUSION AND FUTURE WORK}

\subsection{Conclusion}

The natural product pateamine (1, Figure 4.1) is a potent anticancer lead, ${ }^{1}$ and has therapeutic potential for treatment of Alzheimer's disease, ${ }^{37}$ prevention of cachexia, ${ }^{30}$ and inhibition of influenza $A,{ }^{45}$ which is due to its ability to inhibit the eukaryotic initiation factor elF4A. ${ }^{23,24}$ Pateamine is found in its natural environment in such small amounts that it is necessary to synthesise pateamine and pateamine analogues to further investigate its therapeutic potential. A simplified DMDA pateamine analogue 68 was synthesised by Romo and colleagues, as a means of investigating the proposed binding and scaffolding domain of pateamine. ${ }^{14}$ Analogue 68 was synthesised in an overall yield of $7 \%$ in 14 steps, $^{14}$ which was a great improvement compared to the overall yields of pateamine achieved by Romo's and Pattenden's groups of $0.2 \%$ in over 20 steps. ${ }^{11,13}$ This simplification of pateamine did not lead to a reduction in biological activity, ${ }^{14,2}$ which led to further investigation of other simplified pateamine analogues. In 2014 Cumming synthesised a simplified triazole-containing pateamine analogue 96 , to determine if the thiazole functionality was necessary to retain biological activity. As this analogue had substantially reduced biological activity compared to pateamine and the DMDA analogue 68 , it was necessary to determine if the reduction of biological activity was due to the replacement of the thiazole with a triazole, or due to the removal of the methyl groups. 
<smiles>C/C=C\C=C/C(=O)O[C@H](/C=C(C)/C=C/C(C)=C/CN(C)C)Cc1nc([C@@H](C)C[C@H](N)CC(=O)O[C@H](C)C[C@@H](C)N)cs1</smiles>

Pateamine, 1<smiles>CC=CC=CC(=O)OC(C=C(C)C=CC(C)=CCNC)Cc1nc(CCCCC(=O)OC(C)C)cs1</smiles>

68<smiles>CNC/C=C/C=C/C=C/[C@H](Cn1cc(CCCCC(=O)OCC/C=C/C=C\C(=O)O)nn1)OC</smiles>

96

Figure 4.1 Pateamine 1, DMDA pateamine analogue 68, and triazole-containing analogue 96.

The aim of this Master's project was to synthesise a highly simplified side chain-free thiazolecontaining analogue 130 (Figure 4.2), and investigate its biological activity. During the synthesis of 130, particular attention was paid to the development of an efficient thiazole formation methodology and investigation into the low yielding Yamaguchi macrolactonisation reaction seen for the synthesis of analogue 96. This would therefore lay the groundwork for a subsequent synthesis of a thiazole-containing analogue of 96 .

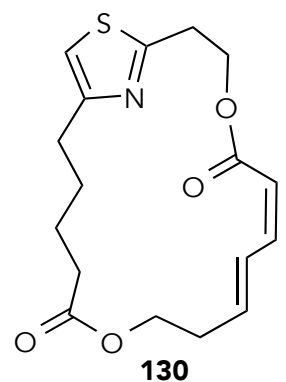

Figure 4.2 Analogue 130 that was synthesised for this project.

The synthesis of 130 started with the preparation of two major fragments, lactone 98 and thioamide 131 (Figure 4.3). The synthesis of lactone 98 mostly followed Cumming's methodology and gave 98 in an overall 16\% yield in seven steps. The novel thioamide 131 was synthesised from 3-hydroxypropionitrile (132), starting with TBDPS-protection of the 
hydroxyl functionality, followed by hydrolysis of the nitrile to an amide using basic conditions, and then treatment with Lawesson's reagent to give thioamide 131 in an overall $43 \%$ yield.

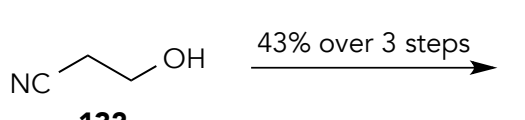

132

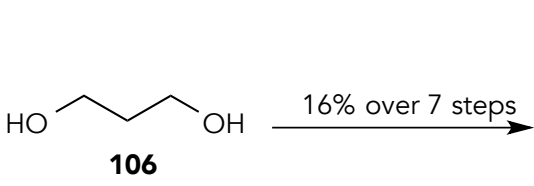

Figure 4.3 Synthesis of two major fragments 98 and 131.

With these fragments in hand completion of analogue 130 proceeded, starting with the coupling of commercially available 6-heptanoic acid (97) and lactone 98 to give 126 (Figure 4.4). An efficient thiazole formation methodology using conditions modified from those of Zhang and colleagues ${ }^{58}$ was developed and tested on a model terminal alkyne, phenylacetylene 141, and thioamide, propanethioamide 142, which gave thiazole 143 in a $12 \%$ yield (see Scheme 3.8). After the successful thiazole formation, albeit low yielding, the methodology was applied to the reaction of 126 with thioamide 131, which afforded thiazole 136 in a $51 \%$ yield. A reason for the higher yield compared to thiazole 143 may have been due to the change from the difficult to handle and purify methanesulfonic acid to pTSA. Treatment of thiazole 136 with TBAF promoted simultaneous desilylation and lactone opening to afford seco acid 137, and finally macrolactonisation of 137 gave the analogue 130 in an overall $0.8 \%$ yield over 11 steps based on the longest linear sequence. Some geometric isomerism of the Z,E-dienoate system of analogue 130 was observed in the crude material following the Yamaguchi reaction, which would account for the low yield of the reaction, and thus future work should explore alternative macrolactonisation approaches. 


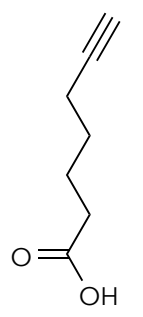

97<smiles>C=CCCCC(=O)OCCC1CC=CC(=O)O1</smiles>

126

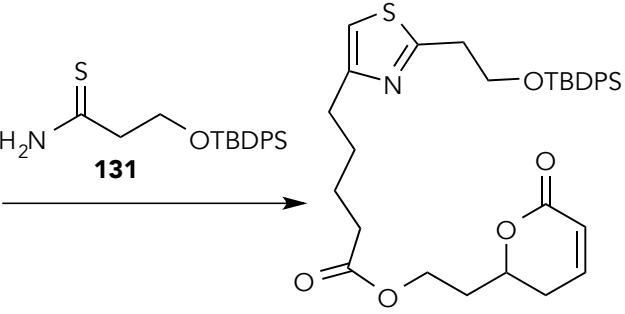<smiles>O=C1/C=C\C=C\CCOC(=O)CCCCc2csc(n2)CCO1</smiles>

130
136<smiles>O=C(O)/C=C\C=C/CCOC(=O)CCCCc1csc(CCO)n1</smiles>

137

Figure 4.4 Coupling of fragments 97,98 and 131 in completion of the synthesis of analogue 130 .

The biological activity of analogue 130 was then investigated on 1A9 cancer cells using a MTT assay, which showed that analogue 130 had an IC 50 value of $460 \mu \mathrm{M}$. This $I C_{50}$ value is substantially higher than the triazole-containing analogue $96(51.1 \mu \mathrm{M}) i^{15}$ however, it was hypothesised that analogue 130 would not inhibit cell growth, as it is devoid of the side chain moiety that has been shown to be necessary for biological activity. ${ }^{2}$ The binding of analogue 130 to the biological target of pateamine, elF4A, was also investigated indirectly through a competitive bioactivity assay with pateamine. The results showed that even at a high concentration $(0.25 \mathrm{mM})$ either analogue 130 does not bind to elF4A, or that it binds noncovalently and is then displaced by pateamine.

The research presented here has laid the groundwork for the development of future simplified analogues of the potently bioactive natural product, pateamine. With potential therapeutic endpoints in the treatment of cancer, ${ }^{1,21}$ cachexia, ${ }^{30}$ viral infections, ${ }^{45}$ and Alzheimer's disease,${ }^{37}$ there is a great value for the synthesis of new analogues of pateamine that may have simplified synthetic approaches, and improved bioactivity. In making a highly simplified side chain-free pateamine analogue key synthetic challenges have been met, including the development of an efficient thiazole formation methodology. This work has also identified the reasons for the inefficiencies of the two steps that most significantly reduced the overall yield of analogue 130, allowing for future work to overcome these issues. These reaction were the Yamaguchi 
macrolactonisation, which was accompanied by isomerism of the Z,E-dienoate, and the thioamide formation, where the loss of the TBDPS-protecting group was observed.

\subsection{Future Work}

A racemic amide 148 (Figure 4.5) was synthesised from 3-butenenitrile (144) in this Master's project to investigate the methodology for attaching mercaptophenyltetrazole 113 to epoxide 145 in preparation for extension of the side chain via the Julia-Kocienski olefination; therefore, the next step will be to convert amide 148 to a thioamide using the Lawesson's reagent followed by oxidation of the thioether to provide the sulfone 149. As conversion of amide 135 to thioamide 131 was low yielding, with observation of recovered starting material and TBDPSOH, alternative reaction conditions, or protecting groups should be evaluated for the conversion of amide 148 to a thioamide.

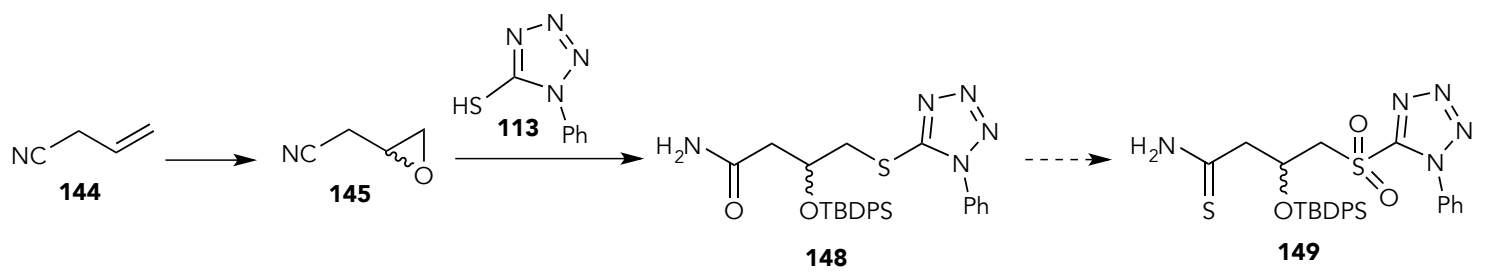

Figure 4.5 Tentative route towards the synthesis of the non-racemic thioamide 149 .

Once the racemic thioamide 149 has been synthesised, a non-racemic thioamide 150 can be developed (Figure 4.6), which could be achieved via a Shi or Jacobsen epoxidation of 3butenenitrile (144). With the methodology for the synthesis of alkyne 126 and side chain fragment 100 already developed, ${ }^{15}$ a side chain-containing analogue 151 could then be synthesised once thioamide 150 is formed. This will utilise the thiazole formation methodology developed in this project, as well as use a different macrolactonisation approach, to avoid isomerism of the Z,E-dienoate system that occurred during the synthesis of 130. A Mitsunobu macrolactonisation should be attempted, as the activation of the alcohol functionality of 137 , rather than the acid functionality, may avoid isomerism of the Z,E-dienoate system. 


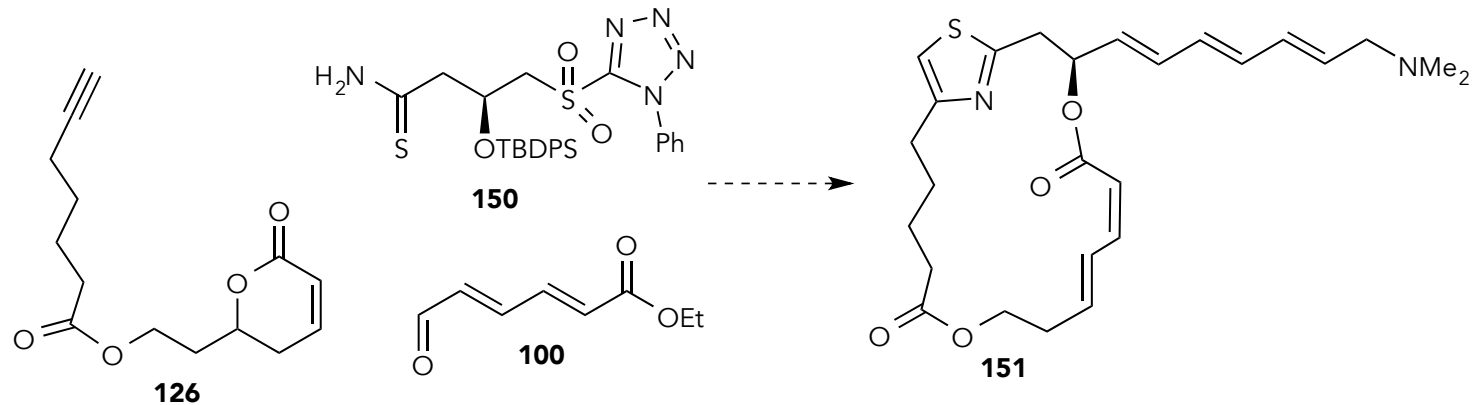

Figure 4.6 Tentative route to the side chain-containing analogue 151.

As side chain-containing analogue 151 bears all other structural characteristics of the triazolecontaining analogue 96, the biological activity of 151 using 1A9 and HL-60 cell lines can be compared to 96 to determine if the replacement to a triazole ring was responsible for the reduction in biological activity observed for 96 by Cumming. It is hypothesised that analogue 151 will show increased biological activity compared to the side chain-free analogue 130 synthesised in this project, and possibly an increased biological activity compared to analogue 96 as well. 


\section{CHAPTER FIVE: EXPERIMENTAL}

\subsection{General Experimental for Chemical Synthesis}

Unless otherwise stated, the following conditions apply. All reactions were performed under a nitrogen or argon atmosphere in oven-dried glassware. Dichloromethane (DCM), tetrahydrofuran (THF) and toluene used in reactions were taken from the solvent purification system (Innovative Technology PureSolv). Petroleum ether (PE), n-hexane, ethyl acetate (EtOAc), diethyl ether $\left(\mathrm{Et}_{2} \mathrm{O}\right), \mathrm{DCM}$ and methanol $(\mathrm{MeOH})$ were of $\mathrm{HPLC} /$ analytical reagent grade and used for column chromatography, extraction and filtration without further purification. Dimethylformamide (DMF) was stored over molecular sieves. Dimethyl sulfoxide (DMSO) and triethylamine $\left(\mathrm{NEt}_{3}\right)$ were distilled from $\mathrm{CaH}_{2}$. All other reagents and solvents were of commercial quality and used without further purification. Distilled water was used for all aqueous solutions (i.e. as the reaction solvent or the aqueous phase in workup). Organic solvents were removed via rotary evaporation with a water bath temperature between $35{ }^{\circ} \mathrm{C}$ and $40{ }^{\circ} \mathrm{C}$, and further dried under high vacuum. Reactions were monitored using polyesterbacked pre-coated silica TLC plates $\left(0.2 \mathrm{~mm}\right.$, with fluorescent indicator $U_{254}$, Macherey-Nagal) and visualised by UV irradiation (254 nm), in combination with $\mathrm{KMnO}_{4}$, anisaldehyde and iodine stains. Flash column chromatography was performed on silica gel $(60,40-63$ micron, Pure Science) using the indicated solvent system. ${ }^{1} \mathrm{H}$ NMR spectra were recorded on a Varian Unity Inova 500 Spectrometer operating at $500 \mathrm{MHz} .{ }^{13} \mathrm{C}$ NMR spectra were recorded on a Varian Unity Inova 500 Spectrometer operating at $125 \mathrm{MHz}$ with proton decoupling. NMR data are listed as follows: chemical shifts $(\delta)$ in ppm referenced against the residual or deuterated solvent peak ( ${ }^{1} \mathrm{H} \mathrm{NMR} \mathrm{CHCl}_{3}=7.26 \mathrm{ppm},{ }^{13} \mathrm{C} \mathrm{NMR} \mathrm{CDCl}_{3}=77.16 \mathrm{ppm}$ ), multiplicity (s = singlet, $d=$ doublet,$d d=$ doublet of doublets, $d t=$ doublet of triplets, $t=$ triplet, $t d=$ triplet of doublets, $\mathrm{q}=$ quartet, quin = quintet, $\mathrm{m}=$ multiplet, $\mathrm{bs}=$ broad singlet), integration and peak assignment. NMR peak assignments for novel compounds were made using COSY, HSQC and HMBC 2D experiments, and numbered according to the cyclic numbering system of the analogue 130, unless otherwise stated. Melting points were obtained using a Gallenkamp melting point apparatus. IR spectra were obtained with a Bruker Tensor 27 FTIR spectrometer equipped with an ATR sampling accessory. High-resolution mass spectrometry (HRMS) was performed on an Agilent Technologies 6530 Accurate Mass Q-TOF LC/MS instrument. 


\subsection{Experimental for Chemical Synthesis}

\subsubsection{Synthesis of Lactone Fragment 98}

Preparation of 2-(4-Methoxyphenyl)-1,3-dioxane (107)

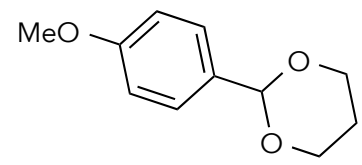

107

A solution of 1,3-propanediol $(6.81 \mathrm{~g}, 89.51 \mathrm{mmol})$ and para-anisaldehyde $(9.92 \mathrm{~g}$, $72.88 \mathrm{mmol})$ in toluene $(50 \mathrm{~mL})$ was treated with pTSA $(0.12 \mathrm{~g}, 0.73 \mathrm{mmol})$ and heated at reflux in a Dean-Stark apparatus overnight. The reaction mixture was then allowed to cool to room temperature, quenched with sat. aq. $\mathrm{NaHCO}_{3}(20 \mathrm{~mL})$ and washed with $\mathrm{H}_{2} \mathrm{O}(50 \mathrm{~mL} \times 2)$. The aqueous fraction was re-extracted with $\mathrm{Et}_{2} \mathrm{O}(30 \mathrm{~mL} \times 3)$, and the combined organic fractions were dried with $\mathrm{MgSO}_{4}$, filtered and concentrated in vacuo. Purification via silica gel flash column chromatography (5:1 PE:EtOAc) afforded the desired product $(12.08 \mathrm{~g}, 62.19 \mathrm{mmol}$, $85 \%)$ as an olive green crystalline solid. $\mathrm{R}_{\mathrm{f}}$ : 0.63 (1:1 PE:EtOAc). Melting point: $39.0-42.0^{\circ} \mathrm{C}$. ${ }^{1} \mathrm{H}$ NMR $\left(500 \mathrm{MHz}, \mathrm{CDCl}_{3}\right): \delta 7.40(\mathrm{~d}, J=7.3 \mathrm{~Hz}, 2 \mathrm{H}), 6.88(\mathrm{~d}, J=7.3 \mathrm{~Hz}, 2 \mathrm{H}), 5.46(\mathrm{~s}, 1 \mathrm{H})$, $4.25(\mathrm{dd}, J=12.0,4.9 \mathrm{~Hz}, 2 \mathrm{H}$ ), 3.98 (app. $\mathrm{t}, J=12.1 \mathrm{~Hz}, 2 \mathrm{H}$ ), $3.80(\mathrm{~s}, 3 \mathrm{H}), 2.26-2.17(\mathrm{~m}, 1 \mathrm{H}$ ), 1.43 (broad d, $J=13.4 \mathrm{~Hz}, 1 \mathrm{H}) .{ }^{13} \mathrm{C}$ NMR $\left(125 \mathrm{MHz}, \mathrm{CDCl}_{3}\right): \delta 159.9,131.3,127.3,113.6$, $101.6,67.4,55.3,25.8$. Spectral data match those reported in the literature. ${ }^{67}$

Preparation of 3-(4-Methoxybenzyloxy)propan-1-ol (108)

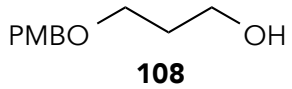

To a solution of acetal $107(0.77 \mathrm{~g}, 3.96 \mathrm{mmol})$ in DCM $(35 \mathrm{~mL})$ at $-78^{\circ} \mathrm{C}$ was added DIBAL (1M in cyclohexane, $8 \mathrm{~mL}, 8 \mathrm{mmol}$ ) over 15 minutes. The reaction mixture was allowed to warm to room temperature and stirred for 6 hours. The reaction was quenched with sat. aq. Rochelle's salt $(35 \mathrm{~mL})$ and the reaction mixture was stirred at room temperature overnight. The reaction mixture was extracted with EtOAc $(20 \mathrm{~mL} \times 3)$, and the combined organic fractions 
were washed with sat. aq. $\mathrm{NaCl}(30 \mathrm{~mL})$, dried with $\mathrm{MgSO}_{4}$, filtered and concentrated in vacuo. Purification via gradient silica gel flash column chromatography (2:1 PE:EtOAc - EtOAc) afforded the desired alcohol $(0.59 \mathrm{~g}, 3.02 \mathrm{mmol}, 76 \%)$ as a colourless oil. $\mathrm{R}_{\mathrm{f}}$ : 0.28 (1:1 PE:EtOAc). ${ }^{1} \mathrm{H}$ NMR (500 MHz, CDCl $\left.)_{3}\right): 8.25(\mathrm{~d}, J=8.5 \mathrm{~Hz}, 2 \mathrm{H}), 6.88(\mathrm{~d}, J=8.3 \mathrm{~Hz}, 2 \mathrm{H}), 4.45$ $(\mathrm{s}, 2 \mathrm{H}), 3.80(\mathrm{~s}, 3 \mathrm{H}), 3.78-3.77(\mathrm{~m}, 2 \mathrm{H}), 3.64(\mathrm{t}, J=5.7 \mathrm{~Hz}, 2 \mathrm{H}$ ), $2.28(\mathrm{bs}, 1 \mathrm{H}$ ), 1.85 (quin, $J=5.8$ $\mathrm{Hz}, 2 \mathrm{H}) .{ }^{13} \mathrm{C}$ NMR $\left(125 \mathrm{MHz}, \mathrm{CDCl}_{3}\right): \delta 159.3,130.1,129.3,113.8,72.9,69.2,62.1,55.3,32.0$. Spectral data match those reported in the literature. ${ }^{68}$

Preparation of 3-(4-Methoxybenzyloxy)propanal (109)

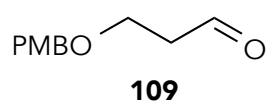

To a solution of alcohol $108(1.04 \mathrm{~g}, 5.30 \mathrm{mmol})$ in DCM $(35 \mathrm{~mL})$ and DMSO $(15 \mathrm{~mL})$ at $0{ }^{\circ} \mathrm{C}$ was added $\mathrm{NEt}_{3}(3.70 \mathrm{~mL}, 26.50 \mathrm{mmol})$ and the mixture was stirred for 1 hour. $\mathrm{SO}_{3}$.pyridine $(2.93 \mathrm{~g}, 18.41 \mathrm{mmol})$ was the added portion-wise over 10 minutes. The reaction mixture was allowed to stir for 2 hours, slowly warmed to room temperature and stirred for an additional 16 hours. The reaction mixture was then quenched with sat. aq. $\mathrm{NH}_{4} \mathrm{Cl}(35 \mathrm{~mL})$, and extracted with $\mathrm{DCM}(30 \mathrm{~mL} \times 3)$. The combined organic fractions were then washed with $10 \% \mathrm{HCl}(15 \mathrm{~mL}$ x 2), $\mathrm{H}_{2} \mathrm{O}(30 \mathrm{~mL})$ and sat. aq. $\mathrm{NaCl}(30 \mathrm{~mL})$, dried with $\mathrm{MgSO}_{4}$, filtered and concentrated in vacuo to afford the desired aldehyde $(1.00 \mathrm{~g}, 5.15 \mathrm{mmol}, 94 \%)$ as an orange oil, which was used in the next reaction without further purification. $R_{f}$ : 0.52 (1:1 PE:EtOAc). ${ }^{1} \mathrm{H} N M R$ $\left(500 \mathrm{MHz}, \mathrm{CDCl}_{3}\right): \delta 9.79(\mathrm{t}, J=1.8 \mathrm{~Hz}, 1 \mathrm{H}), 7.25(\mathrm{~d}, J=8.8 \mathrm{~Hz}, 2 \mathrm{H}), 6.88(\mathrm{~d}, J=8.5 \mathrm{~Hz}, 2 \mathrm{H})$, $4.46(\mathrm{~s}, 2 \mathrm{H}), 3.81(\mathrm{~s}, 3 \mathrm{H}), 3.79(\mathrm{t}, J=6.2 \mathrm{~Hz}, 2 \mathrm{H}), 2.73(\mathrm{td}, J=6.1,1.6 \mathrm{~Hz}, 2 \mathrm{H}) .{ }^{13} \mathrm{C}$ NMR $(125$ $\left.\mathrm{MHz}, \mathrm{CDCl}_{3}\right): \delta 201.3,159.3,129.9,129.4,113.8,72.9,63.5,55.3,43.9$. Spectral data match those reported in the literature..$^{68}$

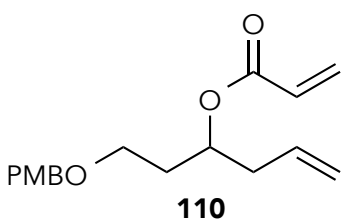


To a solution of aldehyde $109(1.27 \mathrm{~g}, 6.54 \mathrm{mmol})$ in $\operatorname{THF}(50 \mathrm{~mL})$ at $0{ }^{\circ} \mathrm{C}$ was added allylmagnesium bromide ( $1 \mathrm{M}$ in $\left.\mathrm{Et}_{2} \mathrm{O}, 8.5 \mathrm{~mL}, 8.5 \mathrm{mmol}\right)$. The reaction mixture was allowed to warm to room temperature and stirred overnight. An extra amount of allylmagnesium bromide ( $2 \mathrm{~mL}, 2 \mathrm{mmol}$ ) was added, as the reaction had not gone to completion, and stirred for an additional 6 hours. Without any purification, to the reaction mixture was added acryloyl chloride $(0.80 \mathrm{~mL}, 9.75 \mathrm{mmol}), \mathrm{NEt}_{3}(1.35 \mathrm{~mL}, 9.75 \mathrm{mmol})$ and DMAP $(0.16 \mathrm{~g}, 1.31 \mathrm{mmol})$ at $0{ }^{\circ} \mathrm{C}$, and the reaction was stirred at room temperature overnight. The reaction mixture was quenched with sat. aq. $\mathrm{NH}_{4} \mathrm{Cl}(40 \mathrm{~mL})$, and extracted with EtOAc $(30 \mathrm{~mL} \times 2)$. The organic fractions were then washed with $\mathrm{H}_{2} \mathrm{O}(30 \mathrm{~mL} \times 3)$, sat. aq. $\mathrm{NaCl}(30 \mathrm{~mL} \times 3)$, dried with $\mathrm{MgSO}_{4}$, filtered and concentrated in vacuo. The crude material was purified via silica gel flash column chromatography (10:1 PE:EtOAc) to provide the desired product $(0.79 \mathrm{~g}, 2.72 \mathrm{mmol}, 42 \%)$ as a colourless oil. $\mathrm{R}_{\mathrm{f}}: 0.78(1: 1 \mathrm{PE}: \mathrm{EtOAc}) .{ }^{1} \mathrm{H}$ NMR $\left(500 \mathrm{MHz}, \mathrm{CDCl}_{3}\right): \delta 7.24(\mathrm{~d}, J=8.3 \mathrm{~Hz}, 2 \mathrm{H})$, $6.86(d, J=8.3 \mathrm{~Hz}, 2 \mathrm{H}), 6.37(\mathrm{~d}, J=16.9 \mathrm{~Hz}, 1 \mathrm{H}), 6.11-6.06(\mathrm{~m}, 1 \mathrm{H}), 5.81-5.79(\mathrm{~m}, 1 \mathrm{H}), 5.76-$ $5.72(\mathrm{~m}, 1 \mathrm{H}), 5.18-5.14(\mathrm{~m}, 1 \mathrm{H}), 5.09-5.05$ (complex $\mathrm{m}, 2 \mathrm{H}), 4.40(\mathrm{~s}, 2 \mathrm{H}), 3.80(\mathrm{~s}, 3 \mathrm{H}), 3.52-3.43$ $(\mathrm{m}, 2 \mathrm{H}), 2.41-2.34(\mathrm{~m}, 2 \mathrm{H}), 1.92-1.87(\mathrm{~m}, 2 \mathrm{H}) .{ }^{13} \mathrm{C}$ NMR $\left(125 \mathrm{MHz}, \mathrm{CDCl}_{3}\right): \delta 165.7,159.1$, $133.4,130.5,130.4,129.3,128.7,118.0,113.8,72.7,71.0,66.2,55.3,38.8,33.8$. Spectral data match those reported in the literature. ${ }^{69}$

Preparation of ( \pm )-6-(2-(4-Methoxybenzyloxy)ethyl)-5,6-dihydro-2H-pyran-2-one (111)

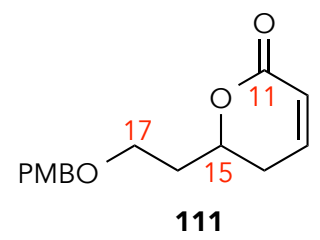

To a solution of diene $110(0.34 \mathrm{~g}, 1.18 \mathrm{mmol})$ in $\mathrm{DCM}(50 \mathrm{~mL})$ at room temperature was added Grubbs $2^{\text {nd }}$ generation catalyst $(0.05 \mathrm{~g}, 0.06 \mathrm{mmol}$, made into a solution with $2 \mathrm{~mL}$ $D C M)$ in two portions $(1 \mathrm{~mL} \times 2)$ over 14 hours. The reaction mixture was then refluxed for 3 hours, and the solvent was removed in vacuo. Purification of the mixture via gradient silica gel flash column chromatography (9:1 PE:EtOAc - 1:1 PE:EtOAc) afforded the desired product $(0.24 \mathrm{~g}, 0.92 \mathrm{mmol}, 78 \%)$ as a clear oil contaminated with some Grubbs $2^{\text {nd }}$ generation catalyst. Rf: 0.32 (1:1 PE:EtOAc). ${ }^{1} \mathrm{H}$ NMR (500 MHz, $\left.\mathrm{CDCl}_{3}\right): \delta 7.25$ (d, J=8.3 Hz, 2H, CH arom.), 6.886.85 (complex m, 3H, CH arom, H-13), $6.03(\mathrm{~d}, J=9.8 \mathrm{~Hz}, 1 \mathrm{H}, \mathrm{H}-12), 4.66-4.60(\mathrm{~m}, 1 \mathrm{H}, \mathrm{H}-15)$, 
$4.46\left(\mathrm{~d}, J=11.5 \mathrm{~Hz}, 1 \mathrm{H}, \mathrm{PMB}-\mathrm{CH}_{2}\right), 4.42\left(\mathrm{~d}, J=11.5 \mathrm{~Hz}, 1 \mathrm{H}, \mathrm{PMB}-\mathrm{CH}_{2}\right), 3.81\left(\mathrm{~s}, 3 \mathrm{H}, \mathrm{OCH}_{3}\right)$, 3.70-3.65 (m, 1H, C-17), 3.63-3.59 (m, 1H, C-17), 2.37-2.35 (m, 2H, H-14), 2.10-2.03 (m, 1H, H16), 1.97-1.91 (m, 1H, H-16). ${ }^{13} \mathrm{C}$ NMR (125 MHz, $\left.\mathrm{CDCl}_{3}\right): \delta 164.4$ (C-18), 159.3 (C arom.), 145.1 (C-13), 130.2 (C arom.), 129.4 ( $\mathrm{CH}$ arom.), 121.4 (C-12), 113.8 (CH arom.), 75.3 (C-15), $72.9\left(\mathrm{PMB}-\mathrm{CH}_{2}\right), 65.3(\mathrm{C}-17), 55.3\left(\mathrm{OCH}_{3}\right), 35.1(\mathrm{C}-16), 29.6(\mathrm{C}-14)$. IR (neat) $\mathrm{cm}^{-1}: 1715(\mathrm{C}=\mathrm{O})$, $1612(\mathrm{C}=\mathrm{C}), 1512(\mathrm{C}=\mathrm{C}), 1243(\mathrm{C}-\mathrm{O}), 1086(\mathrm{C}-\mathrm{O}) . \mathrm{HRMS}-\mathrm{ESI}(\mathrm{m} / \mathrm{z}):\left[\mathrm{M}+\mathrm{NH}_{4}\right]^{+}$calculated for $\mathrm{C}_{15} \mathrm{H}_{22} \mathrm{NO}_{4}{ }^{+}, 280.1543$; found 280.1542 .

Preparation of ( \pm )-6-(2-Hydroxyethyl)-5,6-dihydro-2H-pyran-2-one (98)<smiles>O=C1C=CCC(CCO)O1</smiles>

To a solution of lactone $111(34.9 \mathrm{mg}, 0.13 \mathrm{mmol})$ in 10:1 DCM: $\mathrm{H}_{2} \mathrm{O}(4 \mathrm{~mL})$ at room temperature was added DDQ $(36.6 \mathrm{mg}, 0.16 \mathrm{mmol})$, and the mixture was stirred overnight. The mixture was then filtered and rinsed with $\mathrm{DCM}$, dried with $\mathrm{MgSO}_{4}$, filtered and concentrated in vacuo. The crude product was purified via gradient silica gel flash column chromatography $5: 1$ PE:EtOAc - 1:1 PE:EtOAc) to afford the desired lactone (14.7 mg, $0.10 \mathrm{mmol}, 79 \%)$ as a colourless oil. $R_{f}: 0.26$ (EtOAc). ${ }^{1} \mathrm{H}$ NMR $\left(500 \mathrm{MHz}, \mathrm{CDCl}_{3}\right): \delta 6.91(\mathrm{dt}, J=9.7,4.3 \mathrm{~Hz}, 1 \mathrm{H})$, $6.04(\mathrm{dt}, J=9.7,1.8 \mathrm{~Hz}, 1 \mathrm{H}), 4.70-4.65(\mathrm{~m}, 1 \mathrm{H}), 3.94-3.89(\mathrm{~m}, 1 \mathrm{H}), 3.87-3.82(\mathrm{~m}, 1 \mathrm{H}), 2.42-2.39$ $(\mathrm{m}, 2 \mathrm{H}), 2.08-2.01(\mathrm{~m}, 1 \mathrm{H}), 1.95-1.89(\mathrm{~m}, 1 \mathrm{H}), 1.74$ (bs, $1 \mathrm{H}) .{ }^{13} \mathrm{C} \mathrm{NMR}\left(125 \mathrm{MHz}, \mathrm{CDCl}_{3}\right): \delta$ 164.2, 145.2, 121.4, 75.6, 58.6, 37.3, 29.6. HRMS-ESI (m/z): $[\mathrm{M}+\mathrm{H}]^{+}$calculated for $\mathrm{C}_{7} \mathrm{H}_{11} \mathrm{O}_{3}{ }^{+}$, 143.0703; found 143.0703. Spectral data match those reported in the literature. ${ }^{70}$

\subsubsection{Synthesis of Thioamide Fragment 131}

Preparation of 3-((tert-Butyldiphenylsilyl)oxy)propionitrile (134)

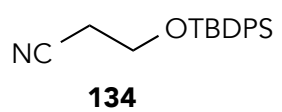


To a solution of 3-hydroxypropionitrile $(1.00 \mathrm{~mL}, 14.63 \mathrm{mmol})$ in DMF $(50 \mathrm{~mL})$ at $0{ }^{\circ} \mathrm{C}$ was added imidazole $(1.30 \mathrm{~g}, 19.07 \mathrm{mmol})$ and the mixture was stirred for 15 minutes. TBDPSCl (4.20 mL, $16.09 \mathrm{mmol}$ ) was added dropwise over 15 minutes, and the reaction mixture was then stirred for 4.5 hours, gradually warming to room temperature. The reaction mixture was then quenched with $\mathrm{EtOAc}(30 \mathrm{~mL})$, washed with sat. aq. $\mathrm{NaHCO}_{3}(30 \mathrm{~mL})$, and the resulting milky white aqueous layer was extracted with EtOAc $(30 \mathrm{~mL})$. The organic fraction was washed with sat. aq. $\mathrm{NaHCO}_{3}(30 \mathrm{~mL} \times 3), \mathrm{H}_{2} \mathrm{O}(30 \mathrm{~mL})$ and sat. aq. $\mathrm{NaCl}(30 \mathrm{~mL})$, dried with $\mathrm{MgSO}_{4}$, filtered and concentrated in vacuo, affording the desired nitrile $(4.57 \mathrm{~g}, 14.76 \mathrm{mmol}, 100 \%)$ as a pale yellow oil. $\mathrm{R}_{\mathrm{f}}$ : 0.79 (2:1 PE:EtOAc). ${ }^{1} \mathrm{H}$ NMR $\left(500 \mathrm{MHz}, \mathrm{CDCl}_{3}\right): \delta$ 7.68-7.66 (m, 4H), 7.48-7.44 (m, 2H), 7.42-7.40 (m, 4H), $3.85(t, J=6.2 \mathrm{~Hz}, 2 \mathrm{H}), 2.55(\mathrm{t}, J=6.4 \mathrm{~Hz}, 2 \mathrm{H}), 1.08(\mathrm{~s}$, 9H). ${ }^{13} \mathrm{C}$ NMR $\left(125 \mathrm{MHz}, \mathrm{CDCl}_{3}\right): \delta 135.5,132.7,130.0,127.9,118.0,59.0,26.7,21.5,19.1$. Spectral data match those reported in the literature. ${ }^{71}$

Preparation of 3-((tert-Butyldiphenylsilyl)oxy)propanamide (135)

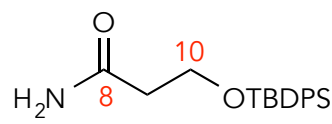

135

To a solution of nitrile $134(4.57 \mathrm{~g}, 14.76 \mathrm{mmol})$ in DMSO $(50 \mathrm{~mL})$ at $0{ }^{\circ} \mathrm{C}$ was added $\mathrm{H}_{2} \mathrm{O}_{2}$ $(30 \%, 11.50 \mathrm{~mL}, 383.6 \mathrm{mmol})$ dropwise over 20 minutes. $\mathrm{K}_{2} \mathrm{CO}_{3}(0.43 \mathrm{~g}, 3.10 \mathrm{mmol})$ was then added. The reaction mixture was then warmed to room temperature and stirred for 2.5 hours. The reaction was then quenched with $\mathrm{H}_{2} \mathrm{O}(50 \mathrm{~mL})$, producing a white precipitate. The reaction mixture was extracted with EtOAc $(30 \mathrm{~mL} \times 3)$, and the combined organic fractions were washed with $\mathrm{H}_{2} \mathrm{O}(30 \mathrm{~mL})$ and sat. aq. $\mathrm{NaCl}(30 \mathrm{~mL})$, dried with $\mathrm{MgSO}_{4}$, filtered and concentrated in vacuo. The crude product was purified via gradient silica gel flash column chromatography (2:1 PE:EtOAc - 1:1 PE:EtOAc) to afford the desired amide $(4.57 \mathrm{~g}$, $13.95 \mathrm{mmol}, 94 \%)$ as a white solid. $\mathrm{R}_{\mathrm{f}}$ : 0.18 (2:1 EtOAc:PE). Melting point: $96.0-97.0^{\circ} \mathrm{C} .{ }^{1} \mathrm{H}$ NMR $\left(500 \mathrm{MHz} \mathrm{CDCl}_{3}\right): \delta 7.66(\mathrm{dd}, J=6.3,1.5 \mathrm{~Hz}, 4 \mathrm{H}, \mathrm{CH}$ arom.), 7.47-7.39 (m, 6H, CH arom.), 6.44 (bs, 1H, NH), 5.34 (bs, 1H, NH), $3.93(t, J=5.7 \mathrm{~Hz}, 2 \mathrm{H}, \mathrm{H}-10), 2.45(t, J=5.7 \mathrm{~Hz}$, 2H, H-9), 1.56 (s, 9H, CH $\mathrm{tBu}^{\mathrm{H}} .{ }^{13} \mathrm{C}$ NMR (125 MHz, CDCl 3 ): $\delta 174.1$ (C-8), 135.5 (CH arom.), 132.8 (C arom.), 130.0 ( $\mathrm{CH}$ arom,), 127.9 ( $\mathrm{CH}$ arom.), 60.3 (C-10), 38.9 (C-9), 26.8 ( $\left.\mathrm{CH}_{3} \mathrm{tBu}\right)$, 19.1 (C tBu). IR (neat) cm²: $3463(\mathrm{~N}-\mathrm{H}), 2963(\mathrm{C}-\mathrm{H}), 1663(\mathrm{C}=\mathrm{O}), 1473(\mathrm{C}=\mathrm{C})$. HRMS-ESI (m/z): $[\mathrm{M}+\mathrm{Na}]^{+}$calculated for $\mathrm{C}_{19} \mathrm{H}_{25} \mathrm{NNaO}_{2} \mathrm{Si}^{+}, 350.1547$; found 350.1548 . 
<smiles>NC(=S)C[C+]O[PbH2]</smiles>

131

To a solution of amide $135(0.26 \mathrm{~g}, 0.79 \mathrm{mmol})$ in THF $(15 \mathrm{~mL})$ at room temperature was added Lawesson's reagent $(0.22 \mathrm{~g}, 0.55 \mathrm{mmol})$. The reaction mixture was stirred for 1 hour, and then quenched with sat. aq. $\mathrm{NaCl}(20 \mathrm{~mL})$, and extracted with $\mathrm{EtOAc}(30 \mathrm{~mL} \times 3)$. The combined organic fractions were washed with sat. aq. $\mathrm{NaCl}(30 \mathrm{~mL})$, dried with $\mathrm{MgSO}_{4}$, filtered, and concentrated in vacuo. The product was then purified via gradient silica gel flash column chromatography (5:1 PE:EtOAc - 3:1 PE:EtOAc) to obtain the desired thioamide $(0.12 \mathrm{~g}, 0.36 \mathrm{mmol}, 46 \%)$ as a yellow crystalline solid. $\mathrm{R}_{\mathrm{f}}$ : 0.43 (2:1 PE:EtOAc). Melting point: 87.3-88.0 ${ }^{\circ} \mathrm{C} .{ }^{1} \mathrm{H}$ NMR $\left(500 \mathrm{MHz}, \mathrm{CDCl}_{3}\right.$ ): $\delta 8.11$ (bs, $\left.1 \mathrm{H}, \mathrm{NH}\right), 7.64(\mathrm{~d}, J=7.8 \mathrm{~Hz}, 4 \mathrm{H}, \mathrm{CH}$ arom.), 7.48-7.40 (m, 6H, CH arom.), 3.97 ( $\mathrm{t}, J=5.4 \mathrm{~Hz}, 2 \mathrm{H}, \mathrm{H}-10), 2.94(\mathrm{t}, J=5.5 \mathrm{~Hz}, 2 \mathrm{H}, \mathrm{H}-9$ ), 1.07 (s, 9H, CH $\left.\mathrm{CH}_{3} \mathrm{Bu}\right) .{ }^{13} \mathrm{C}$ NMR (125 MHz, $\left.\mathrm{CDCl}_{3}\right): \delta 208.8$ (C-8), $135.4(\mathrm{CH}$ arom.), 132.4 (C arom.), 130.1 ( $\mathrm{CH}$ arom.), 128.0 ( $\mathrm{CH}$ arom.), 62.2 (C-10), 47.6 (C-9), $26.9\left(\mathrm{CH}_{3} \mathrm{tBu}\right), 19.1$ (C tBu). IR: (neat) $\mathrm{cm}^{-1}$ : $3416(\mathrm{~N}-\mathrm{H}), 2955(\mathrm{C}-\mathrm{H}), 1626(\mathrm{~N}-\mathrm{H})$. HRMS-ESI $(\mathrm{m} / \mathrm{z}):[\mathrm{M}+\mathrm{H}]^{+}$calculated for $\mathrm{C}_{19} \mathrm{H}_{26} \mathrm{NOSSi}^{+}, 344.1499$; found 344.1485.

\subsubsection{Thiazole Formation Model Reaction}

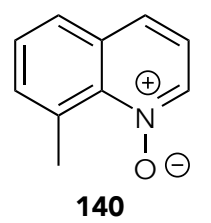

To a solution of 8 -methylquinoline $(0.14 \mathrm{~g}, 0.98 \mathrm{mmol})$ in DCM $(10 \mathrm{~mL})$ was added $\mathrm{mCPBA}$ $(0.37 \mathrm{~g}, 1.3 \mathrm{mmol})$ and the mixture was stirred at room temperature for 24 hours. The reaction mixture was then quenched with $\mathrm{KOH}(1 \mathrm{M}, 10 \mathrm{~mL})$, and extracted with $\mathrm{DCM}(10 \mathrm{~mL} \times 3)$. The combined organic extracts were then washed with sat. aq. $\mathrm{NaCl}(10 \mathrm{~mL})$, dried with $\mathrm{MgSO}_{4}$, filtered and concentrated in vacuo. The crude material was purified via gradient silica gel flash column chromatography (2:1 PE:EtOAc - 9:1 EtOAc:MeOH) to afford the $\mathrm{N}$-oxide $(0.13 \mathrm{~g}$, 
$0.81 \mathrm{mmol}, 81 \%)$ as an orange oil. $\mathrm{R}_{\mathrm{f}}: 0.26(9: 1 \mathrm{EtOAc:MeOH}) .{ }^{1} \mathrm{H} \mathrm{NMR}\left(500 \mathrm{MHz}, \mathrm{CDCl}_{3}\right): \delta$ $8.41(d, J=6.1 \mathrm{~Hz}, 1 \mathrm{H}), 7.66-7.64($ complex $m, 2 \mathrm{H}), 7.45-7.41(\mathrm{~m}, 2 \mathrm{H}), 7.19(\mathrm{dd}, J=8.5,6.1 \mathrm{~Hz}$, 1H), $3.19(\mathrm{~s}, 3 \mathrm{H}) .{ }^{13} \mathrm{C}$ NMR $\left(125 \mathrm{MHz}, \mathrm{CDCl}_{3}\right): \delta 141.4,137.4,133.7,133.4,132.5,128.1$, $126.8,126.5,120.7,24.9$. Spectral data match those reported in the literature. ${ }^{61}$

Preparation of Propanethioamide (142)

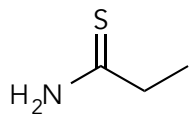

142

To a solution of propanamide $(1.20 \mathrm{~g}, 16.42 \mathrm{mmol})$ in THF $(55 \mathrm{~mL})$ at room temperature was added Lawesson's reagent $(4.53 \mathrm{~g}, 11.20 \mathrm{mmol})$. The reaction mixture was stirred for 4.5 hours, and then quenched with sat. aq. $\mathrm{NaCl}(40 \mathrm{~mL})$, and extracted with EtOAc $(40 \mathrm{~mL} \times 2)$. The combined organic extracts were then washed with sat. aq. $\mathrm{NaCl}(20 \mathrm{~mL} \times 2)$, dried with $\mathrm{MgSO}_{4}$, filtered and concentrated in vacuo. The crude material was then purified via gradient silica gel flash column chromatography (10:1 PE:EtOAc - 3:1 PE:EtOAc) to provide the desired product (0.94 $\mathrm{g}, 10.54 \mathrm{mmol}, 64 \%)$ as a yellow crystalline solid. $\mathrm{R}_{\mathrm{f}}$ : 0.34 (1:1 PE:EtOAc). ${ }^{1} \mathrm{H}$ NMR (500 MHz, $\left.\mathrm{CDCl}_{3}\right): \delta 7.38$ (bs, 1H), 6.79 (bs, 1H), $2.70(q, J=7.5 \mathrm{~Hz}, 2 \mathrm{H}), 1.32(\mathrm{t}, J=7.5 \mathrm{~Hz}$, $3 \mathrm{H}) .{ }^{13} \mathrm{C}$ NMR $\left(125 \mathrm{MHz}, \mathrm{CDCl}_{3}\right): \delta 212.3,38.3,13.3$. Spectral data match those reported in the literature. ${ }^{72}$

Preparation of 2-Ethyl-4-phenylthiazole (143)

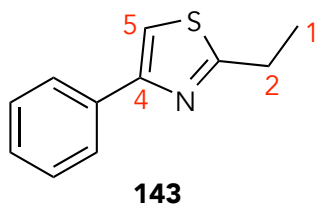

To a solution of phenylacetylene $(23.0 \mathrm{mg}, 0.23 \mathrm{mmol})$ in DCM $(1 \mathrm{~mL})$ under argon was added Mor-DalPhosAuNTf $2(10.5 \mathrm{mg}, 0.01 \mathrm{mmol})$, and the green solution was stirred at room temperature for 45 minutes. To the reaction mixture a solution of 8-methylquinoline $\mathrm{N}$-oxide $140(47.9 \mathrm{mg}, 0.30 \mathrm{mmol})$ and methanesulfonic acid $(27 \mathrm{mg}, 0.28 \mathrm{mmol})$ in DCM (0.5 mL) was added dropwise over 3.5 hours. The yellow solution was further stirred for an hour, followed by addition of thioamide $142(25.8 \mathrm{mg}, 0.29 \mathrm{mmol})$, and stirred at $40{ }^{\circ} \mathrm{C}$ overnight. The reaction 
mixture was washed with sat. aq. $\mathrm{NaHCO}_{3}(3 \mathrm{~mL} \times 3)$, sat. aq. $\mathrm{NH}_{4} \mathrm{Cl}(3 \mathrm{~mL} \times 2)$, sat. aq. $\mathrm{NaCl}$ $(3 \mathrm{~mL})$, dried with $\mathrm{MgSO}_{4}$, filtered and concentrated in vacuo. The crude material was then purified via gradient silica gel flash column chromatography (PE - 20:1 PE:EtOAc) to provide the product $(5.4 \mathrm{mg}, 0.03 \mathrm{mmol}, 12 \%)$ as a yellow oil. $\mathrm{R}_{\mathrm{f}}$ : 0.68 (3:1 PE:EtOAc). ${ }^{1} \mathrm{H}$ NMR (500 MHz, $\mathrm{CDCl}_{3}$ ): $\delta 7.89$ (d, J = 7.3 Hz, 2H, CH arom.), 7.42 (d, J = 7.6 Hz, 2H, CH arom.), 7.33-7.31 (m, 2H, CH arom., H-5), $3.10(q, J=7.6 \mathrm{~Hz}, 2 \mathrm{H}, \mathrm{H}-2), 1.45(\mathrm{t}, J=7.6 \mathrm{~Hz}, 3 \mathrm{H}, \mathrm{H}-1)$. ${ }^{13} \mathrm{C}$ NMR (125 MHz, CDCl 3 ): $\delta 172.8$ (C-3), 155.0 (C-4), 134.7 (C arom.), 128.7 (CH arom.), 127.9 (CH arom.), 126.4 (CH arom.), 111.7 (C-5), 27.1 (C-2), 14.2 (C-1). IR: (neat) cm ${ }^{-1}: 3027$ (CH), $1499(\mathrm{C}=\mathrm{C}), 692(\mathrm{C}-\mathrm{S})$. HRMS-ESI (m/z): $[\mathrm{M}+\mathrm{H}]^{+}$calculated for $\mathrm{C}_{11} \mathrm{H}_{12} \mathrm{NS}^{+}, 190.0685$; found 190.0688 .

\subsubsection{Synthesis of Analogue 130}

Preparation of ( \pm )-2-(6-Oxo-3,6-dihydro-2H-pyran-2-yl)ethyl hept-6-ynoate (126)

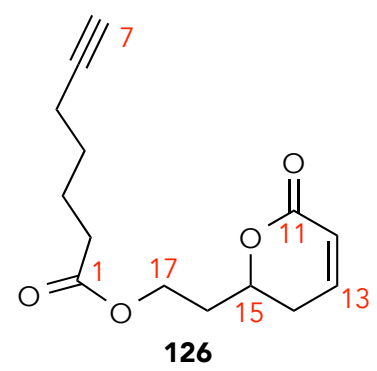

To a solution of alcohol $98(7.8 \mathrm{mg}, 0.06 \mathrm{mmol})$ and 6-heptanoic acid $(8.3 \mathrm{mg}, 0.07 \mathrm{mmol})$ in $\operatorname{DCM}(2.1 \mathrm{~mL})$ at $0{ }^{\circ} \mathrm{C}$ was added $\operatorname{EDCl}(16.8 \mathrm{mg}, 0.09 \mathrm{mmol})$ followed by DMAP $(4.2 \mathrm{mg}$, $0.03 \mathrm{mmol})$. The reaction mixture was stirred for $25 \mathrm{~h}$ at room temperature, and then quenched with sat. aq. $\mathrm{NH}_{4} \mathrm{Cl}(3 \mathrm{~mL})$, and extracted with $\mathrm{DCM}(5 \mathrm{~mL} \times 4)$. The organic extracts were then washed with sat. aq. $\mathrm{NaHCO}_{3}(10 \mathrm{~mL} \times 2)$, and sat. aq. $\mathrm{NaCl}(10 \mathrm{~mL})$, dried with $\mathrm{MgSO}_{4}$, filtered and concentrated in vacuo. The crude material was purified via gradient silica gel flash column chromatography (5:1 PE:EtOAc - 1:1 PE:EtOAc) to provide the desired product (11.9 mg, $0.05 \mathrm{mmol}, 86 \%)$ as a colourless oil. $\mathrm{R}_{\mathrm{f}}: 0.33$ (1:1 PE:EtOAc). ${ }^{1} \mathrm{H} \mathrm{NMR}\left(500 \mathrm{MHz}, \mathrm{CDCl}_{3}\right): \delta$ 6.91-6.88 (m, 1H, H-13), $6.04(\mathrm{dt}, J=9.8,1.2 \mathrm{~Hz}, 1 \mathrm{H}, \mathrm{H}-12), 4.60-4.54(\mathrm{~m}, 1 \mathrm{H}, \mathrm{H}-15), 4.33-4.29$ $(m, 1 H, H-17), 4.27-4.22(m, 1 H, H-17), 2.40-2.37(m, 2 H, H-14), 2.34(t, J=7.6 \mathrm{~Hz}, 2 \mathrm{H}, \mathrm{H}-2)$, $2.21(\mathrm{td}, J=7.2,1.4 \mathrm{~Hz}, 2 \mathrm{H}, \mathrm{H}-5), 2.15-2.09(\mathrm{~m}, 1 \mathrm{H}, \mathrm{H}-16), 2.03-1.97(\mathrm{~m}, 1 \mathrm{H}, \mathrm{H}-16), 1.95(\mathrm{t}, J$ $=2.6 \mathrm{~Hz}, 1 \mathrm{H}, \mathrm{H}-7), 1.78-1.71(\mathrm{~m}, 2 \mathrm{H}, \mathrm{H}-3), 1.59-1.53(\mathrm{~m}, 2 \mathrm{H}, \mathrm{H}-4) .{ }^{13} \mathrm{C} \mathrm{NMR}\left(125 \mathrm{MHz}, \mathrm{CDCl}_{3}\right)$ : 


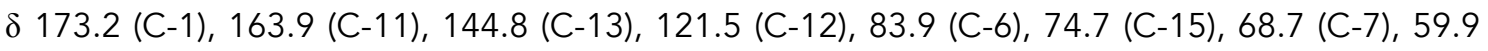
(C-17), 34.0 (C-16), 33.6 (C-2), 29.4 (C-14), 27.8 (C-4), 23.9 (C-3), 18.1 (C-5). IR: (neat) cm-1: $3277(\equiv \mathrm{C}-\mathrm{H}), 1718(\mathrm{C}=\mathrm{O})$. HRMS-ESI $(\mathrm{m} / \mathrm{z}):[\mathrm{M}+\mathrm{Na}]^{+}$calculated for $\mathrm{C}_{14} \mathrm{H}_{18} \mathrm{NaO}_{4}{ }^{+}, 273.1097$; found 273.1097 .

Preparation of ( \pm )-2-(6-Oxo-3,6-dihydro-2H-pyran-2-yl)ethyl 5-(2-(2-((tertbutyldiphenylsilyl)oxy)ethyl)thiazol-4-yl)pentanoate (136)

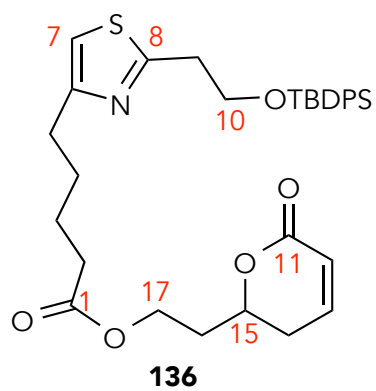

To a solution of $126(143.9 \mathrm{mg}, 0.57 \mathrm{mmol})$ in DCM $(1.15 \mathrm{~mL})$ under argon was added MorDalPhosAuNTf $(39.9 \mathrm{mg}, 0.04 \mathrm{mmol})$ and the mixture was stirred at room temperature for 45 minutes. To this vial a solution of 8 -methylquinoline $\mathrm{N}$-oxide $140(120.0 \mathrm{mg}, 0.75 \mathrm{mmol})$ and pTSA (115.6 mg, $0.67 \mathrm{mmol}$, recrystallised from $\mathrm{Et}_{2} \mathrm{O}$ and PE) in DCM (1.65 mL) was added over 6 hours. Thioamide $131(252.0 \mathrm{mg}, 0.73 \mathrm{mmol}$ ) was added, and the reaction mixture was heated to $40{ }^{\circ} \mathrm{C}$ for 19 hours. The crude material was concentrated in vacuo, and then purified via gradient silica gel flash column chromatography $(9: 1$ n-hexane:EtOAc - 2:1 nhexane:EtOAc) to provide the desired product ( $95.7 \mathrm{mg}, 0.16 \mathrm{mmol}, 28 \%$ and $51 \%$ BRSM) as a yellow oil. Rf: 0.26 (1:1 PE:EtOAc). ${ }^{1} \mathrm{H}$ NMR $\left(500 \mathrm{MHz}, \mathrm{CDCl}_{3}\right): \delta$ 7.63-7.62 (m, 4H, $\mathrm{CH}$ arom.), 7.44-7.35 (m, 6H, CH arom.), 6.89-6.86 (m, 1H, H-13), $6.78(\mathrm{~s}, 1 \mathrm{H}, \mathrm{H}-7), 6.04(\mathrm{~d}, J=9.7 \mathrm{~Hz}, 1 \mathrm{H}$, $H-12)$, 4.58-4.53 (m, 1H, H-15), 4.33-4.28 (m, 1H, H-17), 4.26-4.21 (m, 1H, H-17), $3.98(t, J=6.2$ $\mathrm{Hz}, 2 \mathrm{H}, \mathrm{H}-10), 3.22(\mathrm{t}, J=6.1 \mathrm{~Hz}, 2 \mathrm{H}, \mathrm{H}-9), 2.77-2.74(\mathrm{~m}, 2 \mathrm{H}, \mathrm{H}-5), 2.38-2.33$ (complex m, 4H, $\mathrm{H}-14, \mathrm{H}-2), 2.14-2.08(\mathrm{~m}, 1 \mathrm{H}, \mathrm{H}-16), 2.02-1.96(\mathrm{~m}, 1 \mathrm{H}, \mathrm{H}-16), 1.73-1.69(\mathrm{~m}, 4 \mathrm{H}, \mathrm{H}-3, \mathrm{H}-4), 1.03$ (s, 9H, CH $\mathrm{tBu}^{\mathrm{B}} .{ }^{13} \mathrm{C}$ NMR (125 MHz, CDCl $): \delta 173.4$ (C-1), 167.5 (C-8), 163.9 (C-11), 156.0 (C6), 144.8 (C-13), 135.6 ( $\mathrm{CH}$ arom.), 133.4 (C arom.), 129.7 ( $\mathrm{CH}$ arom.), 127.7 ( $\mathrm{CH}$ arom.), 121.5 (C-12), 112.8 (C-7), 74.7 (C-15), 63.0 (C-10), 59.8 (C-17), 36.7 (C-9), 34.01 (C-16), 34.0 (C-2), 31.1 (C-5), 29.4 (C-14), 28.7 (C-3/4), 26.8 ( $\left.\mathrm{CH}_{3}, \mathrm{t}-\mathrm{Bu}\right), 24.5$ (C-3/4), 19.2 (t-Bu). IR: (neat) $\mathrm{cm}^{-1}$ : $1720(\mathrm{C}=\mathrm{O}), 1629(\mathrm{C}=\mathrm{C}), 1428(\mathrm{C}=\mathrm{C}), 1196(\mathrm{C}-\mathrm{O}) . \mathrm{HRMS}-\mathrm{ESI}(\mathrm{m} / \mathrm{z}):[\mathrm{M}+\mathrm{H}]^{+}$calculated for $\mathrm{C}_{33} \mathrm{H}_{42} \mathrm{NO}_{5} \mathrm{SSi}^{+}, 592.2547$; found 592.2573. 


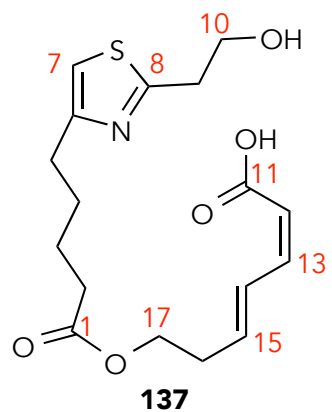

To a solution of thiazole $136(82.1 \mathrm{mg}, 0.14 \mathrm{mmol})$ in THF $(3 \mathrm{~mL})$ at room temperature was added TBAF (1M in THF, $0.28 \mathrm{~mL}, 0.97 \mathrm{mmol}$ ) over 3 minutes, and the reaction mixture was stirred overnight. The solvent was then removed in vacuo, and the product was purified via gradient silica gel flash column chromatography (5:1 n-hexane:EtOAc - 1:100 acetic acid:EtOAc) to provide the desired product $(35.2 \mathrm{mg}, 0.10 \mathrm{mmol}, 72 \%)$ as a yellow oil. $\mathrm{R}_{f}: 0.36$ (EtOAc). ${ }^{1} \mathrm{H}$ NMR (500 MHz, CDCl 3 ): $\delta 7.38$ (dd, $\left.J=15.0,11.9 \mathrm{~Hz}, 1 \mathrm{H}, \mathrm{H}-14\right), 6.80(\mathrm{~s}, 1 \mathrm{H}, \mathrm{H}-7$ ), 6.60 (app. $t, J=11.4 \mathrm{~Hz}, 1 \mathrm{H}, \mathrm{H}-13$ ), 6.07 (dt, $J=15.2,6.6 \mathrm{~Hz}, 1 \mathrm{H}, \mathrm{H}-15), 5.61$ (d, $J=11.3 \mathrm{~Hz}$, $1 \mathrm{H}, \mathrm{H}-12), 4.23(\mathrm{t}, J=5.8 \mathrm{~Hz}, 2 \mathrm{H}, \mathrm{H}-17), 4.01(\mathrm{t}, J=5.7 \mathrm{~Hz}, 2 \mathrm{H}, \mathrm{H}-10), 3.25(\mathrm{t}, J=5.5 \mathrm{~Hz}, 2 \mathrm{H}$, H-9), $2.75(t, J=6.9 \mathrm{~Hz}, 2 \mathrm{H}, \mathrm{H}-5), 2.53$ (app. q, J=5.9 Hz, 2H, H-16), $2.36(t, J=6.7 \mathrm{~Hz}, 2 \mathrm{H}, \mathrm{H}-$ 2), 1.73-1.69 (m, 4H, H-3, H-4). ${ }^{13} \mathrm{C} \mathrm{NMR} \mathrm{(125} \mathrm{MHz,} \mathrm{CDCl} 3$ ): $\delta 173.5$ (C-1), 169.0 (C-8), 155.8 (C-6), 144.7 (C-13), 139.6 (C-15), 128.9 (C-14), 117.2 (C-12), 113.0 (C-7), 62.2 (C-17), 61.5 (C10), 35.2 (C-9), 34.1 (C-2), 31.5 (C-16), 30.4 (C-5), 29.0 (C3/4), 24.4 (C3/4). IR: (neat) cm-1: 3104 $(=\mathrm{CH}), 1730(\mathrm{C}=\mathrm{O}), 1640(\mathrm{C}=\mathrm{C}), 1189(\mathrm{C}-\mathrm{O}) . \mathrm{HRMS}-\mathrm{ESI}(\mathrm{m} / \mathrm{z}):[\mathrm{M}+\mathrm{H}]^{+}$calculated for $\mathrm{C}_{17} \mathrm{H}_{24} \mathrm{NO}_{5} \mathrm{~S}^{+}, 354.1370$; found 354.1360 . 


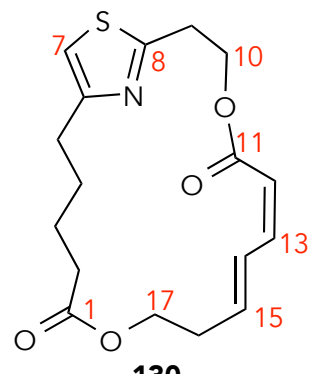

To a solution of seco acid $137(25.4 \mathrm{mg}, 0.07 \mathrm{mmol})$ in THF $(4 \mathrm{~mL})$ was added $\mathrm{NEt}_{3}(19.5 \mu \mathrm{L}$, $0.14 \mathrm{mmol})$ followed by TCBC $(17.2 \mu \mathrm{L}, 0.11 \mathrm{mmol})$ at room temperature. After 2.3 hours the solution was cooled to $-78{ }^{\circ} \mathrm{C}$, and DCM was added $(20.5 \mathrm{~mL})$, followed by DMAP $(2.7 \mathrm{mg}$, $0.02 \mathrm{mmol}$ ). The reaction mixture was left to warm to room temperature after 2 hours, and stirred overnight. The reaction mixture was then quenched with sat. aq. $\mathrm{NH}_{4} \mathrm{Cl}(15 \mathrm{~mL})$ and extracted with DCM (15 mL x 3). The combined organic fractions were then washed with sat. aq. $\mathrm{NaHCO}_{3}(20 \mathrm{~mL} \times 3)$, sat. aq. $\mathrm{NaCl}(20 \mathrm{~mL})$, dried with $\mathrm{MgSO}_{4}$, filtered and concentrated in vacuo. The crude material was purified via gradient silica gel flash column chromatography (10:1 n-hexane:EtOAc - 6:1 n-hexane:EtOAc) to provide the desired analogue 130 (3.2 mg, $0.01 \mathrm{mmol}, 14 \%)$ as a yellow oil. Rf: 0.65 (EtOAc). ${ }^{1} \mathrm{H}$ NMR $\left(500 \mathrm{MHz}, \mathrm{CDCl}_{3}\right.$ ): $\delta 7.09$ (dd, $J=$ 15.1, $11.7 \mathrm{~Hz}, 1 \mathrm{H}, \mathrm{H}-14), 6.76(\mathrm{~s}, 1 \mathrm{H}, \mathrm{H}-7), 6.47$ (app. $\mathrm{t}, J=11.4 \mathrm{~Hz}, 1 \mathrm{H}, \mathrm{H}-13), 5.92(\mathrm{dt}, J=$ 15.1, 7.5 Hz, 1H, H-15), $5.52(d, J=11.5 \mathrm{~Hz}, 1 \mathrm{H}, \mathrm{H}-12), 4.60(\mathrm{t}, J=5.3 \mathrm{~Hz}, 2 \mathrm{H}, \mathrm{H}-10), 4.22(\mathrm{t}, J$ $=5.3 \mathrm{~Hz}, 2 \mathrm{H}, \mathrm{H}-17), 3.29(\mathrm{t}, J=5.3 \mathrm{~Hz}, 2 \mathrm{H}, \mathrm{H}-9), 2.72(\mathrm{t}, J=7.1 \mathrm{~Hz}, 2 \mathrm{H}, \mathrm{H}-5), 2.43$ (app. $q, J=$ $5.9 \mathrm{~Hz}, 2 \mathrm{H}, \mathrm{H}-16), 2.28(\mathrm{t}, J=7.5 \mathrm{~Hz}, 2 \mathrm{H}, \mathrm{H}-2), 1.75-1.69(\mathrm{~m}, 2 \mathrm{H}, \mathrm{H}-4), 1.59-1.51(\mathrm{~m}, 2 \mathrm{H}, \mathrm{H}-3)$. ${ }^{13} \mathrm{C}$ NMR (125 MHz, CDCl $)$ : $\delta 173.4$ (C-1), 166.2 (C-11), 165.5 (C-8), 156.7 (C-6), 144.4 (C-13), 140.3 (C-15), 129.4 (C-14), 116.3 (C-12), 113.1 (C-7), 62.2 (C-10), 61.9 (C17), 34.5 (C-2), 33.4 (C9), 32.7 (C-16), 30.7 (C-5), 28.2 (C-4), 24.1 (C-3). IR: (neat) cm' $1724(C=O), 1642(C=C), 1313$ (C-O). HRMS-ESI (m/z): [M + H] $]^{+}$calculated for $\mathrm{C}_{17} \mathrm{H}_{22} \mathrm{NO}_{4} \mathrm{~S}^{+}, 336.1264$; found 336.1256. 


\subsubsection{Synthesis of Amide 148}

Preparation of ( \pm )-3-Hydroxy-4-((1-phenyl-1H-tetrazol-5-yl)thio)butanenitrile (146)

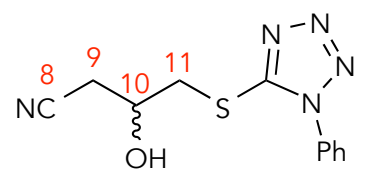

146

To a solution of 3-butenenitrile $(1.00 \mathrm{~mL}, 12.43 \mathrm{mmol})$ in $\mathrm{DCM}(50 \mathrm{~mL})$ was added $\mathrm{mCPBA}$ $(6.18 \mathrm{~g}, 25.08 \mathrm{mmol})$ in three portions on three separate days, and stirred for a total of seven days, after which the reaction mixture was washed with sat. aq. $\mathrm{NaHSO}_{3}(30 \mathrm{~mL} \times 3)$, sat. aq. $\mathrm{Na}_{2} \mathrm{CO}_{3}(30 \mathrm{~mL} \times 3)$, sat. aq. $\mathrm{NaHCO}_{3}(30 \mathrm{~mL})$, sat. aq. $\mathrm{NaCl}(30 \mathrm{~mL})$, dried with $\mathrm{MgSO}_{4}$, filtered and concentrated in vacuo to afford the desired epoxide with SM impurities $(0.73 \mathrm{~g})$ of sufficient purity to continue onto the next reaction. To a solution of the epoxide in DCM $(50 \mathrm{~mL})$ was added $4 \AA$ molecular sieves and stirred under $\mathrm{N}_{2}$ overnight. Mercaptophenyltetrazole $113(1.10 \mathrm{~g}, 6.2 \mathrm{mmol})$ was added, and stirred overnight at room temperature. The molecular sieves were filtered off, and the reaction mixture was washed with sat. aq. $\mathrm{NaHCO}_{3}(30 \mathrm{~mL} \times 3)$, sat. aq. $\mathrm{NaCl}(30 \mathrm{~mL})$, dried with $\mathrm{MgSO}_{4}$, filtered and concentrated in vacuo to afford the desired product $(1.01 \mathrm{~g}, 3.85 \mathrm{mmol}, 31 \%$ over 2 steps) as a white solid. Rf: 0.27 (1:1 PE:EtOAc). Melting point: 64.0-65.5 ${ }^{\circ} \mathrm{C} .{ }^{1} \mathrm{H}$ NMR $(500 \mathrm{MHz}$, $\left.\mathrm{CDCl}_{3}\right): \delta$ 7.60-7.59 (m, 5H, CH arom.), 4.51-4.50 (m, 1H, H-10), $4.33(\mathrm{~d}, J=4.5 \mathrm{~Hz}, 1 \mathrm{H}, \mathrm{OH})$, $3.66(\mathrm{dd}, J=14.7,3.4 \mathrm{~Hz}, 1 \mathrm{H}, \mathrm{H}-11), 3.52(\mathrm{dd}, J=14.7,6.8 \mathrm{~Hz}, 1 \mathrm{H}, \mathrm{H}-11), 2.81-2.72(\mathrm{~m}, 2 \mathrm{H}, \mathrm{H}-$ 9). ${ }^{13} \mathrm{C}$ NMR (125 MHz, $\left.\mathrm{CDCl}_{3}\right): \delta 154.0(\mathrm{~N}-(\mathrm{S}-) \mathrm{C}=\mathrm{N}), 133.2$ (C arom.), 130.6 ( $\mathrm{CH}$ arom.), 130.0 (CH arom.), 123.8 (CH arom.), 116.7 (C-8), 67.0 (C-10), 38.6 (C-11), 24.9 (C-9). IR (neat) cm-1: $3406(\mathrm{O}-\mathrm{H}), 2255(\mathrm{C} \equiv \mathrm{N})$. HRMS-ESI $(\mathrm{m} / \mathrm{z}):[\mathrm{M}+\mathrm{H}]^{+}$calculated for $\mathrm{C}_{11} \mathrm{H}_{12} \mathrm{~N}_{5} \mathrm{OS}^{+}, 262.0757$; found 262.0747 . 
Preparation of ( \pm )-3-((tert-Butyldiphenylsilyl)oxy)-4-((1-phenyl-1H-tetrazol-5yl)thio)butanenitrile (147)

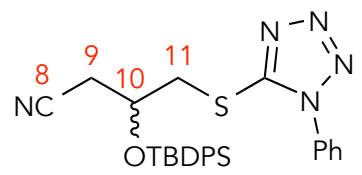

147

To a solution of alcohol $146(0.29 \mathrm{~g}, 1.11 \mathrm{mmol})$ in $\mathrm{DCM}(15 \mathrm{~mL})$ at $0{ }^{\circ} \mathrm{C}$ was added molecular sieves and imidazole $(0.28 \mathrm{~g}, 4.07 \mathrm{mmol})$ and stirred for 5 minutes. TBDPSCl $(0.90 \mathrm{~mL}$, $3.33 \mathrm{mmol})$ was added over 2 minutes, followed by TBAI $(0.02 \mathrm{~g}, 0.06 \mathrm{mmol})$, and the reaction mixture was left to warm to room temperature overnight. The reaction mixture was quenched with sat. aq. $\mathrm{NH}_{4} \mathrm{Cl}(10 \mathrm{~mL})$ and extracted with $\mathrm{DCM}(10 \mathrm{~mL} \times 3)$. The organic fractions were then washed with $\mathrm{H}_{2} \mathrm{O}(10 \mathrm{~mL})$, and sat. aq. $\mathrm{NaCl}(10 \mathrm{~mL})$, dried with $\mathrm{MgSO}_{4}$, filtered and concentrated in vacuo. The crude product was purified via gradient silica gel flash column chromatography (9:1 PE:EtOAc - 5:1 PE:EtOAc) to afford the desired product $(0.53 \mathrm{~g}$, $1.06 \mathrm{mmol}, 97 \%)$ as a colourless oil. $\mathrm{R}_{\mathrm{f}}$ : 0.73 (1:1 PE:EtOAc). ${ }^{1} \mathrm{H}$ NMR $\left(500 \mathrm{MHz}, \mathrm{CDCl}_{3}\right): \delta$ 7.68-7.65 (m, 4H, CH arom.), 7.58-7.55 (m, 3H, CH arom.), 7.48-7.32 (m, 8H, $\mathrm{CH}$ arom.), 4.45$4.42(\mathrm{~m}, 1 \mathrm{H}, \mathrm{H}-10), 3.61$ (dd, $J=14.1,6.3 \mathrm{~Hz}, 1 \mathrm{H}, \mathrm{H}-11), 3.54$ (dd, $J=13.9,5.3 \mathrm{~Hz}, 1 \mathrm{H}, \mathrm{H}-11$ ), $2.61(\mathrm{dd}, J=17.1,2.7 \mathrm{~Hz}, 1 \mathrm{H}, \mathrm{H}-9), 2.54(\mathrm{dd}, J=17.0,5.1 \mathrm{~Hz}, 1 \mathrm{H}, \mathrm{H}-9), 1.09\left(\mathrm{~s}, 9 \mathrm{H}, \mathrm{CH}_{3}, \mathrm{tBu}\right.$ ). ${ }^{13} \mathrm{C}$ NMR (125 MHz, $\left.\mathrm{CDCl}_{3}\right): \delta 153.2(\mathrm{~N}-(\mathrm{S}-) \mathrm{C}=\mathrm{N}), 135.8$ (CH arom.), 133.4 (C arom.), 132.3 (C arom.), 130.3 ( $\mathrm{CH}$ arom.), 130.2 ( $\mathrm{CH}$ arom.), 129.9 ( $\mathrm{CH}$ arom.), 128.0 ( $\mathrm{CH}$ arom.), 123.5 ( $\mathrm{CH}$ arom.), 116.5 (C-8), 66.9 (C-10), 38.5 (C-11), 26.8 ( $\left.\mathrm{CH}_{3} \mathrm{tBu}\right), 25.8$ (C-9), 19.3 (C tBu). IR (neat) $\mathrm{cm}^{-1}: 2958(\mathrm{C}-\mathrm{H}), 2250(\mathrm{C} \equiv \mathrm{N}), 1596(\mathrm{C}=\mathrm{C})$. HRMS-ESI $(\mathrm{m} / \mathrm{z}):[\mathrm{M}+\mathrm{H}]^{+}$calculated for $\mathrm{C}_{27} \mathrm{H}_{30} \mathrm{~N}_{5} \mathrm{OSSi}^{+}, 500.1935$; found 500.1955 .

Preparation of ( \pm )-3-((tert-Butyldiphenylsilyl)oxy)-4-((1-phenyl-1H-tetrazol-5yl)thio)butanamide (148)

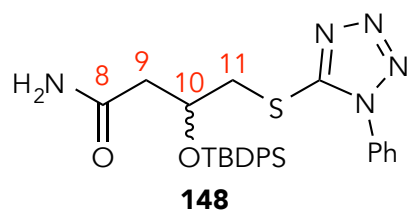

To a solution of nitrile $147(0.52 \mathrm{~g}, 1.03 \mathrm{mmol})$ in DMSO $(10 \mathrm{~mL})$ at $0{ }^{\circ} \mathrm{C}$ was added $\mathrm{K}_{2} \mathrm{CO}_{3}$ (60.0 mg, $0.4 \mathrm{mmol}) . \mathrm{H}_{2} \mathrm{O}_{2}(2 \mathrm{~mL}, 20 \mathrm{mmol})$ was then added dropwise over 30 minutes. The 
mixture was the allowed to warm to room temperature overnight, and then heated at $35^{\circ} \mathrm{C}$ for 7.5 hours. The reaction mixture was then quenched with $\mathrm{H}_{2} \mathrm{O}(10 \mathrm{~mL})$ and a white precipitate was observed. The reaction mixture was extracted with EtOAc $(15 \mathrm{~mL} \times 3)$, washed with sat. aq. $\mathrm{NaCl}(15 \mathrm{~mL})$, dried over $\mathrm{MgSO}_{4}$, filtered and concentrated in vacuo. The product was then purified via gradient silica gel flash column chromatography (5:1 PE:EtOAc - EtOAc) to provide the desired amide $(0.48 \mathrm{~g}, 0.92 \mathrm{mmol}, 89 \%)$ as a white crystalline solid. $\mathrm{R}_{\mathrm{f}}$ : 0.67 (EtOAc). Melting point: $74.0-76.1{ }^{\circ} \mathrm{C} .{ }^{1} \mathrm{H}$ NMR $\left(500 \mathrm{MHz} \mathrm{CDCl}_{3}\right): \delta 7.67-7.63(\mathrm{~m}, 4 \mathrm{H}, \mathrm{CH}$ arom.), 7.55-7.54 (m, 3H, $\mathrm{CH}$ arom.), 7.49-7.47 (m, 2H, CH arom.), 7.43-7.40 (m, 2H, $\mathrm{CH}$ arom.), 7.36$7.32(\mathrm{~m}, 4 \mathrm{H}, \mathrm{CH}$ arom.), 6.15 (bs, 1H, NH), 5.44 (bs, 1H, NH), 4.57 (quin, $J=5.6 \mathrm{~Hz}, 1 \mathrm{H}, \mathrm{H}-10$ ), $3.60(\mathrm{dd}, J=13.8,5.0 \mathrm{~Hz}, 1 \mathrm{H}, \mathrm{H}-11), 3.54(\mathrm{dd}, J=13.7,6.0 \mathrm{~Hz}, 1 \mathrm{H}, \mathrm{H}-11), 2.60-2.52(\mathrm{~m}, 2 \mathrm{H}, \mathrm{H}-$ 9), 1.06 (s, 9H, $\left.\mathrm{CH}_{3} \mathrm{tBu}\right) .{ }^{13} \mathrm{C} \mathrm{NMR}\left(125 \mathrm{MHz}, \mathrm{CDCl}_{3}\right): \delta 171.8$ (C-8), $154.1(\mathrm{~N}-(\mathrm{S}-) \mathrm{C}=\mathrm{N}), 135.8$ ( $\mathrm{CH}$ arom.), 133.5 (C arom.), 132.8 (C arom.), 130.1 (CH arom.), 130.0 (CH arom.), 129.8 (CH arom.), 127.7 ( $\mathrm{CH}$ arom.), 123.6 ( $\mathrm{CH}$ arom.), 68.5 (C-10), 42.7 (C-9), 39.2 (C-11), $26.9\left(\mathrm{CH}_{3} \mathrm{tBu}\right)$, 19.3 (C tBu). IR (neat) cm $\mathrm{cm}^{-1}: 3420(\mathrm{~N}-\mathrm{H}), 1738(\mathrm{C}=\mathrm{O}), 1500(\mathrm{~N}-\mathrm{H})$. HRMS-ESI $(\mathrm{m} / \mathrm{z}):[\mathrm{M}+\mathrm{H}]^{+}$ calculated for $\mathrm{C}_{27} \mathrm{H}_{32} \mathrm{~N}_{5} \mathrm{O}_{2} \mathrm{SSi}^{+}, 518.2040$; found 518.2035.

\subsection{Experimental for Biological Testing}

\subsubsection{Cell Culture}

The $1 \mathrm{~A} 9$ cell line was cultured at $37{ }^{\circ} \mathrm{C}$ in an atmosphere of $5 \% \mathrm{CO}_{2}$ (Sanyo Electric Company). Cells were harvested at approximately $75-80 \%$ confluence, and cultured in a laminar flow hood using standard cell culture techniques. ${ }^{73}$

1A9 cells were cultured in a T25 flask (Falcon) with growth medium containing RPMI-1640 supplemented with 10\% fetal bovine serum (GE Healthcare), 1\% penicillin/streptomycin (Life Technologies) and $0.1 \%$ insulin (Sigma-Aldrich). Growth media was removed from flask and cells were rinsed with trypLE ${ }^{\mathrm{TM}}$ select (1X) $(500 \mu \mathrm{L})$ (Life Technologies). Cells were detached from the flask using trypLE ${ }^{\mathrm{TM}}$ select $(1 \mathrm{X})(500 \mu \mathrm{L})$ and incubated for 3 minutes. The cells were then suspended in fresh growth media and centrifuged for 3 minutes at 300 RCF. The supernatant was removed, cells were re-suspended in growth media, and from this $1 / 10^{\text {th }}$ of the cells were seeded into a new culture vessel with growth media $(7 \mathrm{~mL})$. 


\subsubsection{MTT Assays}

Determination of the $I C_{50}$ of Analogue 130

$1 \mathrm{~A} 9$ cells were seeded into a 96-well plate (Corning) at a concentration of $1 \times 10^{5}$ cells/well and incubated over night. Cells were then treated to analogue 130 with a 2-fold serial dilution down the 96-well plate ( $1 \mathrm{mM}$ in $1 \%$ DMSO $-2 \mu \mathrm{M}$ in $0.002 \% \mathrm{DMSO}$ ) and incubated for 72 hours. MTT (20 $\mu \mathrm{L} ; 5 \mathrm{mg} / \mathrm{mL}$ in filtered PBS) was then added to each well, followed by incubation for 2 hours. The purple precipitates were then solubilised in MTT solubiliser (100 $\mu$;; $10 \% \mathrm{SDS}, 45 \% \mathrm{DMF}, \mathrm{pH} 4.5$ in $\mathrm{dd}_{2} \mathrm{O}$ ) and left over night in the incubator. The plate was then read at $570 \mathrm{~nm}$ in an automated multiwell plate reader (PerkinElmer). The cell number was calculated as a percentage of control (cells treated with only DMSO, $1 \%-0.002 \%$ ): $\%$ of control $=($ sample absorbance-blank/average control-blank $) \times 100$. Data was then plotted using SigmaPlot software.

\section{Competitive Bioactivity Assay Between Analogue 130 and Pateamine}

$1 \mathrm{~A} 9$ cells were seeded into a 96-well plate (Corning) at a concentration of $1 \times 10^{5}$ cells/well and incubated over night. Cells were then treated to analogue 130 (25 mM in 0.25\% DMSO) and incubated for 12 hours. After this, cells were treated with pateamine with a 2-fold serial dilution down the 96 well plate (50 nM in 0.1\% DMSO - $0.8 \mathrm{nM}$ in 0.002\% DMSO) and incubated for 58 hours. MTT ( $20 \mu \mathrm{L} ; 5 \mathrm{mg} / \mathrm{mL}$ in filtered PBS) was then added to each well, followed by incubation for 2 hours. The purple precipitates were then solubilised in MTT solubiliser (100 $\mu$; $10 \% \mathrm{SDS}, 45 \% \mathrm{DMF}, \mathrm{pH} 4.5$ in $\mathrm{dd}_{2} \mathrm{O}$ ) and left over night in the incubator. The plate was then read at $570 \mathrm{~nm}$ in an automated multiwell plate reader (PerkinElmer). The cell number was calculated as a percentage of control (cells treated with DMSO $0.1 \%)$ : \% of control $=($ sample absorbance-blank/average control-blank) $\times$ 100. Data was then plotted using SigmaPlot software. 


\section{NMR SPECTRA FOR NOVEL COMPOUNDS}
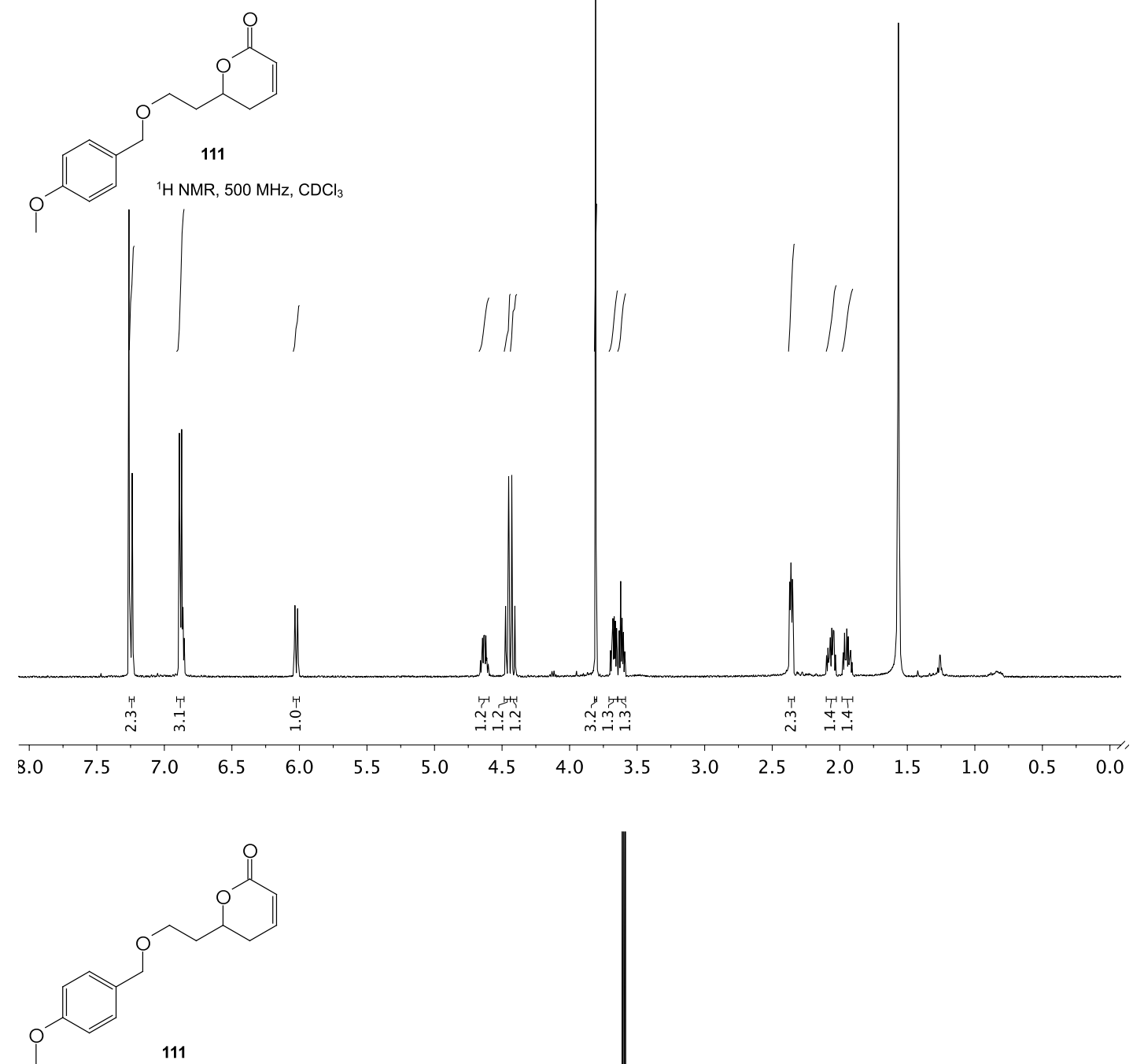

${ }^{13} \mathrm{C} \mathrm{NMR}, 125 \mathrm{MHz}, \mathrm{CDCl}_{3}$

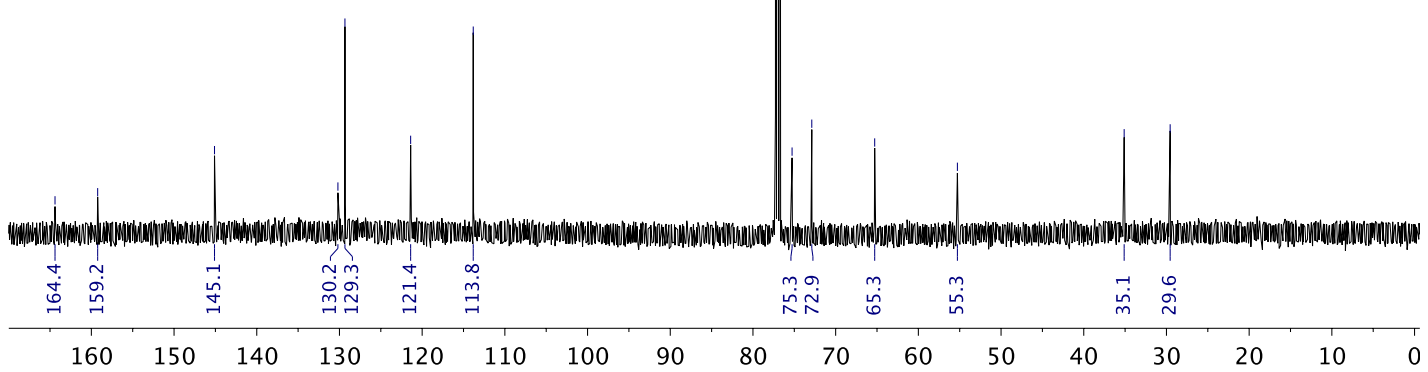




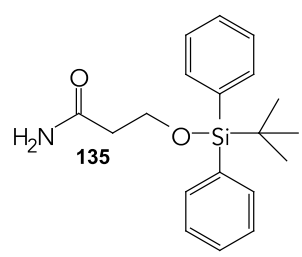

${ }^{1} \mathrm{H} \mathrm{NMR}, 500 \mathrm{MHz}, \mathrm{CDCl}_{3}$<smiles>CCCC</smiles>
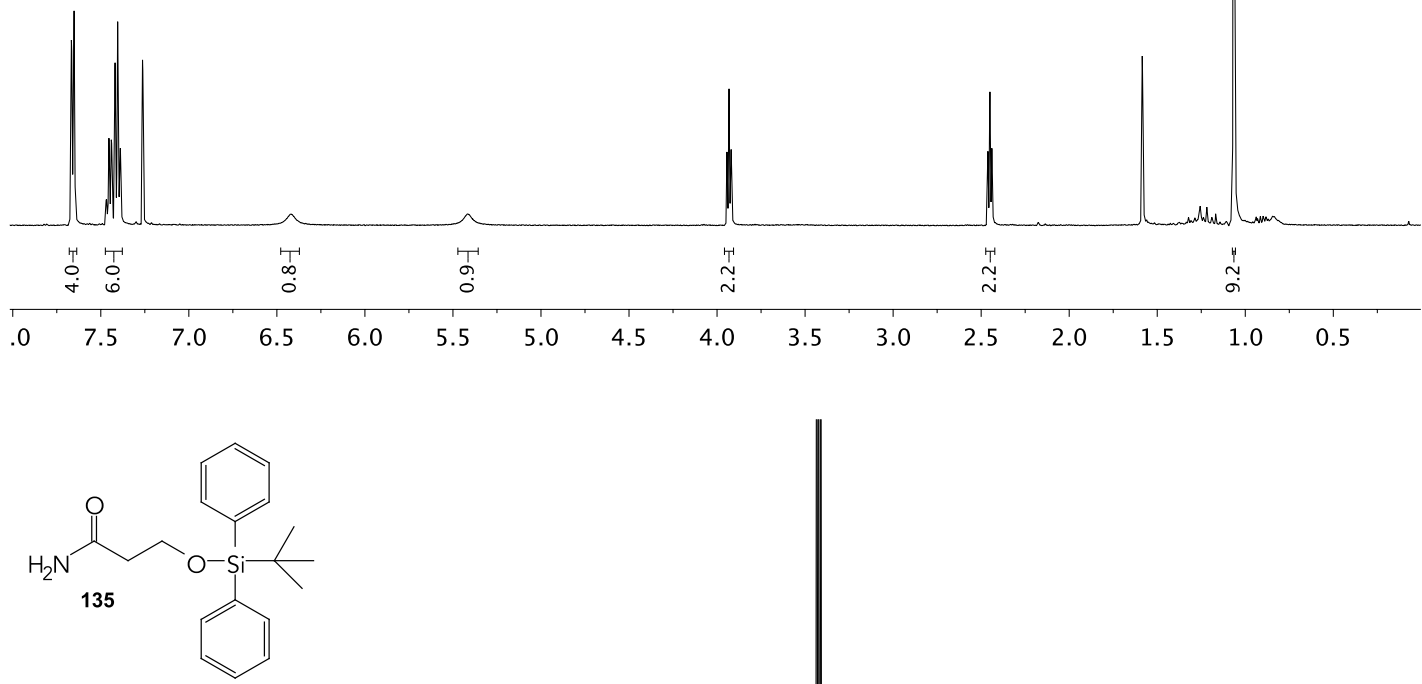

${ }^{13} \mathrm{C} \mathrm{NMR}, 125 \mathrm{MHz}, \mathrm{CDCl}_{3}$

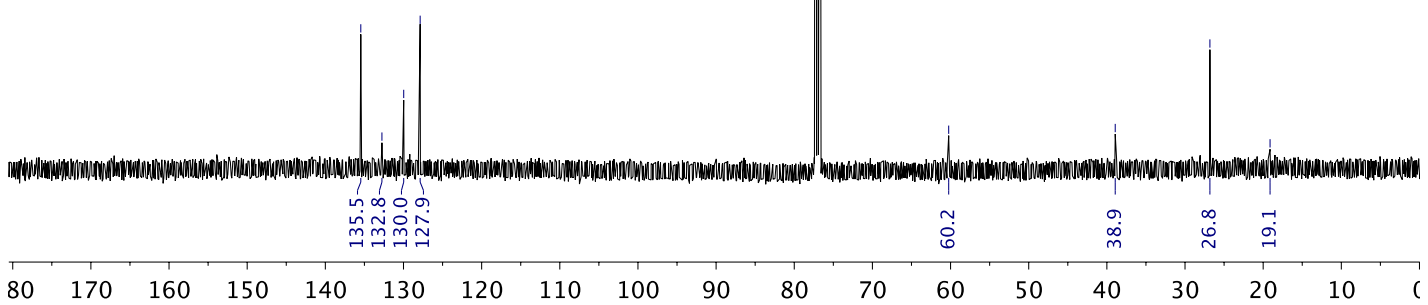




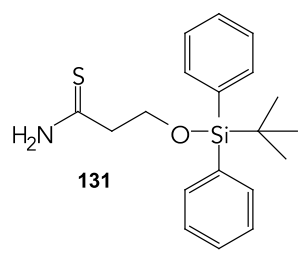

${ }^{1} \mathrm{H} \mathrm{NMR}, 500 \mathrm{MHz}, \mathrm{CDCl}_{3}$
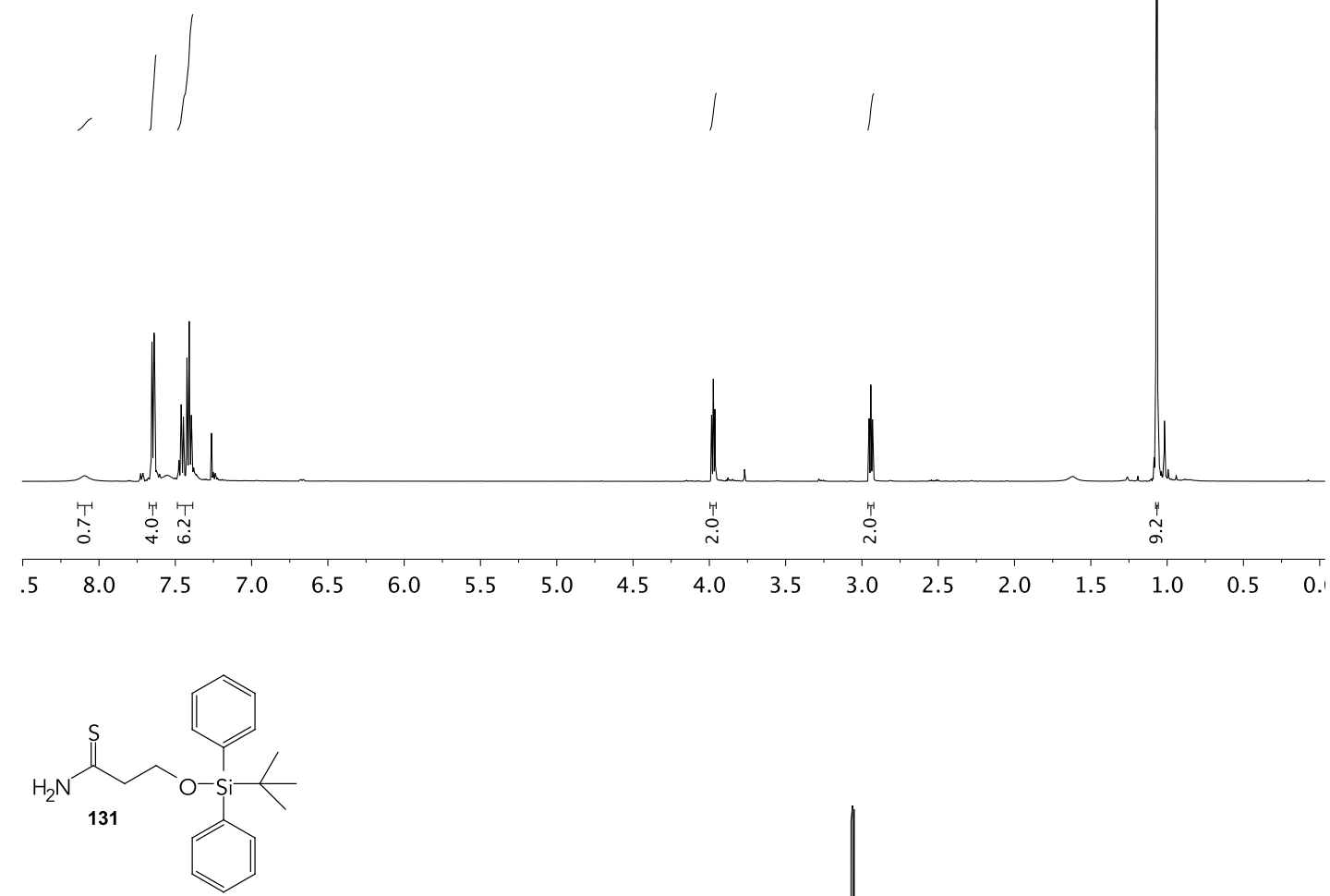

${ }^{13} \mathrm{C}$ NMR, $125 \mathrm{MHz}, \mathrm{CDCl}_{3}$

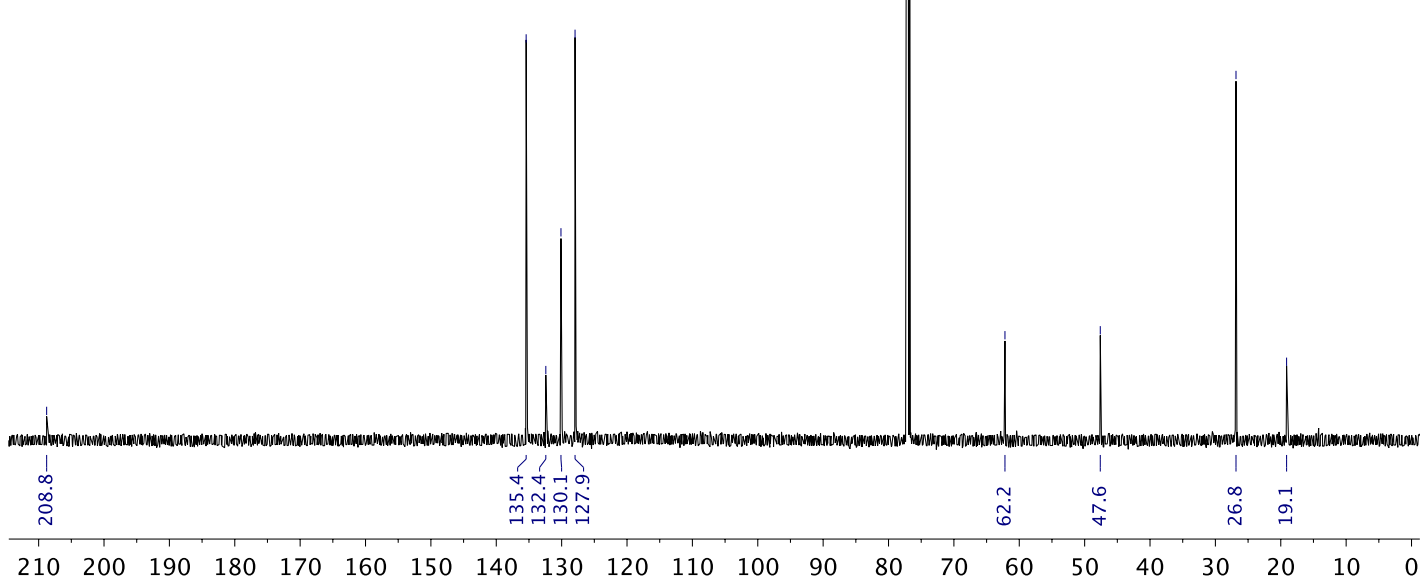




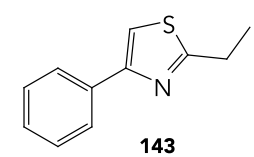

${ }^{1} \mathrm{H} \mathrm{NMR}, 500 \mathrm{MHz}, \mathrm{CDCl}_{3}$
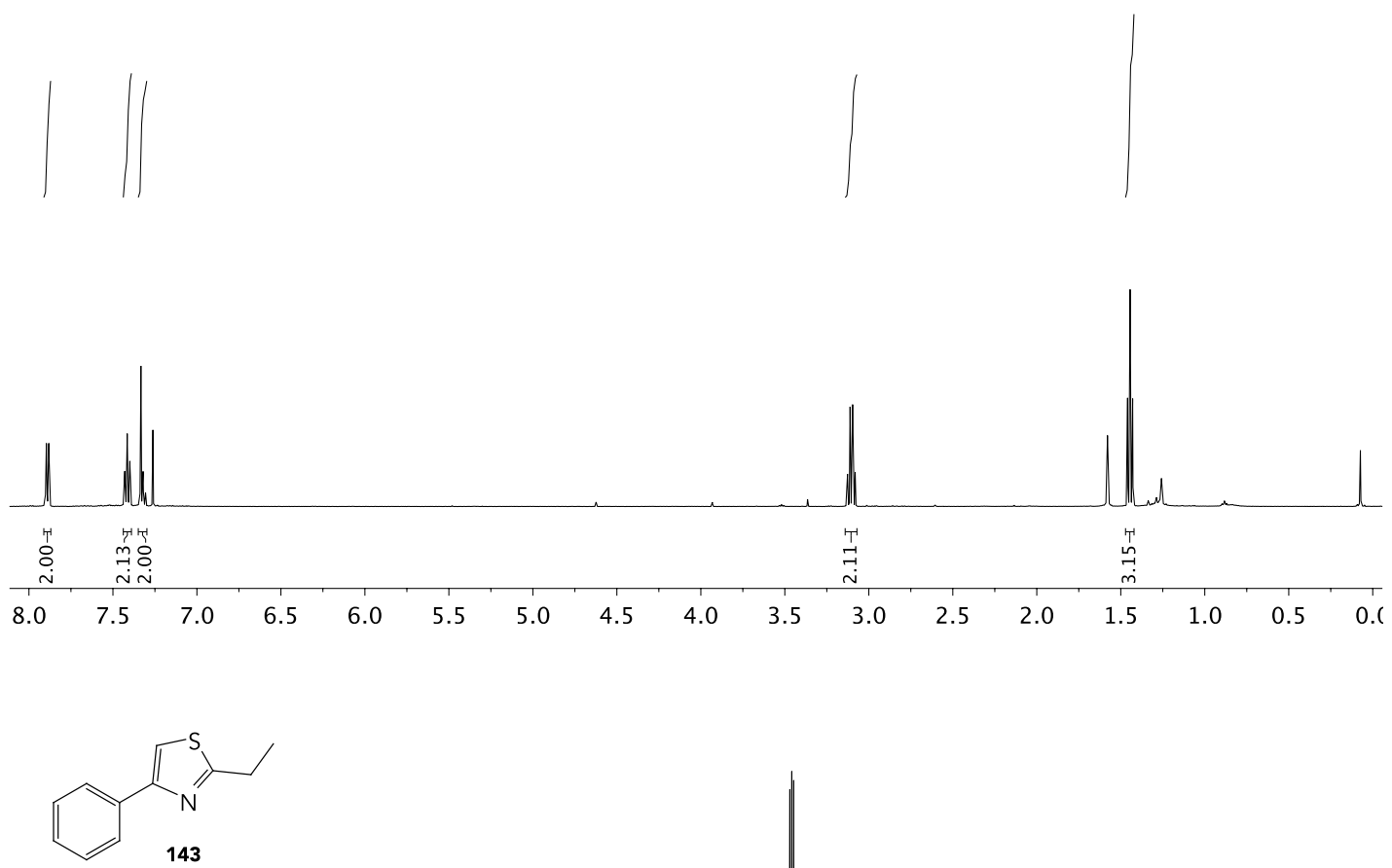

${ }^{13} \mathrm{C} \mathrm{NMR}, 125 \mathrm{MHz}, \mathrm{CDCl}_{3}$

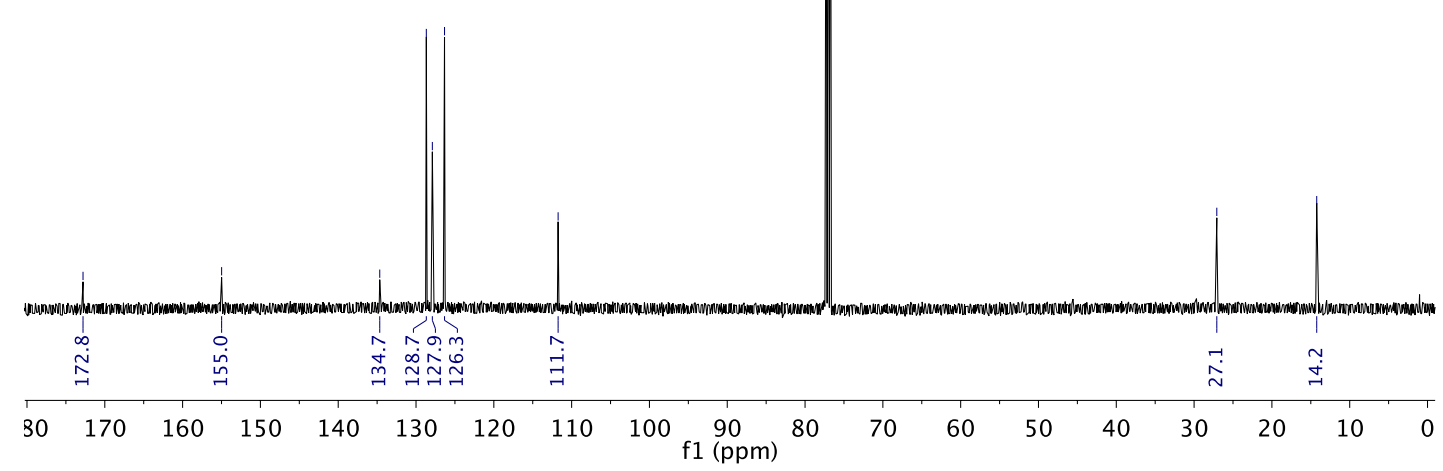



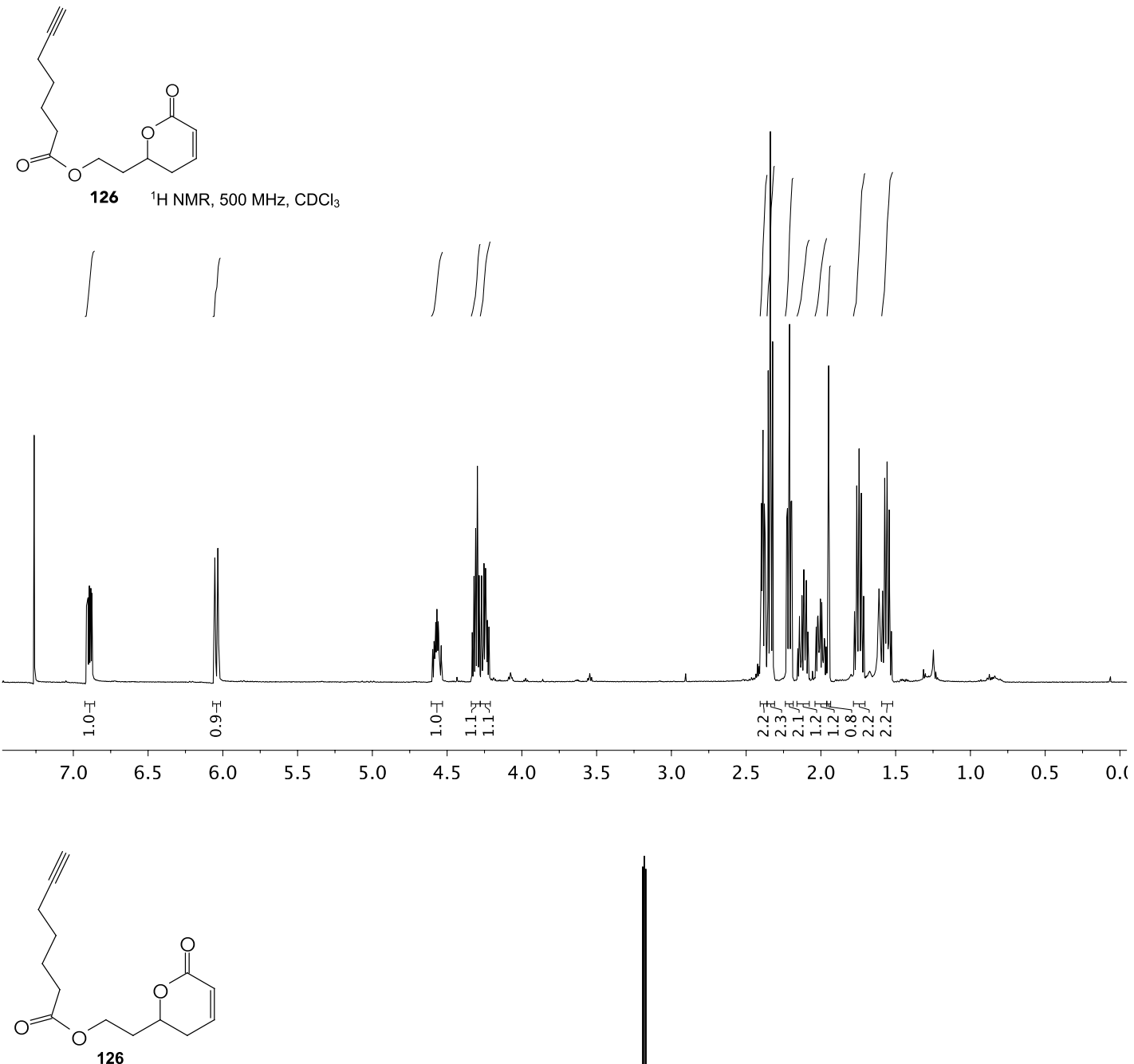

${ }^{13} \mathrm{C} \mathrm{NMR}, 125 \mathrm{MHz}, \mathrm{CDCl}_{3}$

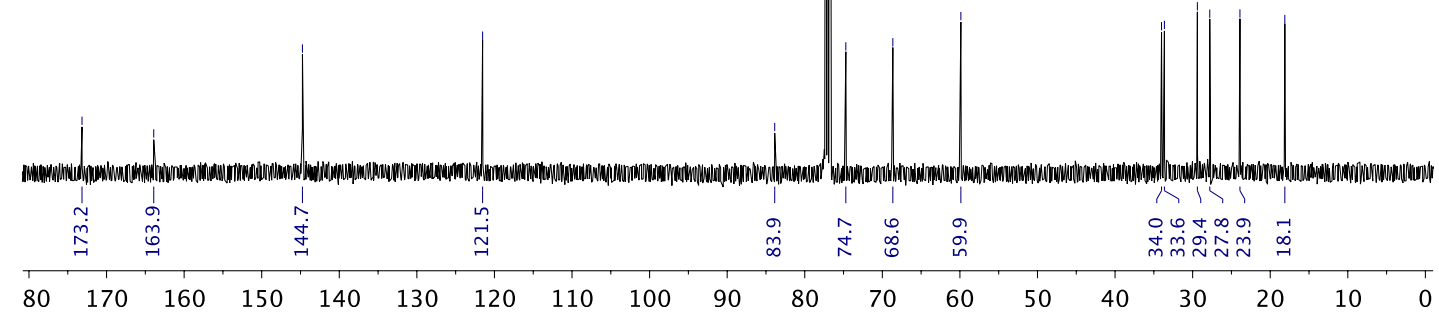



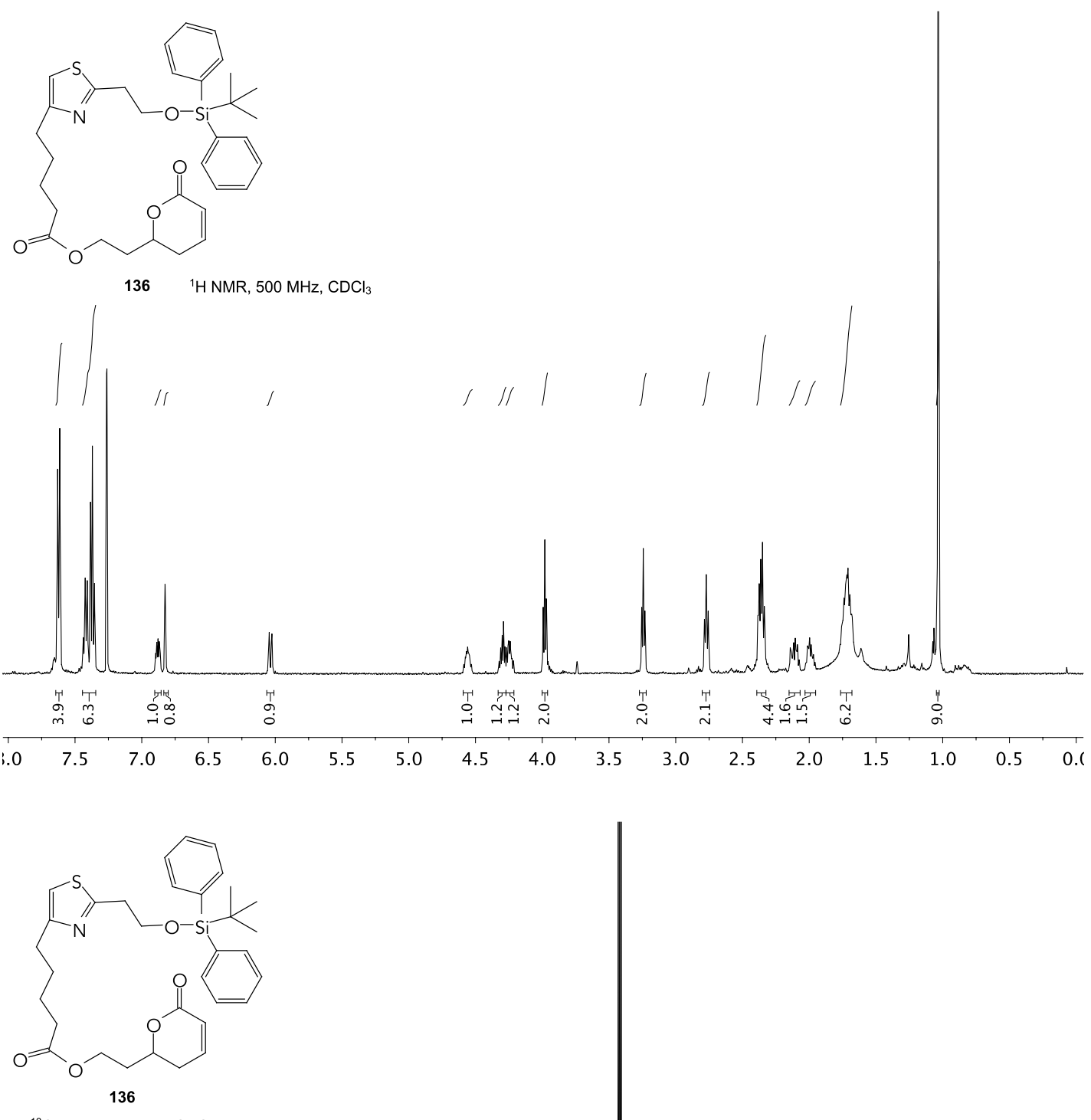

${ }^{13} \mathrm{C} \mathrm{NMR}, 125 \mathrm{MHz}, \mathrm{CDCl}_{3}$

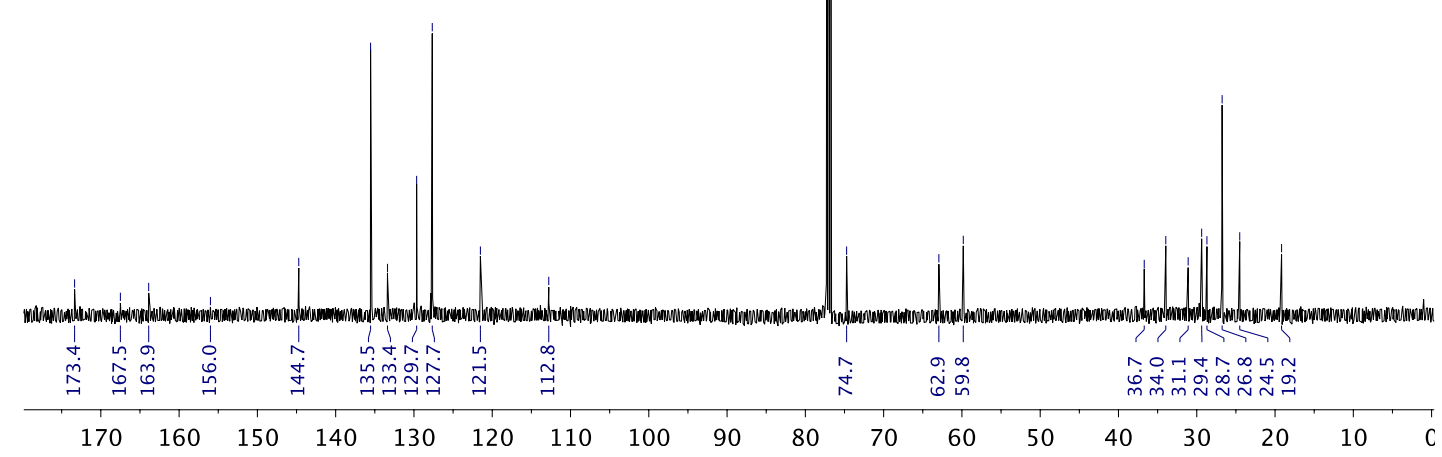



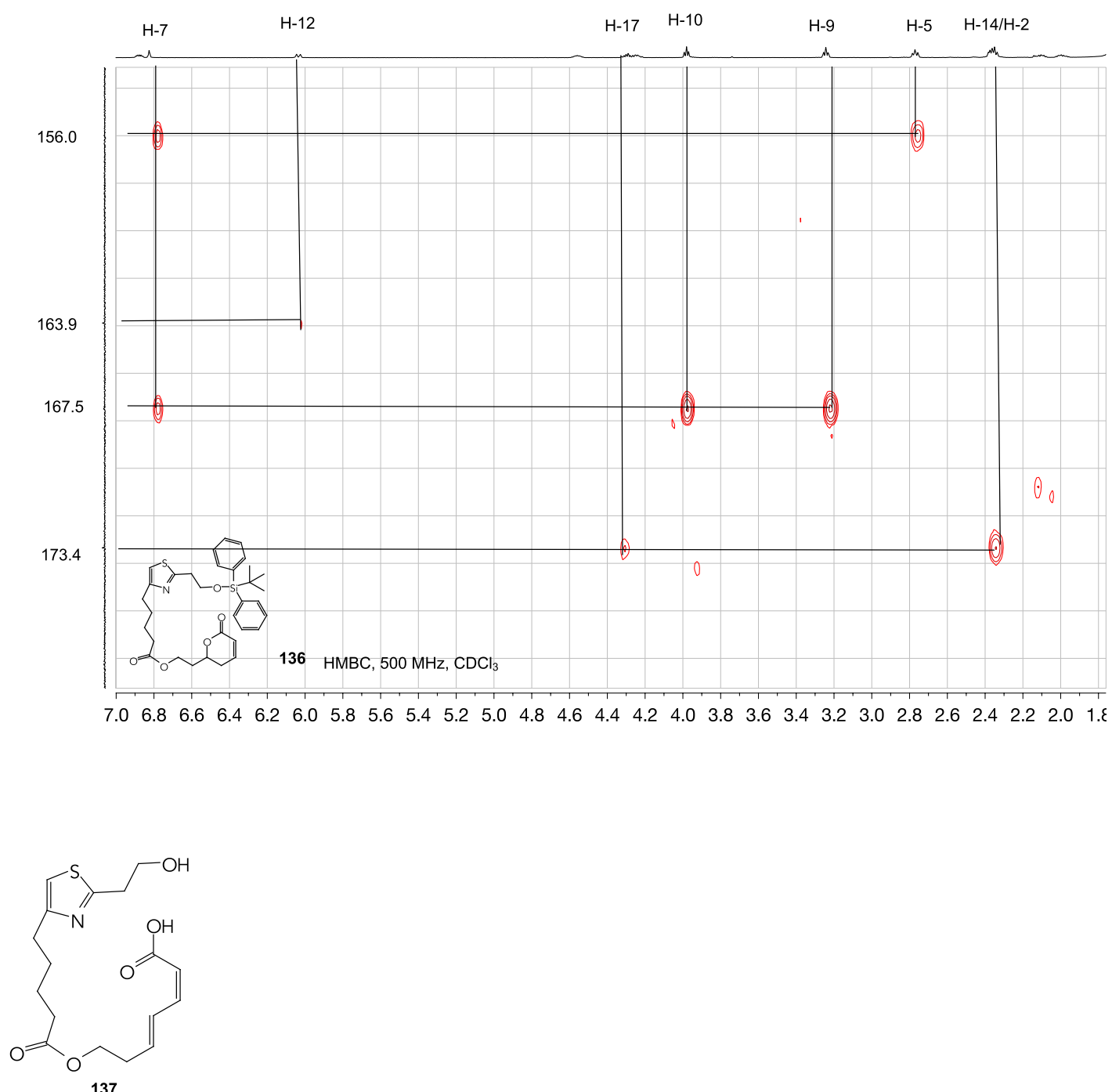

${ }^{1} \mathrm{H} \mathrm{NMR}, 500 \mathrm{MHz}, \mathrm{CDCl}_{3}$

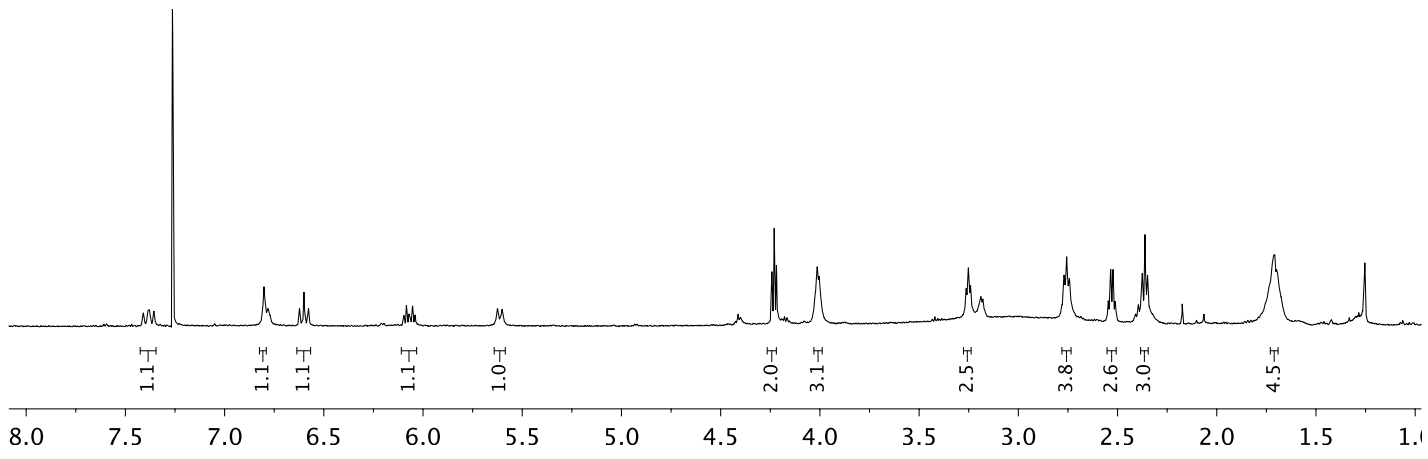




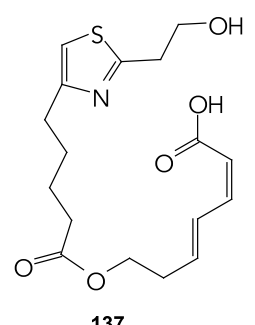

${ }^{13} \mathrm{C} \mathrm{NMR}, 125 \mathrm{MHz}, \mathrm{CDCl}_{3}$

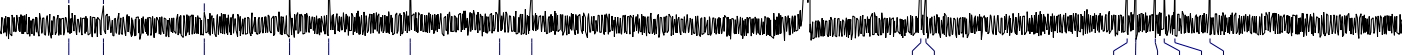

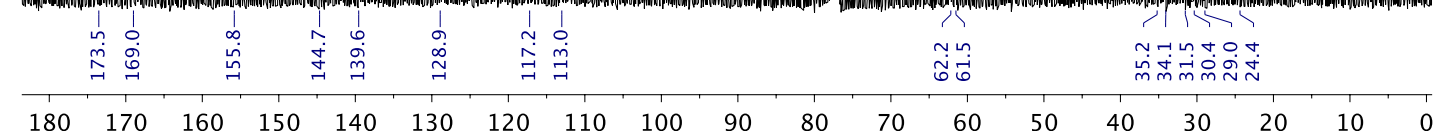

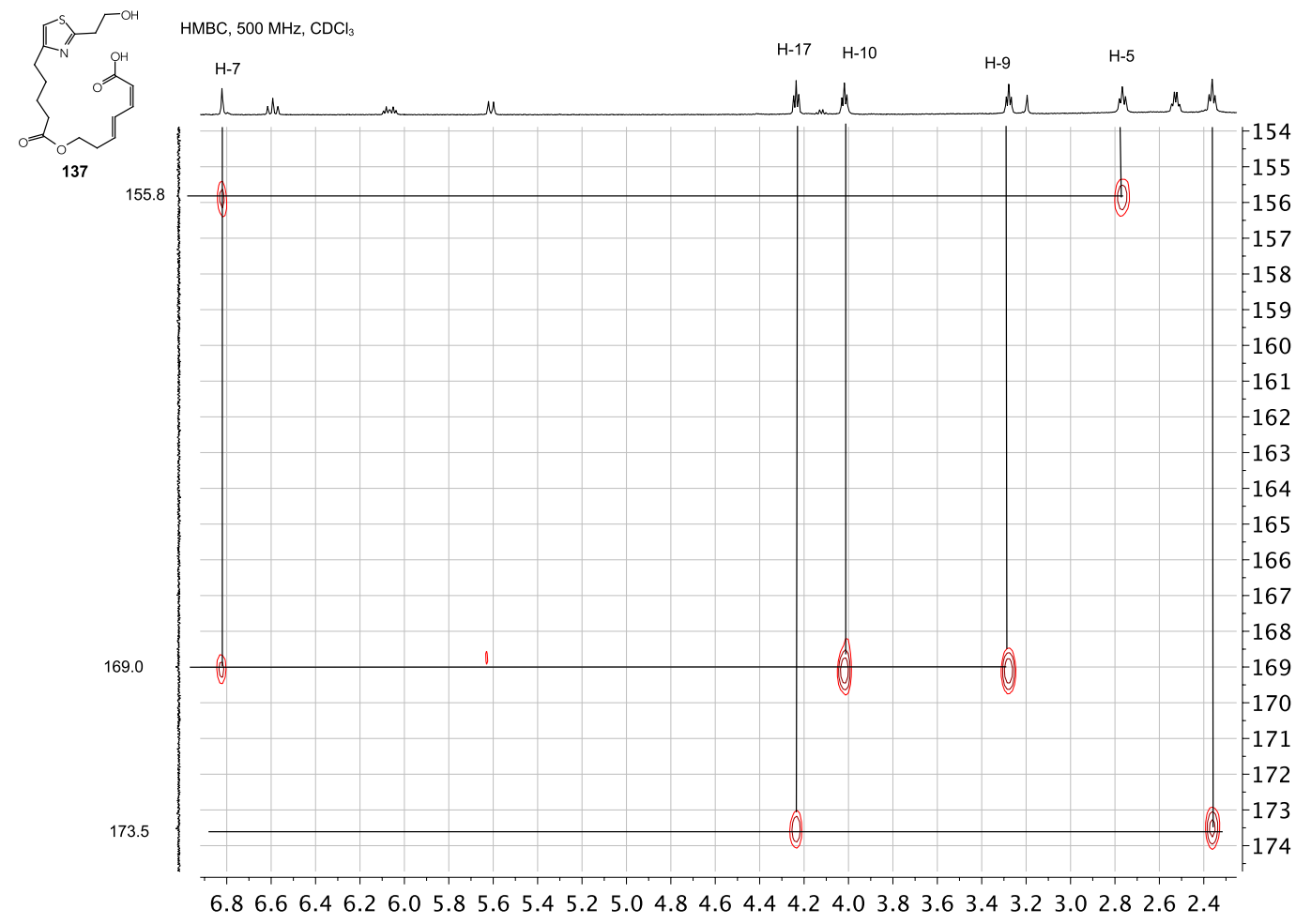




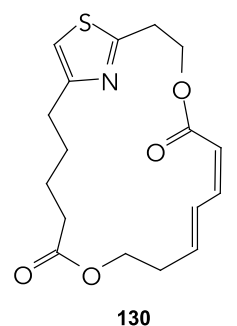

${ }^{1} \mathrm{H} \mathrm{NMR}, 500 \mathrm{MHz}, \mathrm{CDCl}_{3}$
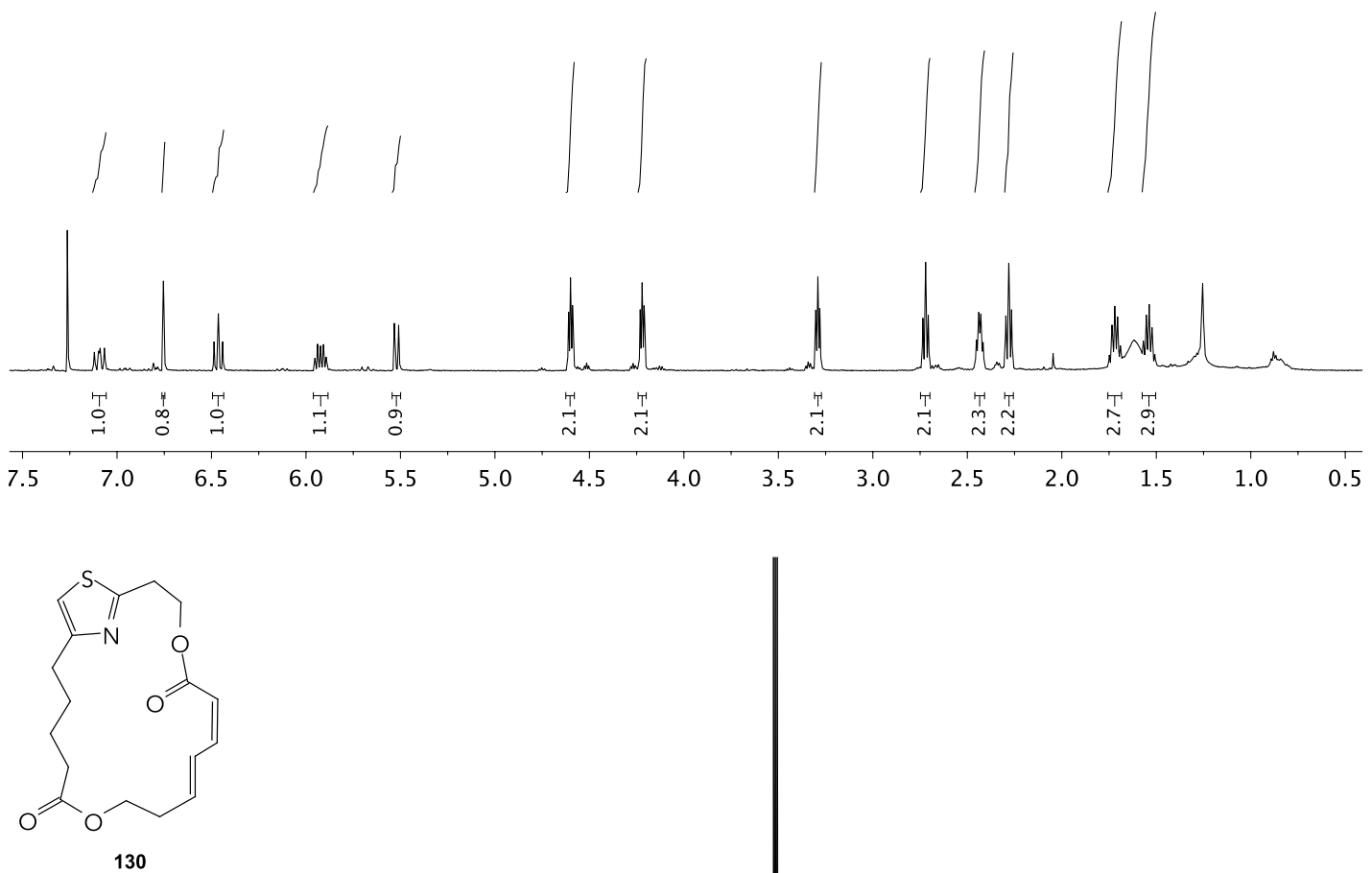

${ }^{13} \mathrm{C} \mathrm{NMR}, 125 \mathrm{MHz}, \mathrm{CDCl}_{3}$ 


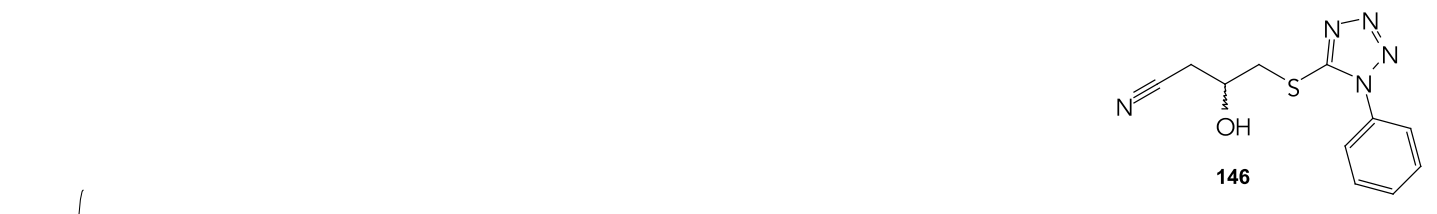

${ }^{1} \mathrm{H} \mathrm{NMR}, 500 \mathrm{MHz}, \mathrm{CDCl}_{3}$
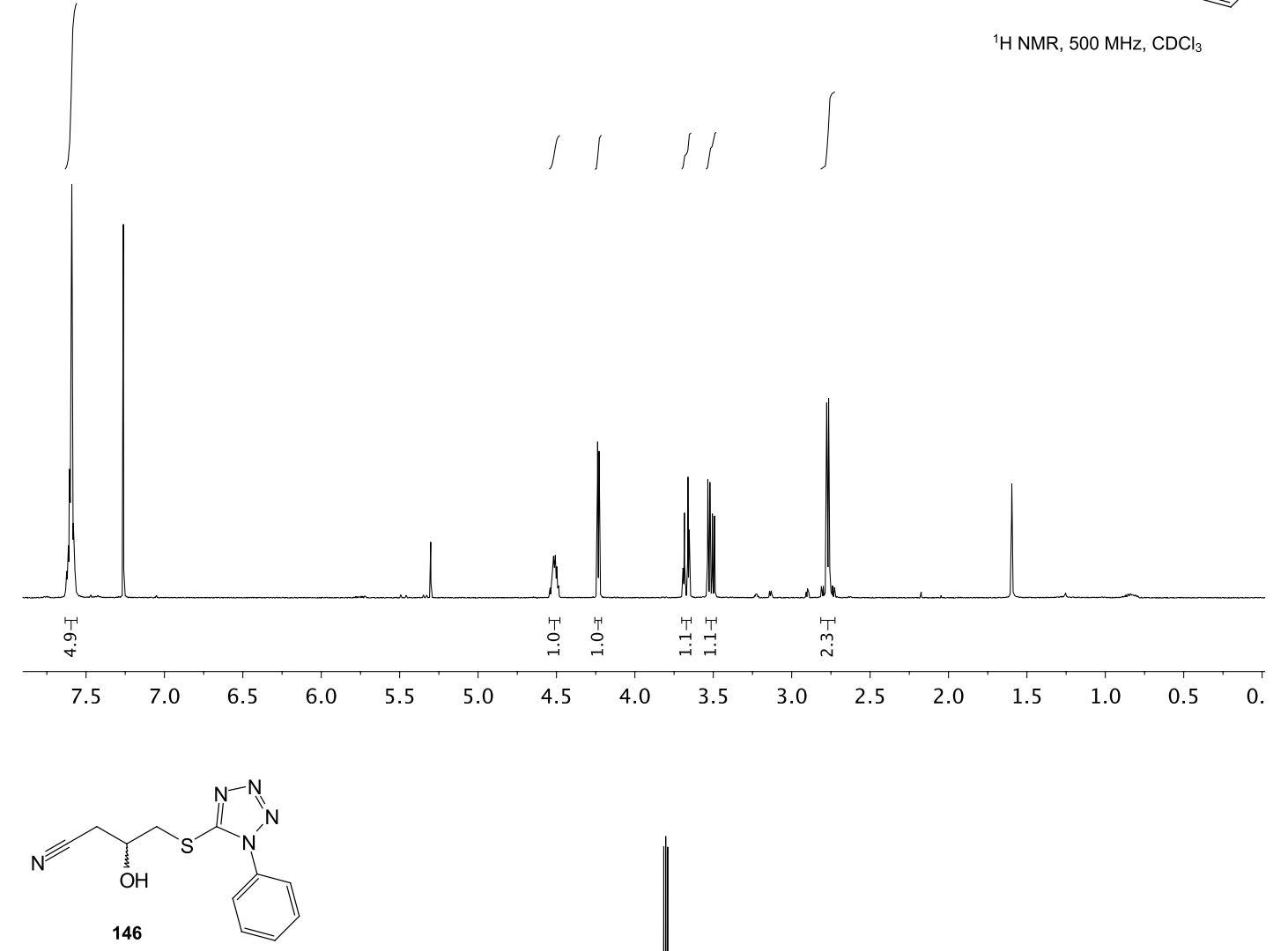

${ }^{13} \mathrm{C} \mathrm{NMR}, 125 \mathrm{MHz}, \mathrm{CDCl}_{3}$

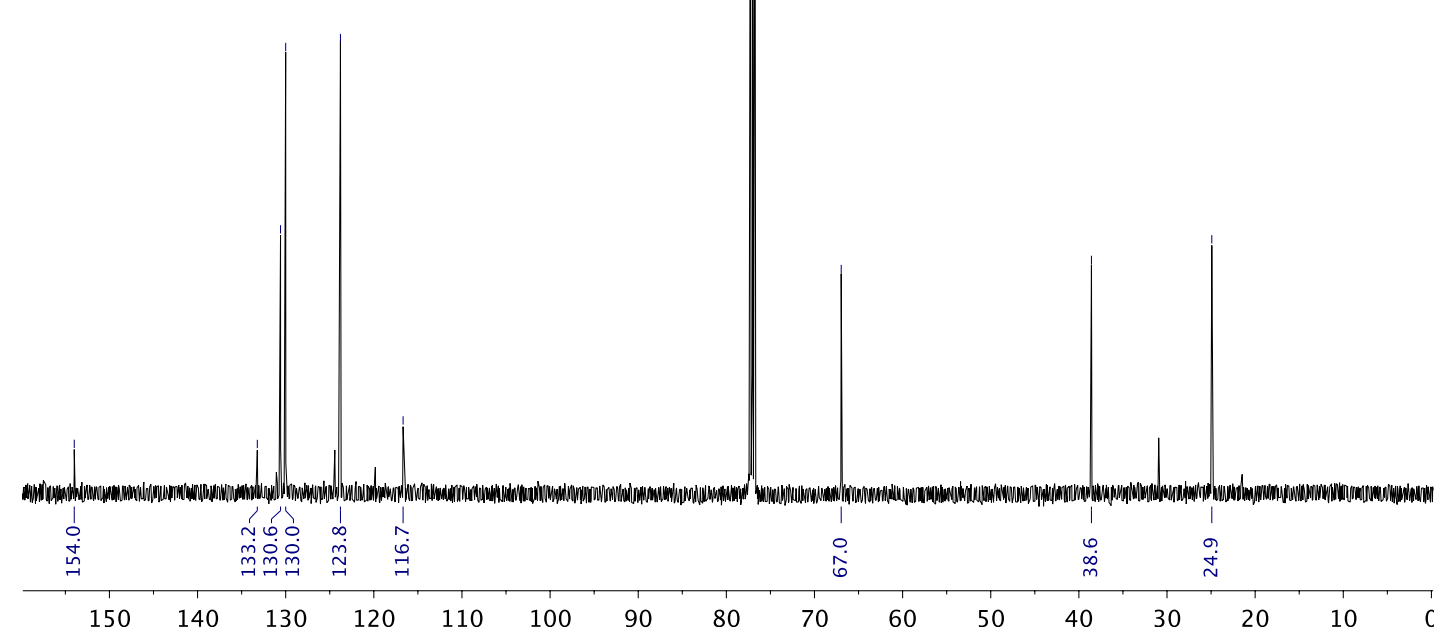




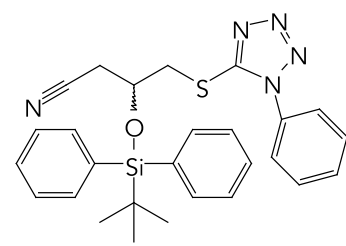

147

${ }^{1} \mathrm{H} \mathrm{NMR}, 500 \mathrm{MHz}, \mathrm{CDCl}_{3}$
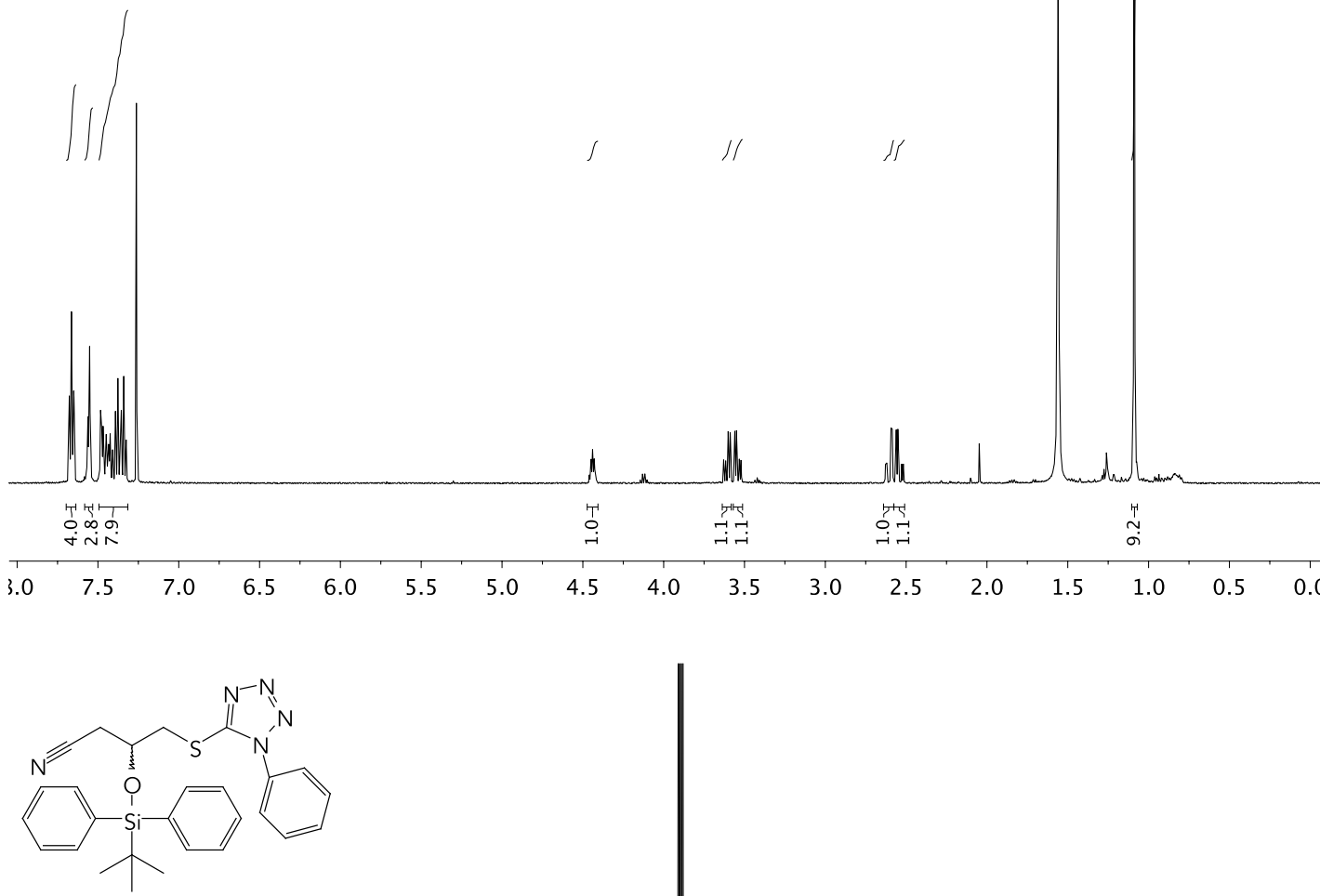

147

${ }^{13} \mathrm{C} \mathrm{NMR}, 125 \mathrm{MHz}, \mathrm{CDCl}_{3}$

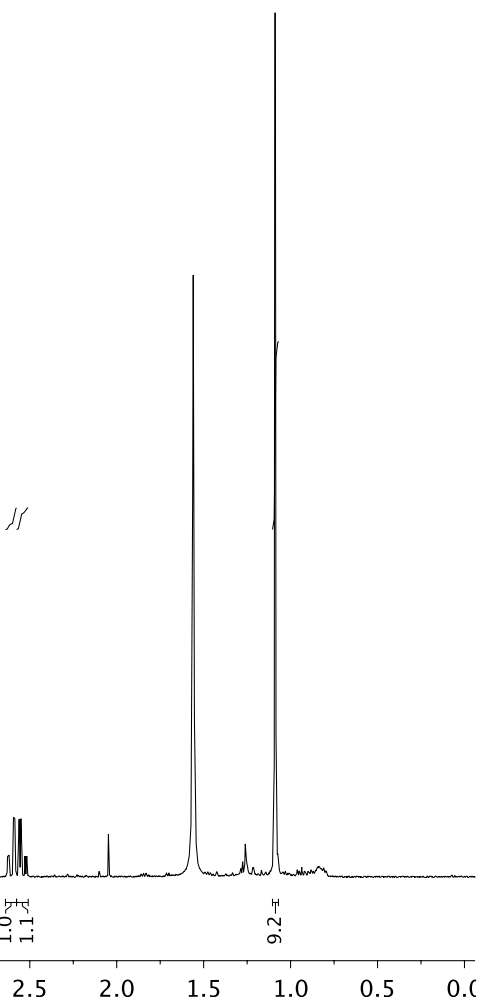

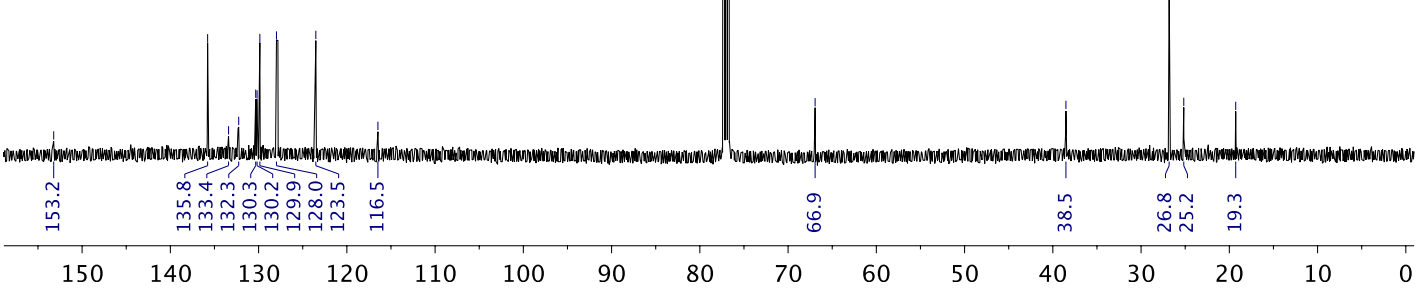




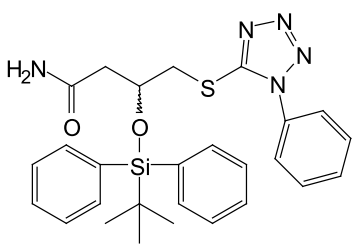

148

${ }^{1} \mathrm{H} \mathrm{NMR}, 500 \mathrm{MHz}, \mathrm{CDCl}_{3}$
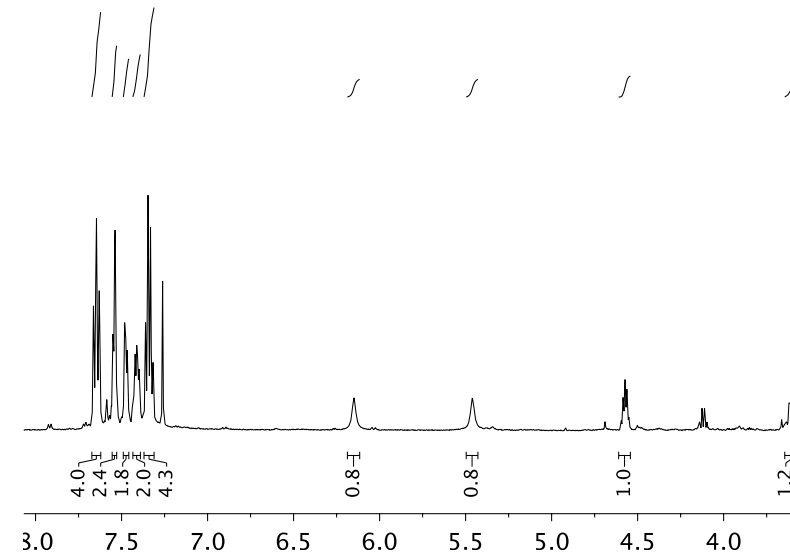

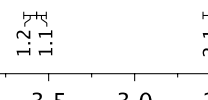

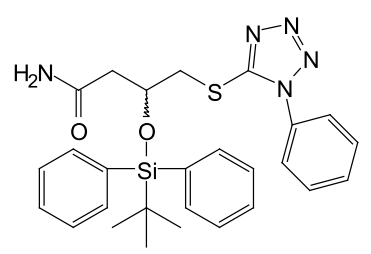

148

${ }^{13} \mathrm{C} \mathrm{NMR}, 125 \mathrm{MHz}, \mathrm{CDCl}_{3}$

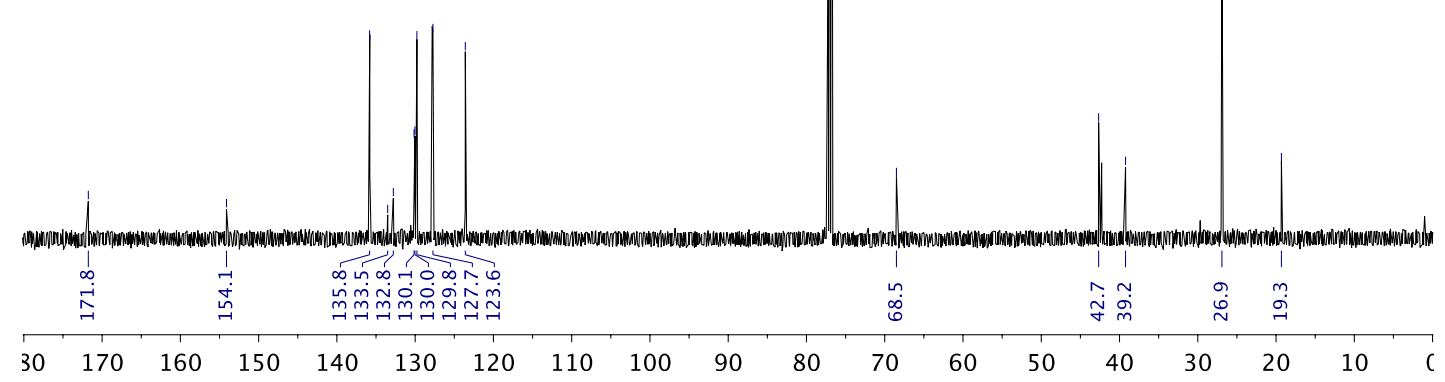




\section{CHAPTER SIX: REFERENCES}

1. Northcote, P. T.; Blunt, J. W.; Munro, M. H. G., Pateamine: a Potent Cytotoxin From the New Zealand Marine Sponge, Mycale sp. Tetrahedron Lett. 1991, 32 (44), 6411-6414.

2. Low, W.-K.; Li, J.; Zhu, M.; Kommaraju, S. S.; Shah-Mittal, J.; Hull, K.; Liu, J. O.; Romo, D., SecondGeneration Derivatives of the Eukaryotic Translation Initiation Inhibitor Pateamine A Targeting elF4A as Potential Anticancer Agents. Biorg. Med. Chem. 2014, 22 (1), 116-125.

3. Hanson, J. R., Natural Products: The Secondary Metabolites; The Royal Society of Chemistry: Cambridge, UK, 2003; Vol. 17; p 1-34.

4. Simmons, T. L.; Andrianasolo, E.; McPhail, K.; Flatt, P.; Gerwick, W. H., Marine Natural Products as Anticancer Drugs. Mol. Cancer Ther. 2005, 4 (2), 333-342.

5. Newman, D. J.; Cragg, G. M., Natural Products as Sources of New Drugs Over the 30 Years From 1981 to 2010. J. Nat. Prod. 2012, 75 (3), 311-335.

6. Newman, D. J.; Cragg, G. M., Marine Natural Products and Related Compounds in Clinical and Advanced Preclinical Trials. J. Nat. Prod. 2004, 67 (8), 1216-1238.

7. DeChristopher, B. A.; Fan, A. C.; Felsher, D. W.; Wender, P. A., "Picolog," a Synthetically-Available Bryostatin Analog, Inhibits Growth of MYC-Induced Lymphoma In Vivo. Oncotarget 2012, 3 (1), 58-66.

8. Wender, P. A.; Baryza, J. L.; Bennett, C. E.; Bi, F. C.; Brenner, S. E.; Clarke, M. O.; Horan, J. C.; Kan, C.; Lacôte, E.; Lippa, B.; Nell, P. G.; Turner, T. M., The Practical Synthesis of a Novel and Highly Potent Analogue of Bryostatin. J. Am. Chem. Soc. 2002, 124 (46), 13648-13649.

9. Keck, G. E.; Poudel, Y. B.; Cummins, T. J.; Rudra, A.; Covel, J. A., Total Synthesis of Bryostatin 1. J. Am. Chem. Soc. 2011, 133 (4), 744-747.

10. Rzasa, R. M.; Romo, D.; Stirling, D. J.; Blunt, J. W.; Munro, M. H. G., Structural and Synthetic Studies of the Pateamines: Synthesis and Absolute Configuration of the Hydroxydienoate Fragment. Tetrahedron Lett. 1995, 36 (30), 5307-5310.

11. Romo, D.; Rzasa, R. M.; Shea, H. A.; Park, K.; Langenhan, J. M.; Sun, L.; Akhiezer, A.; Liu, J. O., Total Synthesis and Immunosuppressive Activity of (-)-Pateamine A and Related Compounds: Implementation of a $\beta$ Lactam-Based Macrocyclization. J. Am. Chem. Soc. 1998, 120 (47), 12237-12254.

12. Clardy, J., Stopping Trouble Before It Starts. ACS Chem. Biol. 2006, 1 (1), 17-19.

13. Remuiñán, M. J.; Pattenden, G., Total Synthesis of (-)-Pateamine, a Novel Polyene Bis-Macrolide with Immunosuppressive Activity From the Sponge Mycale sp. Tetrahedron Lett. 2000, 41 (38), 7367-7371.

14. Romo, D.; Choi, N. S.; Li, S.; Buchler, I.; Shi, Z.; Liu, J. O., Evidence for Separate Binding and Scaffolding Domains in the Immunosuppressive and Antitumor Marine Natural Product, Pateamine A: Design, Synthesis, and Activity Studies Leading to a Potent Simplified Derivative. J. Am. Chem. Soc. 2004, 126 (34), 10582-10588.

15. Cumming, H., Design and Synthesis of Simplified Analogues of Pateamine A. Ph.D. Thesis, Victoria University of Wellington, 2013.

16. Critcher, D. J.; Pattenden, G., Synthetic Studies Towards Pateamine, a Novel Thiazole-Based 19-Membered Bis-Lactone from Mycale sp. Tetrahedron Lett. 1996, 37 (50), 9107-9110.

17. Rand, C. L.; Van Horn, D. E.; Moore, M. W.; Negishi, E., A Versatile and Selective Route to Difunctional Trisubstituted (E)-alkene Synthons via Zirconium-Catalyzed Carboalumination of Alkynes. J. Org. Chem. 1981, 46 (20), 4093-4096.

18. Stille, J. K.; Groh, B. L., Stereospecific Cross-coupling of Vinyl Halides with Vinyl Tin Reagents Catalyzed by Palladium. J. Am. Chem. Soc. 1987, 109 (3), 813-817. 
19. Takai, K.; Nitta, K.; Utimoto, K., Simple and Selective Method for Aldehydes (RCHO). (E)-haloalkenes $(\mathrm{RCH}: \mathrm{CHX})$ Conversion by means of a Haloform-chromous Chloride System. J. Am. Chem. Soc. 1986, 108 (23), 74087410 .

20. Jencks, W. P.; Regenstein, J., lonization Constants of Acids and Bases. In Handbook of Biochemistry and Molecular Biology, Fourth Edition, CRC Press: 2010; pp 595-635.

21. Matthews, J. H.; Maass, D. R.; Northcote, P. T.; Atkinson, P. H.; Teesdale-Spittle, P. H., The Cellular Target Specificity of Pateamine A. Zeitschrift Fur Naturforschung 2013, 68c (9-10), 406-415.

22. Katritzky, A. R.; Ogretir, C.; Tarhan, H. O.; Dou, H. M.; Metzger, J. V., The Kinetics and Mechanism of the Electrophilic Substitution of Heteroaromatic Compounds. Part XLII. The Nitration of Thiazoles and Thiazolones. J. Chem. Soc., Perkin Trans. 2 1975, (14), 1614-1620.

23. Bordeleau, M. E.; Matthews, J.; Wojnar, J. M.; Lindqvist, L.; Novac, O.; Jankowsky, E.; Sonenberg, N.; Northcote, P.; Teesdale-Spittle, P.; Pelletier, J., Stimulation of Mammalian Translation Initiation Factor elF4A Activity by a Small Molecule Inhibitor of Eukaryotic Translation. Proc Natl Acad Sci U.S.A 2005, 102 (30), 10460-10465.

24. Low, W. K.; Dang, Y.; Schneider-Poetsch, T.; Shi, Z.; Choi, N. S.; Merrick, W. C.; Romo, D.; Liu, J. O., Inhibition of Eukaryotic Translation Initiation by the Marine Natural Product Pateamine A. Mol. Cell 2005, 20 (5), 70922.

25. Bordeleau, M. E.; Cencic, R.; Lindqvist, L.; Oberer, M.; Northcote, P.; Wagner, G.; Pelletier, J., RNAMediated Sequestration of the RNA Helicase elF4A by Pateamine A Inhibits Translation Initiation. Chem. Biol. 2006, $13(12), 1287-1295$.

26. Bordeleau, M.-E.; Mori, A.; Oberer, M.; Lindqvist, L.; Chard, L. S.; Higa, T.; Belsham, G. J.; Wagner, G.; Tanaka, J.; Pelletier, J., Functional Characterization of IRESes by an Inhibitor of the RNA Helicase elF4A. Nat. Chem. Biol. 2006, 2 (4), 213-220.

27. Bono, F.; Ebert, J.; Lorentzen, E.; Conti, E., The Crystal Structure of the Exon Junction Complex Reveals How It Maintains a Stable Grip on mRNA. Cell 2006, 126 (4), 713-725.

28. Andersen, C. B. F.; Ballut, L.; Johansen, J. S.; Chamieh, H.; Nielsen, K. H.; Oliveira, C. L. P.; Pedersen, J. S.; Séraphin, B.; Hir, H. L.; Andersen, G. R., Structure of the Exon Junction Core Complex with a Trapped DEAD-Box ATPase Bound to RNA. Science 2006, 313 (5795), 1968-1972.

29. Andreou, A. Z.; Klostermeier, D., The DEAD-box Helicase elF4A: Paradigm or the Odd One Out? RNA Biol. 2013, $10(1), 19-32$.

30. Di Marco, S.; Cammas, A.; Lian, X. J.; Kovacs, E. N.; Ma, J. F.; Hall, D. T.; Mazroui, R.; Richardson, J.; Pelletier, J.; Gallouzi, I. E., The Translation Inhibitor Pateamine A Prevents Cachexia-Induced Muscle Wasting in Mice. Nature Communications 2012, 3, 896.

31. Dang, Y.; Kedersha, N.; Low, W. K.; Romo, D.; Gorospe, M.; Kaufman, R.; Anderson, P.; Liu, J. O., Eukaryotic Initiation Factor $2 \alpha$-Independent Pathway of Stress Granule Induction by the Natural Product Pateamine A. J. Biol. Chem. 2006, 281 (43), 32870-32878.

32. Kedersha, N.; Anderson, P., Stress Granules: Sites of mRNA Triage that Regulate mRNA Stability and Translatability. Biochem. Soc. Trans. 2002, 30 (6), 963-969.

33. Anderson, P.; Kedersha, N., RNA granules. J. Cell Biol. 2006, 172 (6), 803-808.

34. Buchan, J. R.; Parker, R., Eukaryotic Stress Granules: The Ins and Out of Translation. Mol. Cell 2009, 36 (6), 932-941.

35. Low, W.-K.; Dang, Y.; Bhat, S.; Romo, D.; Liu, J. O., Substrate-Dependent Targeting of Eukaryotic Translation Initiation Factor 4A by Pateamine A: Negation of Domain-Linker Regulation of Activity. Chem. Biol. 2007, 14 (6), 715-727.

36. Hood, K. A.; West, L. M.; Northcote, P. T.; Berridge, M. V.; Miller, J. H., Induction of Apoptosis by the Marine Sponge (Mycale) Metabolites, Mycalamide A and Pateamine. Apoptosis 2001, 6 (3), $207-219$. 
37. Bottley, A.; Phillips, N. M.; Webb, T. E.; Willis, A. E.; Spriggs, K. A., elF4A Inhibition Allows Translational Regulation of mRNAs Encoding Proteins Involved in Alzheimer's Disease. PLoS One 2010, 5 (9), e13030.

38. Khaperskyy, D. A.; Emara, M. M.; Johnston, B. P.; Anderson, P.; Hatchette, T. F.; McCormick, C., Influenza A Virus Host Shutoff Disables Antiviral Stress-Induced Translation Arrest. PLoS Pathog. 2014, 10 (7), e1004217.

39. Small, S. A.; Duff, K., Linking A $\beta$ and Tau in Late-Onset Alzheimer's Disease: A Dual Pathway Hypothesis. Neuron 2008, 60 (4), 534-542.

40. Yan, P.; Bero, A. W.; Cirrito, J. R.; Xiao, Q.; Hu, X.; Wang, Y.; Gonzales, E.; Holtzman, D. M.; Lee, J.-M., Characterizing the Appearance and Growth of Amyloid Plaques in APP/PS1 Mice. J. Neurosci. 2009, 29 (34), 1070610714.

41. Hall, D. T.; Ma, J. F.; Di Marco, S.; Gallouzi, I.-E., Inducible Nitric Oxide Synthase (iNOS) in Muscle Wasting Syndrome, Sarcopenia, and Cachexia. Aging (Milano) 2011, 3 (8), 702-715.

42. Tisdale, M. J., Mechanisms of Cancer Cachexia. Physiol. Rev. 2009, 89 (2), 381-410.

43. Guttridge, D. C.; Mayo, M. W.; Madrid, L. V.; Wang, C.-Y.; Baldwin Jr., A. S., NF-kB-Induced Loss of MyoD Messenger RNA: Possible Role in Muscle Decay and Cachexia. Science 2000, 289 (5488), 2363-2366.

44. Buck, M.; Chojkier, M., Muscle Wasting and Dedifferentiation Induced by Oxidative Stress in a Murine Model of Cachexia is Prevented by Inhibitors of Nitric Oxide Synthesis and Antioxidants. EMBO 1996, 15 (8), $1753-$ 1765.

45. Khaperskyy, D. A.; Hatchette, T. F.; McCormick, C., Influenza A Virus Inhibits Cytoplasmic Stress Granule Formation. FASEB J. 2012, 26 (4), 1629-1639.

46. Tanino, K.; Onuki, K.; Asano, K.; Miyashita, M.; Nakamura, T.; Takahashi, Y.; Kuwajima, I., Total Synthesis of Ingenol. J. Am. Chem. Soc. 2003, 125 (6), 1498-1500.

47. Smith, A. B.; Bosanac, T.; Basu, K., Evolution of the Total Synthesis of (-)-Okilactomycin Exploiting a Tandem Oxy-Cope Rearrangement/Oxidation, the Petasis-Ferrier Union/Rearrangement and Ring Closing Metathesis. J. Am. Chem. Soc. 2009, 131 (6), 2348-2358.

48. Armarego, W. L. F.; Chai, C., Chapter 4 - Purification of Organic Chemicals. In Purification of Laboratory Chemicals (Seventh Edition), Butterworth-Heinemann: Boston, 2013; pp 111-112.

49. Martinez-Solorio, D.; Jennings, M. P., Chemoselective TBS Deprotection of Primary Alcohols by Means of Pyridinium Tribromide ( $\mathrm{Py} \cdot \mathrm{Br} 3)$ in $\mathrm{MeOH}$. Tetrahedron Lett. 2008, 49 (35), 5175-5178.

50. Katritzky, A. R.; Pilarski, B.; Urogdi, L., Efficient Conversion of Nitriles to Amides with Basic Hydrogen Peroxide in Dimethyl Sulfoxide. Synthesis 1989, (12), 949-950.

51. Durand, P.; Richard, P.; Renaut, P., (-)-15-Deoxyspergualin: A New and Efficient Enantioselective Synthesis Which Allows the Definitive Assignment of the Absolute Configuration. J. Org. Chem. 1998, 63 (26), 9723-9727.

52. Helal, M. H.; El-Awdan, S. A.; Salem, M. A.; Abd-elaziz, T. A.; Moahamed, Y. A.; El-Sherif, A. A.; Mohamed, G. A. M., Synthesis, Biological Evaluation and Molecular Modeling of Novel Series of Pyridine Derivatives as Anticancer, Anti-inflammatory and Analgesic Agents. Spectrochim. Acta Mol. Biomol. Spectrosc. 2015, 135, 764-773.

53. Woo, S. K.; Lee, E., Polycavernoside A: The Prins Macrocyclization Approach. J. Am. Chem. Soc. 2010, 132 (13), 4564-4565.

54. Kukushkin, V. Y.; Pombeiro, A. J. L., Metal-mediated and Metal-catalyzed Hydrolysis of Nitriles. Inorg. Chim. Acta 2005, $358(1), 1-21$.

55. Xuehe, L.; Gibb, B. C., Towards Multi-generation Assemblies with Tetraphenylmethane Subunits. Supramol. Chem. 2003, $15(7 / 8), 495-503$.

56. Ishiwata, Y.; Togo, H., Facile Preparation of Thiazoles from 1H-1-(1'-Alkynyl)-5-methyl-1,2,3benziodoxathiole 3,3-Dioxide with Thioamides. Synlett 2008, (17), 2637-2641. 
57. He, W.; Xie, L.; Xu, Y.; Xiang, J.; Zhang, L., Electrophilicity of $[\alpha]$-oxo Gold Carbene Intermediates: Halogen Abstractions from Halogenated Solvents Leading to the Formation of Chloro/bromomethyl Ketones. Org. Biomol. Chem. 2012, 10 (16), 3168-3171.

58. Wu, G.; Zheng, R.; Nelson, J.; Zhang, L., One-Step Synthesis of Methanesulfonyloxymethyl Ketones via Gold-Catalyzed Oxidation of Terminal Alkynes: A Combination of Ligand and Counter Anion Enables High Efficiency and a One-Pot Synthesis of 2,4-Disubstituted Thiazoles. Adv. Synth. Catal. 2014, 356 (6), 1229-1234.

59. Luo, Y.; Ji, K.; Li, Y.; Zhang, L., Tempering the Reactivities of Postulated $\alpha$-Oxo Gold Carbenes Using Bidentate Ligands: Implication of Tricoordinated Gold Intermediates and the Development of an Expedient Bimolecular Assembly of 2,4-Disubstituted Oxazoles. J. Am. Chem. Soc. 2012, 134 (42), 17412-17415.

60. Xie, L.; Liang, Z.; Yan, D.; He, W.; Xiang, J., Gold-Catalyzed Intermolecular Oxidation of Terminal Alkynes: Simple and Efficient Synthesis of $\alpha$-Mesyloxy Ketones. Synlett 2013, 24 (14), 1809-1812.

61. Bering, L.; Antonchick, A. P., Regioselective Metal-Free Cross-Coupling of Quinoline N-Oxides with Boronic Acids. Org. Lett. 2015, 17 (12), 3134-3137.

62. Kumar, V. P.; Narender, M.; Sridhar, R.; Nageswar, Y. V. D.; Rama Rao, K., Synthesis of Thiazoles and Aminothiazoles from $\beta$-Keto Tosylates under Supramolecular Catalysis in the Presence of $\beta$-Cyclodextrin in Water. Synth. Commun. 2007, 37 (24), 4331-4336.

63. Kumar, D.; Kumar, N. M.; Patel, G.; Gupta, S.; Varma, R. S., A Facile and Eco-friendly Synthesis of Diarylthiazoles and Diarylimidazoles in Water. Tetrahedron Lett. 2011, 52 (16), 1983-1986.

64. Hou, R.-S.; Wanga, H.-M.; Tsai, H.-H.; Chen, L.-C., Synthesis of 2-Phenylthiazoles from $\alpha$-Tosyloxyketones and Thiobenzamide in [Bmim][PF6] lonic Liquid at Ambient Temperature. J. Chin. Chem. Soc. 2006, 53 (4), 863-866.

65. Fleming, F. F.; Wang, Q.; Steward, O. W., Hydroxylated $\alpha, \beta$-Unsaturated Nitriles: Stereoselective Synthesis. J. Org. Chem. 2001, 66 (6), 2171-2174.

66. Mosmann, T., Rapid Colorimetric Assay for Cellular Growth and Survival: Application to Proliferation and Cytotoxicity Assays. J. Immunol. Methods 1983, 65 (1), 55-63.

67. Liu, L.; Floreancig, P. E., 2,3-Dichloro-5,6-dicyano-1,4-benzoquinone-Catalyzed Reactions Employing $\mathrm{MnO}_{2}$ as a Stoichiometric Oxidant. Org. Lett. 2010, 12 (20), 4686-4689.

68. Arikan, F.; Li, J.; Menche, D., Diastereodivergent Aldol Reactions of $\beta$-Alkoxy Ethyl Ketones: Modular Access to $(1,4)$-syn and -anti Polypropionates. Org. Lett. 2008, 10 (16), 3521-3524.

69. Mohapatra, D. K.; Das, P. P.; Sai Reddy, D.; Yadav, J. S., First Total Syntheses and Absolute Configuration of Rugulactone and 6(R)-(4'-oxopent-2'-enyl)-5,6-dihydro-2H-pyran-2-one. Tetrahedron Lett. 2009, 50 (43), 5941-5944.

70. Böse, D.; Fernández, E.; Pietruszka, J., Stereoselective Synthesis of Both Enantiomers of Rugulactone. J. Org. Chem. 2011, 76 (9), 3463-3469.

71. Keck, G. E.; Covel, J. A.; Schiff, T.; Yu, T., Pyran Annulation: Asymmetric Synthesis of 2,6-Disubstituted-4methylene Tetrahydropyrans. Org. Lett. 2002, 4 (7), 1189-1192.

72. Mahammed, K. A.; Jayashankara, V. P.; Premsai Rai, N.; Mohana Raju, K.; Arunachalam, P. N., A Mild and Versatile Synthesis of Thioamides. Synlett 2009, 2009 (14), 2338-2340.

73. Field, J. J.; Singh, A. J.; Kanakkanthara, A.; Halafihi, T. i.; Northcote, P. T.; Miller, J. H., MicrotubuleStabilizing Activity of Zampanolide, a Potent Macrolide Isolated from the Tongan Marine Sponge Cacospongia mycofijiensis. J. Med. Chem. 2009, 52 (22), 7328-7332. 